MÓNICA BAPTISTE RESTREPO

ESTUDO DO EFEITO DE AUTORREPARAÇÃO NOS REVESTIMENTOS ADITIVADOS COM MICROCÁPSULAS CONTENDO ÓLEO DE LINHAÇA 
MÓNICA BAPTISTE RESTREPO

\section{ESTUDO DO EFEITO DE AUTORREPARAÇÃO NOS REVESTIMENTOS ADITIVADOS COM MICROCÁPSULAS CONTENDO ÓLEO DE LINHAÇA}

Dissertação apresentada à Escola Politécnica da Universidade de São Paulo para obtenção do título de Mestre em Engenharia

Área de Concentração: Engenharia Química

Orientador: Prof. Dra. Idalina Vieira Aoki

São Paulo

2012 
MÓNICA BAPTISTE RESTREPO

ESTUDO DO EFEITO DE AUTORREPARAÇÃO NOS REVESTIMENTOS ADITIVADOS COM MICROCÁPSULAS CONTENDO ÓLEO DE LINHAÇA

Dissertação apresentada à Escola Politécnica da Universidade de São Paulo para obtenção

do título de Mestre em Engenharia

São Paulo 
Este exemplar foi revisado e alterado em relação à versão original, sob responsabilidade única do autor e com a anuência do orientador.

São Paulo, 19 de dezembro de 2012.

Assinatura do autor:

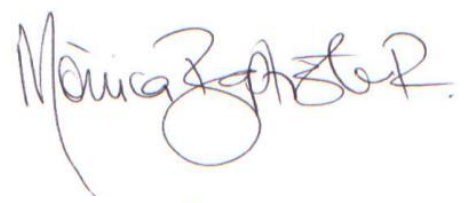

Assinatura do orientador:

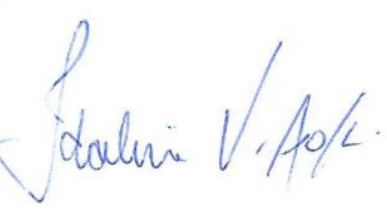

\section{FICHA CATALOGRÁFICA}

\section{Baptiste Restrepo, Mônica}

Estudo do efeito de autorreparação nos revestimentos aditivados com microcápsulas contendo óleo de linhaça / $M$.

Baptiste Restrepo. -- ed. rev. --- São Paulo, 2012.

$77 \mathrm{p}$.

Dissertação (Mestrado) - Escola Politécnica da Universidade de São Paulo. Departamento de Engenharia Química.

1. Revestimentos 2. Autorreparadores I. Universidade de São Paulo. Escola Politécnica. Departamento de Engenharia Química II. t. 


\section{DEDICATÓRIA}

A Dios: Por darme la fuerza para conseguir este logro y por mantenerme firme en todo momento

A mi Papá, mi Mamá, mi Hermano y Tábata: el apoyo de ustedes, la paciencia y las risas en medio del estrés a pesar de la distancia, ustedes creyeron en mí en todo momento y eso fue mi motor principal para llegar a donde estoy. Los amo familia!

A meus amigos do Brasil: vocês complementaram minha vida em São Paulo. Tornaram-se minha família e por isto e muito mais estou muito agradecida e dedico este trabalho a vocês e os levo comigo sempre.

Ao Brasil: País abençoado por Deus e bonito por natureza.

O verdadeiro valor das coisas você descobre quando luta por 
elas, sendo medido pelo esforço que você faz para alcançá-las"

Carlos Alexandre Cardoso

\section{AGRADECIMENTOS}

À Professora Idalina, pela orientação, paciência e bons conselhos, o crescimento e aprendizado devo a você. A exigência me ensinou de quanto eu sou capaz e quanto além eu posso chegar. Com muito carinho estarei sempre agradecida por tudo.

Teresa: Tere os nossos papos no laboratório acalmaram meu stress. Obrigada mesmo por evitar que eu perdesse meus dedos lixando aquelas peças enormes e por não me dar broncas pelas melecas que deixei no lab.

Rocio, Vera, Fernando, Ju Passadore: apoio incondicional! Gracias por su increíble amistad, por los momentos compartidos en el lab durante la elaboración de este proyecto.., viva o Bloco 18! e obrigada pela força até com o português!

A meus amigos: sempre estiveram me mandando energia positiva e me dando ânimo para nunca desistir... um caminho longo que sem vocês não sei exatamente qual teria sido o rumo. Obrigada!

À USP: pela oportunidade de ser parte da melhor universidade do mundo. 
A CAPES, pelo apoio económico recebido durante o tempo que estive como bolsista.

\section{RESUMO}

BAPTISTE, Mónica. Estudo do efeito de autorreparação nos revestimentos aditivados com microcápsulas contendo óleo de linhaça . 2012. Dissertação (Mestrado). Escola Politécnica, Universidade de São Paulo, São Paulo, 2012

O objetivo deste trabalho foi a preparação de um revestimento inteligente com resina epóxi, capaz de autorreparar-se quando o sofre um defeito mecânico. A autorreparação é possibilitada pela presença de microcápsulas, dispersas na resina (revestimento de epóxi sem pigmentos) e que contêm no seu núcleo o agente de autorreparação, o óleo de linhaça. Estas cápsulas foram preparadas por uma emulsão de óleo de linhaça em água para formar micelas e sobre estas uma parede ou casca exterior de poliuréiaformaldeído. Para a avaliação da resistência à corrosão e do efeito de autorreparação do revestimento, chapas de aço carbono foram revestidas e avaliadas pela técnica de espectroscopia de impedância eletroquímica (EIE) em $0.1 \mathrm{molL}^{-1} 1 \mathrm{NaCl}$ e também foram avaliadas pelo teste acelerado de corrosão em câmara de névoa salina (SSC). Após a cura do revestimento aditivado com as microcápsulas, aplicado sobre placas de aço carbono, as medidas eletroquímicas de impedância foram realizadas em corpos de prova com um defeito mecânico provocado de forma controlada e reprodutível. Uma célula de três eletrodos foi utilizada. Estas medidasforam efetuadas após 0h, 24h e 48h da execução da incisão ou defeito mecânico. Para comparação, as mesmas medidas foram realizadas com as placas pintadas com o revestimento não-aditivado, com a mesma espessura total de $120 \mu \mathrm{m}$. Os resultados mostraram que as cápsulas foram quebradas e se liberou o óleo de linhaça, reparando a área da incisão o defeito após pelo menos 24 horas de exposição natural ao ar ambiente. Verificou-se que para as placas revestidas sem defeito, os valores de | Z | mantiveram-se elevados. No entanto, o revestimento sem as microcápsulas, após 24 horas, mostrou uma diminuição considerável no valor de módulo de impedância, $|Z|$. Assim, usando a ténica de EIE foi possível avaliar quantitativamente o mecanismo de autorreparação do revestimento aditivado com microcápsulas que contêm óleo de linhaça. Os ensaios acelerados de corrosão (SSC) mostraram resultados em estreita concordância com os obtidos por EIE. 
Palavras-chave: Autorreparação, microencapsulação, revestimentos inteligentes, óleo de linhaça, EIE.

\section{ABSTRACT}

BAPTISTE, Mónica. Study of the self-healing effect of coatings additivated with microcapsules containing linseed oil. 2012. Dissertation (Master Degree). Escola Politécnica, Universidade de São Paulo, São Paulo, 2012

The aim of this work was the preparation of a smart coating with epoxy resin which is able to repair itself (self-healing effect) after suffering a mechanical defect. Self-healing is possible due to the presence of microcapsules, dispersed in the resin (clear type epoxy coating) and contain in their core the self-healing agent, the linseed oil. These capsules were prepared in an emulsion of linseed oil in water to form micelles and an outer skin or wall of poly(urea-formaldehyde) was formed. For the corrosion resistance and the self-healing effect evaluation of the coating, carbon steel plates were coated and tested by electrochemical impedance spectroscopy technique (EIS) in $0.1 \mathrm{molL}^{-1}$ $\mathrm{NaCl}$ solution and by accelerated corrosion test in salt spray chamber (SSC). After curing of the capsules additivated epoxy based clear coating applied on carbon steel plates, electrochemical impedance measurements were performed on plates with a controlled and reproducible mechanical defect. A three-electrode electrochemical cell was used. These measurements were performed after $0 \mathrm{~h}, 24 \mathrm{~h}$ and $48 \mathrm{~h}$ of making the incision or mechanical defect. For comparison, the same measurements were performed with the plates painted with a non- capsules additivated clear coating of the same total thickness of $120 \mu \mathrm{m}$. The results showed that the capsules were broken and released the linseed oil, which indeed have repaired the incision area after at least 24 hours of natural air aging. It was found that for the plates coated without a defect, the values of impedance modulus, $|Z|$, remained high. However, the coating without the capsules after 24 hours, showed a considerable decrease in |Z|. So, using EIS it was possible to quantitatively assess the mechanism of self-healing of the additivated coating using microcapsules containing linseed oil. The SSC accelerated corrosion tests showed results in close agreement with those obtained by EIS.

Keywords: Self-healing, microencapsulation, smart coatings, linseed oil, EIS, SSC test. 


\section{LISTA DE ILUSTRAÇÕES}

Figura 1 - Sistema pintura para a proteção de metais com uso de pré-tratamento.

Figura 2 - Esquema do processo de autorreparação conferido por microcápsulas numa tinta aplicada sobre substrato metálico.

10

Figura 3 - Micela precursora para a formação das microcápsulas .

Figura 4- llustração da formação de microcápsulas pelo método de co-extrusão

Figura 5- Imagens das microcápsulas vistas ao microscópio ótico(Ting et al., 2010)

Figura 6- Imagem obtida por MEV de uma microcápsula de uréia-formaldeído contendo óleo de linhaça (a) e gráfico de distribuição de tamanhos de partículas (b) - (Dhirendra et al., 2008).

Figura 7- Diagrama de Bode para aço HDG revestido com resina aditivada com nanoreservatórios contendo 2-mercaptobenzotiazol, em solução de $\mathrm{NaCl}$ $5 \mathrm{mM}$ e com defeito no revestimento. -preto: seis dias, vermelho: sete dias, azul: 10 dias- (Kartsonakis, et al 2011)

Figura 8- Diagramas de Bode do aço revestido com resina aditivada com microcápsulas contendo óleo de tung imersa durante (a) um dia, (b) sete dias, (c) 14 dias em solução aquosa de $\mathrm{NaCl} 3.5 \%$ (Samadzadeh, et al 2011

Figura 9 - Resposta comparativa da impedância para aço revestido com aditivação (esferas cheias) e sem aditivação (esferas vazias), em solução de $\mathrm{NaCl}$ 0,5 $M$, com defeito feito manualmente (a) resina epóxi pura, (b) resina contendo $2 \%$ argila modificada [Oliver et Al 2010]

Figura 10 - Representação da resposta obtida pela LEIS para aço zincado em solução de $\mathrm{NaCl} 0.001 \mathrm{M}$ para 1 hora de imersão $(\mathrm{a}, \mathrm{c})$ e 12 horas de imersão (b, d) quando a resina epóxi contem argila modificada com inibidor $(a, b)$ e quando se usa resina epóxi pura (c, d) modificada [Oliver, et Al 2010]

Figura 11- Diferentes tipos de defeitos que podem se formar no revestimento (Blaiszik, et al., 2010) 
Figura 12- Evolução da corrosão por exposição na câmara de névoa salina para revestimento aditivado com microcápsulas contendo óleo de linhaça(Dhirendra et al., 2008);

Figura 13- Representação do óleo de linhaça.

33

Figura 14 - Fluxograma do mecanismo.de oxidação do óleo de linhaça para a formação de filme

Figura 15 - llustração do mecanismo para a formação de estruturas reticuladas e outras estruturas tais como álcoois, o diferentes grupos carbonilos. [Chiantore e Lazzari (1999)]

Figura 16- Processo de preparação das microcápsulas de uréia-formaldeído contendo óleo de linhaça pelo método I

34

35

39

Figura 17- Processo de preparação das microcápsulas de uréia-formaldeído contendo óleo de linhaça pelo métodoll

40

Figura 18- Suspensão de microcápsulas usada no processo de lavagem e filtração a vácuo.

41

Figura 19- Indentador de durômetro de plásticos marcando carga de $50 \mathrm{~N}$ durante execução do defeito.

45

Figura 20-Montagem da célula com três eletrodos para realização de medidas de EIE.

Figura 21- Tendência da variação da estabilidade de uma emulsão óleo-em-água com a quantidade e tipo de surfactante.

Figura 22- Imagens obtidas ao microscópio ótico depois de (a) uma hora , (b) duas horas, (c) três horas e (d) quatro horas de polimerização.

Figura 23- Micrografias obtidas por MEV com imagem de elétrons secundários das microcápsulas obtidas usando diferentes aumentos. (a) pequena microcápsula contendo óleo de linhaçã. (b) microcápsula quebrada. (c) grupo de microcápsulas e material restante da polimerização. (d) microcápsula contendo óleo de linhaça, com parede bem definida.

Figura 24-Aspecto de placa de aço carbono com uma demão de "clear" aplicado por "dip coating"aditivado com microcápsulas mal dispersas

Figura 25-Imagem para a comparação da dispersão de microcápsulas em diferentes solventes com e sem o uso do emulsificante Silwet 7607

Figura 26- Resultado da aplicação do "clear" aditivado com as microcápsulas usando pincel

Figura 27- Resultado da aplicação do "clear" aditivado com microcápsulas usando o processo de "dip coating"

Figura 28- Extensor de tinta para quatro espessuras. (b) Resultado da aplicação do "clear" usando extensor formador de uma película úmida com espessura de $120 \mu \mathrm{m}$.

Figura 29- Aspecto do defeito realizado com indentador de prova de impacto 
Figura 30- Aspecto do defeito executado com um durômetro para plásticos.

Figura 31- (a)Diagramas de Nyquist e (b) Diagrama de Bode para um sistema de aço

62 carbono revestido com clear aditivado com $5 \%$ de microcápsulas, contendo óleo de linhaça para diferentes tempos após confecção do defeito, em $\mathrm{NaCl} 0,1 \mathrm{M}$.

Figura 32- Diagramas de Bode para um sistema de aço revestido com revestimento tipo "clear" de epóxi aditivado com 10\% em massa de microcápsulas contendo óleo de linhaça após diferentes tempos depois de realizado o defeito, em $\mathrm{NaCl} 0,1 \mathrm{M}$.

Figura 33- Diagramas de Bode de $\log |\mathrm{Z}| \times \log f$ para um sistema de aço carbono revestido com "clear" aditivado ou não com $10 \%$ de microcápsulas, contendo óleo de linhaça após $24 \mathrm{~h}$ da confecção do defeito, e imerso em $\mathrm{NaCl} 0,1 \mathrm{M}$

Figura 34- Comportamento do módulo de impedância com o tempo para corpos de prova de aço carbono revestidos com resina epóxi aditivada com microcápsulas contendo óleo de linhaça como agente autorreparador e resina epóxi sem aditivar imersos em solução de $\mathrm{NaCl} 0,1 \mathrm{M}$ apos do defeito no revestimento e expostos ao ar por 0, 24 e 48 horas.

Figura 35- Aparência dos painéis revestidos com resina epóxi (a) referência negativa não aditivada- e painéis revestidos com resina aditivada com $10 \%$ em massa de microcápsulas contendo óleo de linhaça, com um tempo de confecção do defeito de (b) 0 horas, (c) 24 horas, (d) 48 horas, (e) 72 horas. Tempo de permanência dentro da câmara de névoa salina: um dia.

Figura 36- Aparência dos painéis revestidos após uma semana de exposição à névoa salina (a) com resina epóxi sem aditivar e colocada dentro da câmara de névoa salina após 0 horas da confecção do defeito, (b) com resina epóxi sem aditivar e 24 horas da confecção do defeito, (c) com resina epóxi aditivada com $10 \%$ em massa de microcápsulas e 0 horas da confecção do defeito, (d) com resina epóxi aditivada com 10\% em massa de microcápsulas e 24 horas da confecção do defeito.

Tabela 1- Métodos para realizar a microencapsulação

Tabela 2- Circuitos equivalentes para a avaliação da degradação do aço carbono revestido e com diferentes pretratamentos. (os números da tabela representam o número de vezes que foi utilizado o circuito para o ajuste durante o teste). [Di Sarli et Al. (1998)] 
Tabela 3- Características químicas e mecânicas do aço carbono IF

Tabela 4-Dispersão de microcápsulas em diferentes solventes com e sem o uso do emulsificante Silwet 7607

\section{SUMÁRIO}

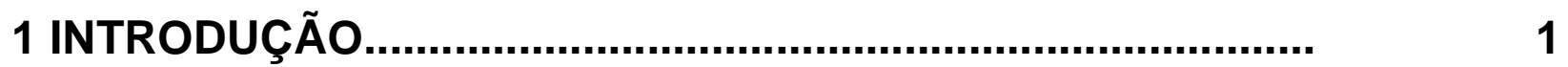

2 REVISÃO DA LITERATURA...................................................

2.1 IMPORTÂNCIA DO ESTUDO DE CORROSÃO DE METAIS............. 2

2.2 MÉTODOS DE PROTEÇÃO DE METAIS CONTRA CORROSÃO...... 4

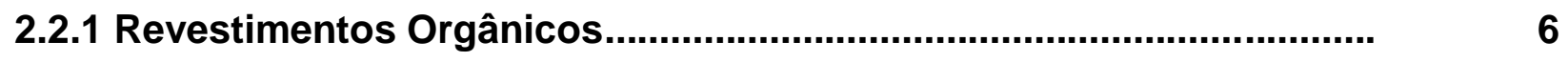

2.2.2 Pré-tratamentos............................................................................

2.2.3 Revestimentos "inteligentes" de autorreparação................................ 8

2.3 PROTEÇÃO POR EFEITO DE AUTORREPARAÇÃO OU "SELF-

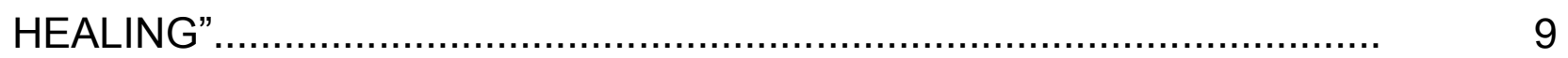

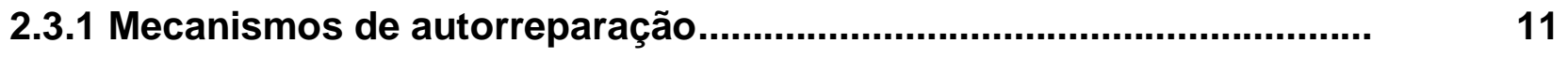

2.3.2 Processo para a microencapsulação......................................................

2.4 TÉCNICAS DE VALIDAÇÃO DO PROCESSO DE

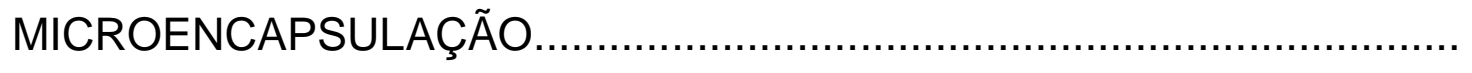

2.5 TÉCNICAS PARA AVALIAR O EFEITO DE AUTORREPARAÇÃO OU DE "SELF-HEAKING"

2.5.1 Técnica de espectroscopia de impedância eletroquímica..................... 19

2.6 INFLUÊNCIA DO TIPO DE DEFEITOS PROVOCADOS NOS 28 
REVESTIMENTOS DE AUTORREPARAÇÃO.

2.7. ENSAIOS ACELERADOS DE CORROSÃO: CÂMARA DE NÉVOA SALINA..

2.8 FORMAÇÃO DO FILME AUTORREPARADOR A PARTIR DE ÓLEO DE LINHAÇA.

3 MATERIAIS E MÉTODOS......................................................

3.1 SUBSTRATO UTILIZADO …………………………………….......... 36

3.2 CARACTERÍSTICAS DO ÓLEO DE LINHAÇA UTILIZADO COMO AGENTE DE AUTORREPARAÇÃO........................................................ 37

3.3 TRATAMENTO DA SUPERFÍCIE DO SUBSTRATO............................ 37

3.4 PREPARAÇÃO DAS MICROCÁPSULAS .......................................... 38

3.4.1 Preparação da emulsão óleo de linhaça em solução aquosa............... $\quad 38$

3.4.2 Filtração sob vácuo..........................................................................

3.5 CARACTERIZAÇÃO DAS MICROCÁPSULAS................................... 41

3.5.1 Avaliação das microcápsulas ao microscópio ótico.............................. 41

3.5.2 Caracterização das Microcápsulas por MEV......................................... $\quad 41$

3.6 PREPARAÇÃO DO REVESTIMENTO TIPO "CLEAR" A BASE DE RESINA EPÓXI......................................................................... 42

3.6.1 Preparação do "clear" sem aditivação................................................... 42

3.6.2 Preparação do "clear" aditivado com $5 \%$ e $10 \%$ em massa de microcápsulas.

3.7 TÉCNICAS PARA A APLICAÇÃO E AVALIAÇÃO DO REVESTIMENTO TIPO “CLEAR”........................................................

3.7.1 Mecanismos de aplicação do revestimento.............................................. 44 
3.7.2 Confecção de defeito no revestimento.

3.7.3 Avaliação do efeito autorreparador (self-healing) do revestimento tipo "clear" pela técnica de espectroscopia de impedância eletroquímica...

3.7.4 Avaliação do efeito autorreparador (self-healing) do revestimento tipo "clear" utilizando ensaios na câmara de névoa salina.............................

4 RESULTADOS E DISCUSSÃO...................................................

4.1 OBTENÇÃO DE MICROCÁPSULAS ............................................. 48

4.1.1 Otimização do processo de preparação das microcápsulas.................. 48

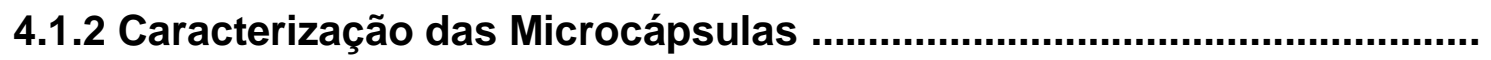

4.2 DISCUSSÕES SOBRE O APRIMORAMENTO DA PREPARAÇÃO DO REVESTIMENTO TIPO "CLEAR"

4.3 DISCUSSÕES SOBRE O APRIMORAMENTO DA PREPARAÇÃO DOS CORPOS-DE-PROVA REVESTIDOS.

4.3.1 Dispersão das microcápsulas nos diluentes do revestimento tipo "clear".

4.3.2 Métodos de aplicação do revestimento tipo "clear".

4.4 AVALIAÇÃO DO EFEITO "SELF-HEALING" NOS CORPOS DE PROVA REVESTIDOS.

4.4.1 Influência da forma de execução do defeito no revestimento................

4.4.2 Resultados de EIE para avaliar o efeito "Self-healing"

4.4.2.1 Resultados de EIE para corpo de prova revestido com revestimento clear aditivado com $5 \%$ em massa de microcápsulas.

4.4.2.2 Resultados de EIE para corpo de prova revestido com revestimento clear aditivado com $10 \%$ em massa de microcápsulas.

4.6 AVALIAÇÃO DO EFEITO DE "SELF HEALING" COM O ENSAIO 
ACELERADO DE CORROSÃO EM CÂMARA DE NÉVOA SALINA............

5 CONCLUSÕES........................................................................ 69

6 SUGESTÕES PARA TRABALHOS FUTUROS............................... 71

7 REFERÊNCIAS BILBIOGRÁFICAS................................................ 


\section{INTRODUÇÃO}

A corrosão é um fenômeno natural dos metais que ocorre de maneira espontânea e causa, além de impactos ambientais, um custo econômico importante. Às vezes as pessoas têm a idéia de que nada é possível fazer contra a corrosão e que talvez uma simples pintura resolva o problema, porém, os estudos econômicos mostram que falhas por corrosão são mais do que isso.

As técnicas para proteção dos metais têm sido muito estudadas ao longo dos anos e foram encontrados diversos caminhos para isso. Um deles é o uso do cromo $\mathrm{VI}\left(\mathrm{Cr}^{+6}\right)$ como inibidor de corrosão, seja em pré-tratamentos, seja aditivando tintas. A toxicidade do cromo traz consigo um novo problema ambiental, pois esta sendo restringido por regulações ambientais e de saúde, por isso a a comunidade científica e técnica está se vendo forçada a encontrar novas alternativas que conciliem os dois principais problemas da corrosão: custo de reparo e impacto ambiental. As tintas são uma das formas de proteção contra a corrosão mais utilizada nas práticas industriais. O mercado de revestimentos na América Latina estima-se que é de 615 milhões de dólares que correspondem a 104,5 milhões de litros por ano. Desse total, ao redor de $80 \%$ é usado para revestimentos para a proteção contra a corrosão e manutenção. Além disso, os revestimentos com tintas convencionais atuam apenas como barreiras físicas que impedem a interação das espécies corrosivas com o metal. A indústria está exigindo cada vez mais revestimentos mais sofisticados e multifuncionais que aprimorem 0 desempenho e a durabilidade dos mesmos. Enquanto várias estrategias de autorreparação geráis têm sido abordadas, uma das investigações mais bem sucedidas e versátil utiliza microcápsulas que estão preenchidas com agentes de autorreparação. O futuro desses revestimentos está então atrelado à micro/nanotecnologia capaz de 
trazer o conceito de revestimentos inteligentes, ou seja, que irão ter a habilidade de se autorreparar.

Neste trabalho, foi estudada a técnica de autorreparação do revestimento de resina epóxi aditivado com microcápsulas de uréia-formaldeído contendo óleo de linhaça como agente reparador. Para comprovar que o óleo de linhaça realmente funciona como agente de autorreparação, utilizou-se a técnica de espectroscopia de impedância eletroquímica, que ajuda na avaliação quantitativa da resistência contra a corrosão da camada de tinta com e sem microcápsulas e o teste acelerado de corrosão na câmara de névoa salina para avaliação qualitativa e comparativa. Foi avaliada da mesma forma a quantidade de microcápsulas aditivadas no filme de resina epóxi e seu efeito na formação do filme protetor à base de óleo de linhaça. Os resultados mostraram que o uso de $10 \%$ em massa úmida de microcápsulas resultou em efeito autorreparador mais efetivo, comprovado por todas as técnicas empregadas para avaliação de tal efeito. 


\section{REVISÃO DA LITERATURA}

\subsection{IMPORTÂNCIA DO ESTUDO DE CORROSÃO DE METAIS}

A corrosão dos metais é percebida por alguns como um problema estético, por exemplo, os arcos de uma ponte ou o varal de roupas de casa, mas o problema vai muito além. A corrosão traz consequências às vezes irreversíveis como a diminuição das reservas naturais e danos ao meio ambiente, ou também custos por paradas não programadas, riscos pessoais e patrimoniais. O custo do fenômeno de corrosão corresponde a uma parcela significativa do produto interno bruto (PIB) dos países (algo em torno de $3-4 \%$ ) e ocorre em uma ampla gama de exemplos, que vão desde a corrosão de uma estrutura metálica exposta em um ambiente agressivo, até os implantes metálicos colocados no corpo humano. Os custos da corrosão podem ser vistos por dois pontos de vista; os custos diretos (uso de material adicional para sobreespessura, reposição de partes corroídas) e os custos indiretos, que são os previsíveis, porém dificilmente mensuráveis e de maior valor. Os estudos econômicos da corrosão (NACE International) mostram que, por exemplo, nos Estados Unidos, entre 1999 e 2001, houve um total anual de custos com corrosão de aproximadamente 276 bilhões de dólares, algo como 3,1\% do PIB desse mesmo país. Na América Latina, os países como Brasil, com os maiores índices de crescimento econômico nos últimos anos, não escapam do impacto da corrosão. No Brasil, com quase 500 bilhões de dólares de produto interno bruto, o custo anual da corrosão está ao redor de $3 \%$ do valor do PIB, ou seja, uns 15 bilhões de dólares. O custo direto anual dos meios de combate contra corrosão é de $1.38 \%$ do PIB, ou seja, 6.9 bilhões de dólares (dados obtidos da ABRACO) . Uma das principais causas da corrosão é a instabilidade dos metais em sua 
forma metálica, já que eles tendem a voltar para seus estados combinados e mais estáveis por diferentes mecanismos de corrosão. O processo de corrosão começa na superfície do metal que se encontra exposta ao meio agressivo e acaba levando à sua deterioração total se medidas preventivas não forem aplicadas.

\subsection{MÉTODOS DE PROTEÇÃO DE METAIS CONTRA CORROSÃO}

Os métodos de proteção de metais contra corrosão estão baseados na modificação de alguns ou todos os componentes do sistema na interfase metal/meio. Dentre os métodos de proteção se encontram os revestimentos de conversão, os revestimentos metálicos e os revestimentos orgânicos.

A proteção dos metais envolvendo um revestimento de conversão implica numa passivação forçada. Por exemplo, a fosfatação leva à formação de fosfatos insolúveis. A anodização é um processo de passivação eletrolítica que aumenta a espessura da camada de óxido natural dos metais para aumentar a resistência à corrosão e também oferece melhor aderência de revestimentos primários chamados de "primers" ou tintas aplicadas sobre o metal nu. Por último se encontra a cromatização, que funciona pela imersão do metal em solução de íons $\mathrm{Cr}^{+6}$.

Os revestimentos metálicos são, de certa forma, porosos e contêm defeitos e devem ser tratados com atenção principalmente quanto a sua qualidade. Dentre estes tipos de revestimentos encontram-se os revestimentos metálicos nobres, que são feitos a partir de metais que tem comportamento mais nobre do que o metal do substrato que será protegido. Por exemplo, para proteger o aço, são utilizados como metais nobres o $\mathrm{Ni}$, $\mathrm{Ag}, \mathrm{Cu}, \mathrm{Pb}$ ou $\mathrm{Cr}$. Sabendo que estes materiais podem apresentar defeitos, poros ou trincas, o que é feito nas indústrias para maximizar sua proteção é aplicar algum tipo de laca orgânica que preencha os poros, ou também, difundir um segundo metal com ponto de fusão menor que o primeiro [Gómez de León, 2004]. Seguindo a linha dos 
revestimentos metálicos, encontram-se os revestimentos de sacrifício, neste caso, o metal usado como revestimento é mais ativo, ou menos nobre que o metal do substrato e nele, os poros ou defeitos produzem efeito bem menos nocivo que no caso anterior. Os defeitos acabam se tornando em pilhas galvânicas, fazendo com que o metal base em contato com o eletrólito esteja protegido catodicamente enquanto o outro metal de revestimento que é mais ativo, sofre a corrosão. Um exemplo de revestimento de sacrifício usado sobre o aço é o zinco [Gómez de León, 2004].

Outro tipo de revestimento para a proteção de metais contra a corrosão são os revestimentos orgânicos ou poliméricos, os quais estão tendo uma maior atenção por serem de fácil aplicação e trazerem grandes benefícios protetivos para os metais. As pinturas, por exemplo, são revestimentos que além de dar aos metais um acabamento de cor, brilho e textura, oferecem propriedades de resistência aos ataques do meio ambiente onde estão inseridos. Estas propriedades são obtidas de acordo com o sistema de pintura. Normalmente um sistema de pintura compreende um "primer" ou primeira camada em contato direito com a superfície do metal, logo em seguida vem a camada intermediária e finalmente a camada de acabamento. O conjunto destas camadas (sistema de pintura) é que dita as propriedades de proteção do metal e é justamente, por meio de variações das propriedades das camadas (aditivação de substâncias) que se podem obter características diferentes para cada aplicação [Stoye e Freitag, 1998].

Existem também outras técnicas para prevenir a corrosão dos metais. Na indústria em geral, o aço é produzido em muitos casos como um metal nu o que leva a uma corrosão prematura pela manipulação do mesmo antes do uso para o qual foi destinado. Estes aços devem ter uma proteção temporária contra a corrosão atmosférica que possuem normalmente inibidores, antioxidantes e óleos. Ghanbarzadeh e Akbarinezhad (2006) estudaram a proteção conferida pelo óleo mineral de petróleo, melhorado com a adição de grupos sulfonados para a proteção do aço em comparação com óleo de petróleo convencional, e encontraram que em relação a esse último, o óleo com grupos 
sulfonados melhora as propriedades de proteção contra a corrosão entre 10 e 30 vezes mais.

\subsubsection{Revestimentos Orgânicos}

Os revestimentos orgânicos têm dupla missão, a primeira, de estabelecer uma barreira entre o material que irá ser protegido e o agente agressivo, mas também criar um aumento da resistência elétrica na interface metal/meio que servirá para a proteção do metal devido ao fato da corrosão ser um fenômeno eletroquímico.

As propriedades dos revestimentos são determinadas pelo tipo de aditivos usados na formulação. Por exemplo, há revestimentos com propriedades óticas, térmicas, mecânicas, eletromagnéticas e de higiene entre outras propriedades, e se podem obter revestimentos com propriedade de autolimpeza, antipichação, anticorrosivos [Gosh, 2006] e dentre os anticorrosivos se podem citar os revestimentos de autorreparação que atuam liberando substâncias, sob um estímulo externo, que atuam como inibidores de corrosão ou formando filmes protetores. Porém, outros fatores como tipo de substrato, forma de aplicação e condições para a formação de filme possuem um papel importante nessas propriedades finais do revestimento.

O grupo de revestimentos orgânicos compreende as tintas clássicas, os filmes híbridos, os revestimentos a base de silanos, os revestimentos contendo inibidores de corrosão, entre muitos outros. Dentre os revestimentos poliméricos anticorrosivos mais usados na indústria, se encontram aqueles a base de resinas epóxi.

Kolek (1997), caracterizou a penetração da água em revestimentos orgânicos, mais precisamente em uma laca de epóxi. Neste trabalho o autor relacionou a lei de difusão de Fick com as variações nas medidas de capacitância do revestimento com o tempo de imersão, obtendo como resultado coeficientes de difusão para a penetração da água nas camadas da laca. 
Em geral, a composição básica de uma tinta possui resina, que é a parte não volátil da tinta, é a base principal do sistema e estas levam o nome de acordo com o tipo de resina empregada, assim, por exemplo, tinta acrílica, tinta epóxi, etc [Fazenda, 1993]. Outros componentes básicos são o solvente e os aditivos. Dentre as tintas mais utilizadas nas indústrias, encontram-se as que são feitas a partir de resinas epóxi, resinas alquídicas, resinas poliuretânicas e fenólicas.

Selvaraj et al., 2009, estudaram a proteção conferida por diferentes revestimentos poliméricos, dentre os quais os mais eficientes foram as resinas a base epóxi (epóxisilicone-poliamida) para a proteção das barras de aço dentro de estruturas de concreto, que são utilizadas nas construções particularmente localizadas nos ambientes mais agressivos como são aqueles localizados próximo ao mar.

\subsubsection{Pré-tratamentos}

Os pré-tratamentos aplicados aos substratos são fundamentais em alguns casos para a proteção contra corrosão já que ajudam na aderência de "primers" ou primeiras camadas de tinta, pois nem sempre se tem um revestimento orgânico com boa aderência, o que leva à sua delaminação da superfície do metal.

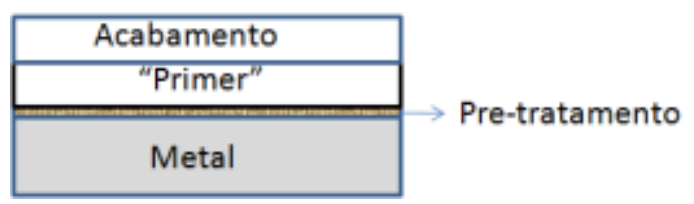

Figura 1 - Sistema pintura para a proteção de metais com uso de pré-tratamento.

É bem sabido na indústria que íons metálicos como o cromo (VI) oferece uma ótima proteção contra a corrosão, porém, tem havido necessidade de substituir esses pré- 
tratamentos tradicionais por se tratar de substâncias tóxicas e ambientalmente perigosas. Kendig e Buchheit, 2003 trabalharam com pré-tratamentos ricos em magnésio $(\mathrm{Mg})$ para a proteção dos metais usados na indústria aeronáutica (ligas de alumínio) com o objetivo de substituir os pré-tratamentos com cromo (VI) e concluíram que são iguais ou até melhores as propriedades de proteção contra à corrosão quando se trabalha com pré-tratamentos ricos em Mg.

Silveira (2010), defendeu uma tese sobre as propriedades anticorrosivas de camadas de conversão de taninos extraídos da casca de acácia negra e do pinheiro usando-os como prétratamentos para a proteção do aço carbono dos impactos ambientais. Se conclui neste estudo que, quando os taninos são usados como inibidores a sua eficiência dependera da concentração do tanino porém,, quando são usados em amostras previamente fosfatizadas tem uma contribuição maior na resistência a corrosão.

\subsubsection{Revestimentos "inteligentes" de autorreparação}

Os revestimentos "inteligentes" ou smart coatings são aqueles sistemas de proteção estruturados para dar uma resposta de melhora diante de um estímulo externo. Eles reagem às condições externas tais como temperatura, tensão ou contaminante do ambiente de forma seletiva. As pinturas são sistemas de revestimento que podem adquirir características "inteligentes" quando modificado um dos seus constituintes. Um sistema de pintura basicamente esta conformado por três camadas principais. A primeira chama-se de "primer" que é a camada que está em contato direto com o pré;tratamento ou não. Logo em seguida vem a camada intermediária e finalmente a camada externa ou "top coat" que é a camada que confere o acabamento final. De todas as partes mencionadas a mais importante é o "primer", pois é ali que se pode promover além da forte adesão ao substrato também adquirir propriedades de autorreparação para a proteção contra corrosão do metal. Também é com o primer que 
se pode garantir uma boa adesão das camadas subsequentes garantindo uma proteção mais eficiente. Tradicionalmente as tintas anticorrosivas possuem pigmentos inibidores de corrosão no primer. Novos estudos mostram que no primer podem ser armazenadas partículas contendo compostos formadores de filme ou agentes de cura (Kumar, Stephenson et al., 2006; Zheludkevich, Shchukin et al., 2007). Outros estudos sobre revestimentos "inteligentes" são apresentados ao longo deste trabalho onde são discutidas as diferentes ações e mecanismos de autorreparação, o que faz com que sejam chamados de "revestimentos inteligentes" ou de "smart coatings".

\subsection{PROTEÇÃO POR EFEITO DE AUTORREPARAÇÃO OU "SELF-HEALING"}

Históricamente, os requisitos rigorosos de controle de corrosão foram desenvolvidos baseado no desempenho do cromo que oferece uma excelente proteção contra a corrosão de ligas ferrosas e não ferrosas. Ha estudos que mostram uma formação de uma camada de cromo tri/hexavalente que interage com o óxido do metal, o que os autores atribuem como autorreparação, pois o cromato pode ser liberado a partir do revestimento e migrar para uma região danificada. Aqui pode ocorrer a redução eletroquimica para $\mathrm{Cr}^{+3}$ protegendo a superfície contra a corrosão (Frankel e McCreery, 2001). Com as novas restrições que impedem o uso de cromo, novas formas de autoreparação surgiram, até inspiradas na nossa própria natureza.

O corpo humano consegue fazer coisas incríveis para a sua autorreparação quando ocorre alguma contusão. Tal analogia pode ser associada à tecnologia dos materiais inteligentes ou de autorreparação. Assim como o corpo diante de uma agressão reage liberando uma substância de autorreparação que liga novamente os tecidos danificados, os materiais de autorreparação conhecidos também como 'self-healing' são aqueles que têm a capacidade de responder diante de estímulos físicos, químicos e mecânicos, corrigindo a estrutura danificada para proteger o substrato que esta sendo exposto ao meio corrosivo. Revestimentos com efeito de self-healing possuem pequenas cápsulas (micro/nano) que no seu interior contêm 0 agente de autorreparação e que só é liberado quando são quebradas as cápsulas seja por algum 
dano físico ou mecânico, diferença de temperatura, $\mathrm{pH}$ e até por efeito dos raios de UV. São várias as aplicações do uso das micro/nano cápsulas; desde os anos 50 foram produzidas microcápsulas de corantes para a manufatura de papel de cópia livre de carbono (papel químico) [Yu, Wang et Al., 2002]. Além disso, há também aplicações na indústria de cosméticos [Thies, 1990], têxteis [Nelson, 2002], biotecnologia biomateriais- [Sukhorukov, Fery et al., 2005; Tao, Chen et al., 2007; Bhathena, Kulamarva et al., 2008], farmacêutica [Nechaeva, Varaksin et al., 2001], alimentos [Sukhorukov, Fery et al., 2005; Forssell, Partanen et al., 2006], e também, como mencionado antes, na área de revestimentos protetores contra corrosão [Rule, Sottos et al., 2007; Zheludkevich, Shchukin et al., 2007; Dhirendra et al., 2008; Blaiszik, Caruso et al., 2009]

A figura 2 representa a ação das microcápsulas quando um risco é provocado na superfície revestida. O estímulo (dano mecânico provocado pelo risco) faz com que as microcápsulas se rompam despejando o agente de autorreparação dentro da fissura e este se polimeriza criando um filme protetor do substrato, evitando ou pelo menos retardando $o$ ataque corrosivo pelo meio.

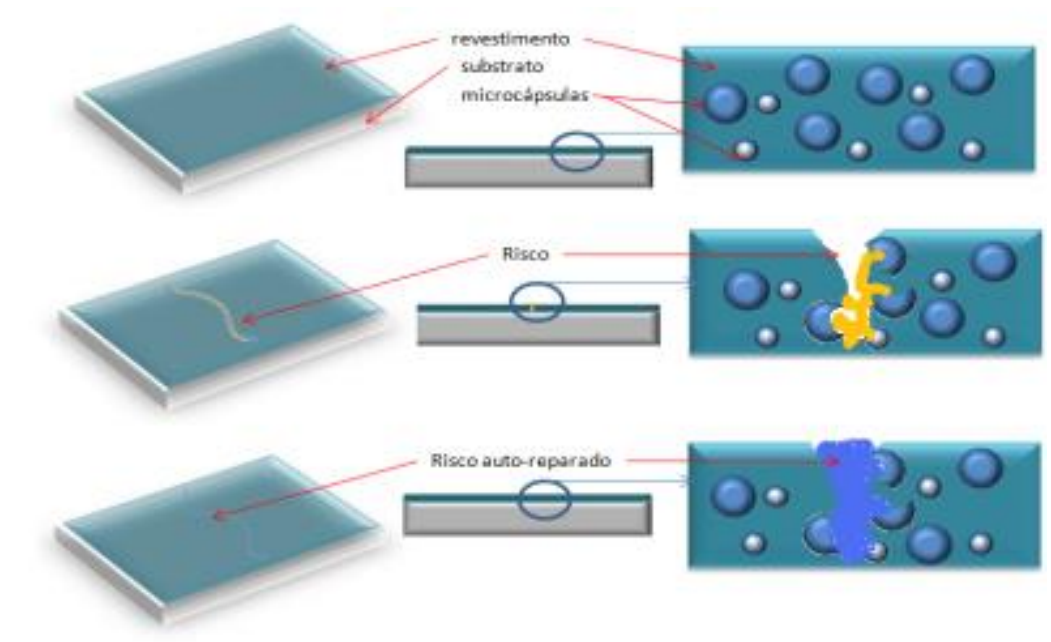

Figura 2 - Esquema do processo de autorreparação conferido por microcápsulas numa tinta aplicada sobre substrato metálico. 
Os revestimentos são camadas externas que protegem os metais dos ataques corrosivos provocados pelos meios nos quais se encontram. Como dito anteriormente, dentro da composição básica do revestimento temos os aditivos, alguns são aditivos de reologia, de cinética, de processo e de preservação (Fazenda, 1993). Nos revestimentos inteligentes, são as microcápsulas de autorreparação, que vão reagir diante de estímulos físicos, químicos e mecânicos que danificarem o revestimento e liberarão o seu conteúdo que pode ser um inibidor de corrosão ou um formador de filme. Em alguns casos é necessário ter a presença de catalisadores que ajudam a reação de polimerização do agente de autorreparação formador de filme, em outros, pela natureza do agente, esta reação é livre de catalisador. Trabalhos recentes (Dhirendra et al., 2008; Nesterova et al., 2011; Samadzadeh et al., 2011) foram realizados e encontrou-se que a escala de tamanho das cápsulas é de aproximadamente 100 micras, mas há interesse em algumas aplicações, em reduzir esse tamanho a escalas nanométricas. Estudos mostram que é possível variar o tamanho das cápsulas usando diferentes velocidades de agitação na etapa de formação da emulsão. Diferentes processos para obter os revestimentos de "selfhealing" foram realizados por vários pesquisadores envolvendo diferentes agentes de autorreparação e técnicas de avaliação do desempenho desses revestimentos frente a diferentes meios corrosivos.

\subsubsection{Mecanismos de autorreparação}

Para que ocorra a autorreparação do revestimento este deve ter o material ativo e autorreparador liberado de uma maneira rápida e eficiente a partir das cápsulas e de tal forma que devolva a integridade do revestimento e continue atuando como protetor do substrato contra a corrosão. Um sistema de autorreparação pode ter o agente ativo na camada de pré-tratamento, no "primer ou clear" ou no "top coat". Em geral, existem diferentes métodos de conter o agente de autorreparação dentro de diferentes tipos de reservatórios. A formação desses reservatórios requer algumas propriedades quanto à 
estrutura da parede para dar assim a característica "smart" ou "inteligente", tratada anteriormente. As microcápsulas são o tipo de reservatório que será tratado neste trabalho.

Shchukin e Sukhorukov(Sukhorukov, Fery et al., 2005; Shchukin, Zheludkevich et al., 2006) apresentam os diferentes tipos de reservatórios entre eles os feitos pelo processo LbL (layer-by-layer) por suas siglas em inglês significa camada por camada. Sua abordagem envolve a autorreparação de revestimento com nanorreservatórios feitos pelo processo de camada por camada molecular com pequenos recipientes montados sobre partículas inertes como sílica ou argilominerais, e alternando camadas de polieletrólitos carregados positiva e negativamente e, entre elas, camadas de um inibidor de corrosão.. As nano partículas foram, então, aditivadas em um gel de sílica solúvel contendo óxido de zircônio para cobrir a parte metálica que neste caso foi uma liga de alumínio. Esses reservatórios podem ser feitos também a partir dos chamados nanotubos de carbono ou argilominerais como a haloisita e outros.

Oliver et al (2010), na busca de melhorar a proteção contra a corrosão do aço carbono, usaram uma resina epóxi como revestimento, mas esta continha argila natural organicamente modificada com substâncias como ácido aminotrimetilfosfônico ou também IBA (ácido indole-3 butírico) para serem compatíveis e serem armazenados nesta argila. Em um estudo prévio já tinham demonstrado que efetivamente melhorava a proteção do aço carbono, mas o seguinte passo foi descobrir se diante de um defeito executado qual seria o comportamento deste revestimento, e encontraram que quando o processo de corrosão começa na área do defeito, o pH geralmente diminui o que incita a atuação da argila a liberar a substância (inibidor) sendo este chamado pelos autores, um comportamento de autorreparação.

Samadzadeh, et al (2011) e Dhirendra et al (2008) também na busca de proteger os substratos utilizaram outro mecanismo para a autorreparação do filme que revestia o metal (aço carbono e latão) em estudo. Aditivando uma resina epóxi com cápsulas contendo óleos secantes (óleo de tung -árvore chinesa- e óleo de linhaça, 
respectivamente), posteriormente aplicando-se a resina sobre os substratos e após a cura, um defeito foi executado para que as microcápsulas quebrassem e liberassem o óleo formador de película autorreparadora. A vantagem de usar este tipo de óleo, é que estes se polimerizam ao interagir com o oxigênio do ar, reparando o dano sofrido no revestimento e criando uma barreira contra o meio corrosivo.

\subsubsection{Processo para a microencapsulação}

A microencapsulação tem como objetivo poder guardar líquidos dentro de reservatórios onde esses líquidos vão atingir um objetivo específico como alguns dos casos mencionados previamente. $\mathrm{Na}$ indústria de alimentos, tem-se como objetivo microencapsular líquidos que prolonguem os sabores dos alimentos por mais tempo, da mesma forma que a indústria de revestimentos se interessa em ter cápsulas capazes de armazenar agentes de autorreparação e catalisadores, isolados um do outro, e poder controlar sua ação. Com as microcápsulas pode-se ter uma liberação controlada desses líquidos (autorreparadores e catalisadores) os quais serão liberados quando a cápsula que os contém seja quebrada por ação mecânica ou fisico-química. Além disso, as microcápsulas têm a função de manter isolado o liquido de interesse até que seja necessária sua atuação. Dentre os estímulos externos recordamos as mudanças no $\mathrm{pH}$, temperatura, esforços mecânicos ou contaminantes do ambiente.

Autores como Dubey et al., (2009) descrevem o processo de microencapsulação por duas maneiras. A primeira trata do processo onde reações químicas acontecem entre os componentes da emulsão para a formação da microesfera, e o segundo onde apenas fenômenos físicos são os responsáveis pela formação das microcápsulas, sem haver reação química. $\mathrm{Na}$ tabela 1 se apresentam alguns exemplos das duas formas para o processo de microencapsulação. 
Tabela 1-Métodos para realizar a microencapsulação

\begin{tabular}{|l|l|}
\hline Métodos Quimicos & Métodos fisico-mecânicos \\
\hline Polimerização em suspensão & Evaporação de solvente-extração \\
\hline Polimerização em emulsão & Coacervação \\
\hline Dispersão & Spray drying \\
\hline Interfacial & Co-extrusão \\
\hline
\end{tabular}

Brown et al., 2003, conseguiram a formação de microcápsulas a partir do método químico de polimerização de uréia-formaldeído para formar as paredes das cápsulas. Inspirados em essa metodologia foi usado com sucesso por muitos outros autores tendo algumas variações para obter microcápsulas com diversas características, uma das quais é o tamanho da microcápsula para seu propósito final.

A classificação das microcápsulas é dada pelo seu tamanho e morfologia. A partir de um mícron $(1 \mu)$ até $1000 \mu$, são chamadas de microcápsulas, mas há também algumas cápsulas cujo diâmetro está na escala nanométrica, são chamadas de nanocápsulas para enfatizar que são muito menores, argumentam Scott R. White et al, 2007. A variação do tamanho das microcápsulas é dado principalmente pela velocidade utilizada na agitação da mistura de substâncias que formam a emulsão e que contem o composto que precisa ser microencapsulado. Quanto maior a velocidade de agitação, menor será o tamanho das micelas que funcionam como "formas" das futuras cápsulas. Numa emulsão de óleo em água há pequenas partículas de óleo que se encontram dispersas num líquido não miscível com ele como se mostra na imagem da figura 3 (a). Isso ocorre pela formação das micelas as quais formam uma cápsula cujo centro é apolar (contem a fase óleo) e suas paredes são polares como se mostra na figura 3 (b). 


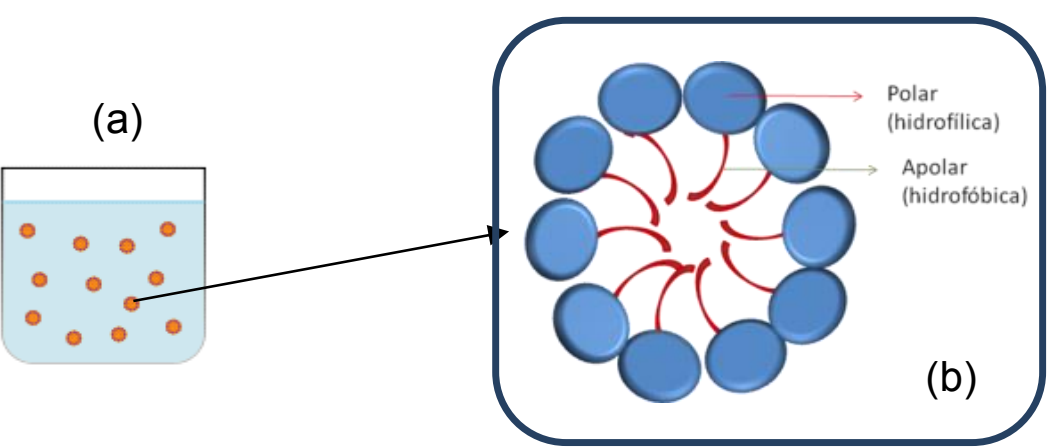

Figura 3 - Micela precursora para a formação das microcápsulas .

Considerando os métodos físicos, o instituto de pesquisa de Southwest dos Estados Unidos da América encontrou uma forma de microencapsulação por meio da coextrusão como está representado na figura 4. Tanto o líquido a ser encapsulado como o que formará a parede são bombeados através de tubos concêntricos os quais próximos à saída diminuem o diâmetro e, com a incidência de vibração, conseguem-se formar microgotículas que são as microcápsulas (Ghosh, 2006).

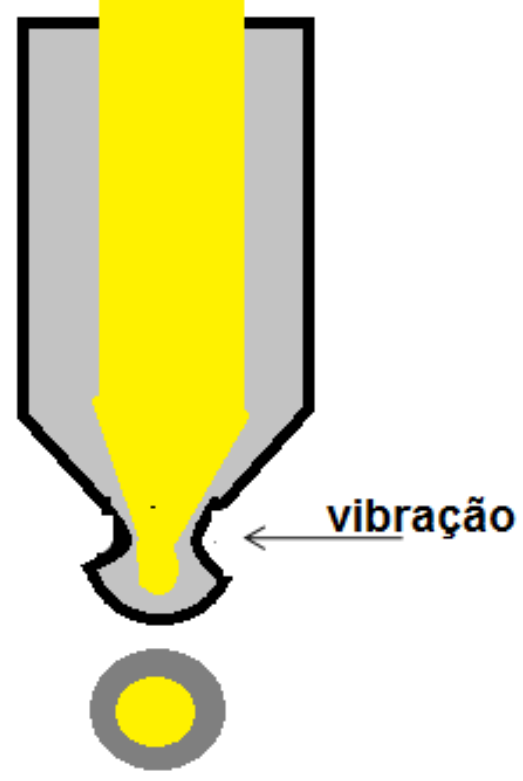

Figura 4- llustração da formação de microcápsulas pelo método de co-extrusão. 


\subsection{TÉCNICAS DE VALIDAÇÃO DO PROCESSO DE MICROENCAPSULAÇÃO}

Quando se prepara uma emulsão para a formação de micro ou nanocápsulas são necessárias técnicas para validar que o processo realmente atingiu êxito e também caracterizar as propriedades desejadas para as cápsulas. Uma das características importantes é a formação de uma parede sólida e estável das cápsulas pois é essa parede que vai conter o material de interesse, neste caso, o agente de autorreparação. Outra característica fundamental é ver a morfologia das cápsulas, ou seja, se a parede delas é grossa, robusta, pois isso pode causar variações como as de aderência e compatibilidade com os demais compostos do sistema de pintura. Esta morfologia mais detalhada pode ser obtida pela microscopia eletrônica de varredura (MEV).

A microscopia eletrônica de varredura (MEV) é uma técnica usada por pesquisadores para obter imagens de superfícies para sua caracterização. Nos estudos dos materiais self-healing, as imagens obtidas por MEV ajudam na caracterização dos micro ou nanoreservatórios que atuarão na autorreparação dos revestimentos para a proteção das superfícies metálicas recobertas. A caracterização morfológica das microcápsulas é possível graças às imagens obtidas por MEV (Cosco et al., 2007; Zheludkevich et al., 2010; Nesterova et al., 2011). Por meio dessas imagens podemos descobrir a efetividade das etapas prévias da microencapsulação. Por exemplo, de acordo com o tamanho das microcápsulas e a aparência das paredes, é possível correlacionar parâmetros como velocidade de agitação da emulsão para formação de cápsulas ou inclusive as características do material encapsulante (que constitui as paredes) como foi avaliado por Rule et al., (2007).

Com as imagens obtidas por esta técnica, também é possível saber o tamanho das partículas. Normalmente se toma como primeira referência de sucesso da microencapsulação, as imagens obtidas ao microscópio ótico (Nesterova et al., 2011). Ting et al. (2010) na determinação de um processo otimizado para a obtenção de 
microcápsulas de poli(uréia-formaldeído) conseguiram identificar que as cápsulas possuem uma parede estável e não são gotículas do material disperso na fase continua como ocorre em uma emulsão convencional. Finalmente, com esta técnica é possível fazer também um acompanhamento da distribuição de tamanho de partículas formadas de acordo com a velocidade de agitação empregada durante o processo de emulsão.

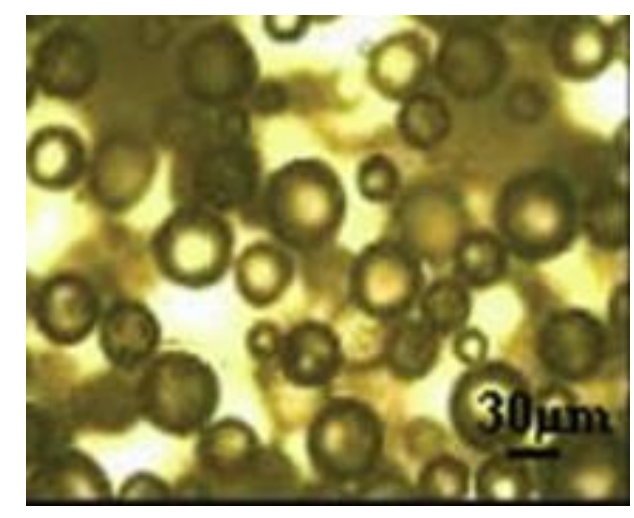

(a)

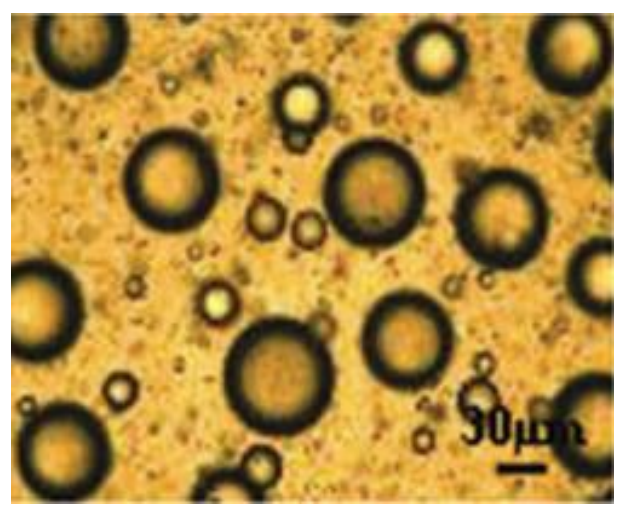

(b)

Figura 5 - Imagens das microcápsulas vistas ao microscópio ótico (Ting et al., 2010)

Após provar que houve formação de microcápsulas, o estudo da morfologia é feito por MEV como fizeram alguns pesquisadores (Dhirendra et al., 2008; Samadzadeh et al., 2011)

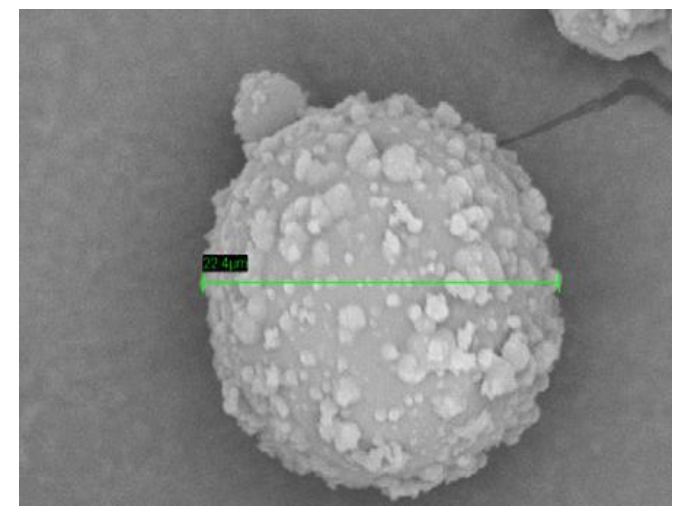

(a)

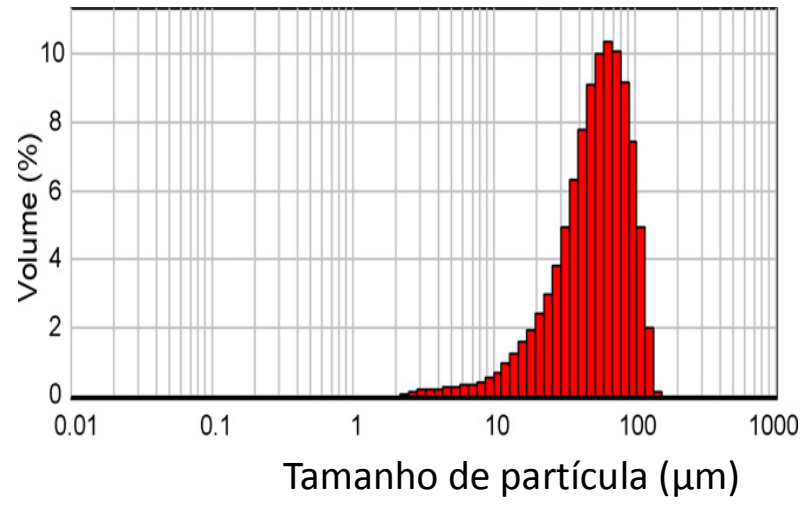

(b)

Figura 6 - Imagem obtida por MEV de uma microcápsula de uréia-formaldeído contendo óleo de linhaça (a) e gráfico de distribuição de tamanhos de partículas (b) - (Dhirendra et al., 2008) 


\subsection{TÉCNICAS PARA AVALIAR O EFEITO DE AUTORREPARAÇÃO OU DE "SELF-HEAIING"}

Quando se tem um revestimento com efeito de autorreparação ou "self-healing" e se quer saber se realmente o substrato está sendo protegido, não basta apenas olhar a peça revestida e não visualizar nenhum produto de corrosão, mas sim é necessário recorrer às técnicas de avaliação que apresentem valores que indiquem de uma forma quantitativa, quanto o filme de autorreparação está sendo efetivo, e como é que ele varia de acordo com as condições sob as quais se encontra. As técnicas utilizadas na avaliação do efeito "self-healing" são a varredura com eletrodo vibratório (SVET), a espectroscopia de impedância eletroquímica clássica (EIE) e a localizada (LEIS), sendo a EIE a mais utilizada e na qual este trabalho de pesquisa se apóia.

A técnica de SVET (scanning vibrating electrode technique) é uma técnica que permite fazer o mapeamento do campo elétrico que é gerado na superfície de um corpo de prova ao se encontrar eletroquimicamente ativo. Com esta técnica se detectam as mudanças locais da densidade de corrente presente na superfície devido ao fluxo de íons gerado entre os sítios anódicos e catódicos o que faz dessa técnica uma das mais efetivas para detectar o fenômeno de corrosão em substratos nus, bem como nos revestidos. Esta técnica também permite com o uso de microeletrodos - sensores mapear a variação do $\mathrm{pH}$, por exemplo, onde valores muito baixos de $\mathrm{pH}$ mostram a dissolução do metal em sítios de atividade anódica. Zheludkevich et.al (2007) usaram a técnica de SVET para investigação do processo de autorreparação de filme dopado com reservatórios contendo um inibidor de corrosão orgânico (benzotriazol). A variação das correntes é apresentada como a variação de cores no mapa de correntes. Taryba et al. (2011), trabalharam com a técnica de SVET para analisar o efeito de autorreparação dos revestimentos "inteligentes" aplicados sobre o aço galvanizado quando há um defeito e o corpo de prova é imerso em solução de $\mathrm{NaCl} 0.005 \mathrm{M}$. Assim, os autores observaram as zonas de atividade catódica e anódica e, comparando cada imagem, foi possível ver o efeito de nanorreservatórios contendo inibidor de corrosão, 
após a execução do defeito, a substância que foi liberada ajudou à diminuição do fluxo de corrente anódica, que representa atividade corrosiva.

Como dito anteriormente, a técnica mais utilizada na avaliação do efeito autorreparador é a espectroscopia de impedância eletroquímica, EIE, também conhecida por EIS (Electrochemical Impedance Spectroscopy), é usada por vários pesquisadores para caracterizar e avaliar revestimentos orgânicos que protegem superfícies metálicas dos ataques corrosivos. Com esta técnica, permite-se estudar e ter medidas de velocidade de corrosão em meios de alta e baixa condutividade (Montemor e Ferreira, 2007).

\subsubsection{Técnica de espectroscopia de impedância eletroquímica}

A espectroscopia de impedância eletroquímica sempre esteve focada no que ocorre no metal, ou em como este corrói. Mas com a chegada dos revestimentos como alternativa de proteção dos metais, a técnica tornou-se mais útil, pois entregava dados quantitativos da degradação do revestimento antes que os danos fossem visíveis. Esses dados são representados em dois tipos diferentes de diagramas chamados Nyquist e Bode. No diagrama de Nyquist, a impedância "Z" está composta de uma parte real no eixo ' $x$ ' e uma parte imaginária na ordenada. Cada ponto deste diagrama representa um vetor da impedância para um dado valor de frequência $(\omega)$, com o valor do módulo de impedância $|Z|$ e um ângulo de fase $\varphi$ associado. No diagrama de Bode, se grafica o log da frequência $(\omega)$ no eixo ' $x$ ' e o módulo $|Z|$ e ângulo de fase na ordenada. O diagrama de Bode permite obter informação mais complexa que não é tão visível no diagrama de Nyquist, como por exemplo, quando no eletrodo se tem mais de uma reação ou processo, além disso, a partir deste diagrama, também é possível determinar os valores da resistência do eletrólito. Com tudo isto, é possivel estudar a evolução de um revestimento, pois se consegue determinar a resistência do filme ou dos seus poros por meio dos valores de log IZI (Wolynec, 2003). Varios pesquisadores 
utilizaram principalmente o diagrama de Bode de módulo da impedância versus a frequência para a interpretação da autorreparação dos revestimentos.

Os dados obtidos pela EIE evidenciaram os diferentes fenômenos eletroquímicos que ocorrem, no caso de um substrato revestido, a interfase entre o eletrólito e o revestimento e entre a interfase do revestimento e o metal. Nas altas frequências, se observa a resposta capacitiva do filme, e nas baixas frequências a resistência da camada de produtos de corrosão presentes na interfase metal-revestimento (Zheludkevich, Shchukin et al., 2007).

Esta técnica funciona com corrente alternada, ao contrário dos métodos tradicionais de corrente contínua, o que permite o uso de sinais com menores amplitudes que não perturbam as propriedades do eletrodo de trabalho (Wolynec, 2003). A EIE caracteriza o fenômeno da corrosão que ocorre em alguns metais que estão revestidos como também ajuda a comparar a resistência à corrosão obtida com os diferentes revestimentos (Blaiszik, Kramer et al., 2010; Zheludkevich, Poznyak et al., 2010) e determina a perda de aderência do revestimento (E.P.M van Westing et al., 1993)

No estudo realizado por Kartsonakis et al (2011), eles usaram como revestimento inteligente, uma resina epóxi contendo nanorreservatórios cerâmicos contendo MBT (2mercaptobenzotiazol) para a proteção do aço zincado. Neste estudo, a avaliação da autorreparação foi feita pela técnica de espectroscopia de impedância eletroquímica usando um sistema de três eletrodos, tendo uma área exposta de $2,0 \mathrm{~cm}^{2}$, um eletrodo de referência de calomelano saturado,SCE, e um contra-eletrodo de platina. A faixa de frequência usada foi de $100 \mathrm{kHz}$ até $5 \mathrm{mHz}$ (figura 7 ). Os corpos de prova com um defeito de $1 \mathrm{~mm}$, foram expostos a uma solução de $\mathrm{NaCl} 5 \mathrm{mM}$. Nesse estudo, os resultados apresentados nos diagramas de Bode, para as peças com o revestimento aditivado com $10 \%$ em volume de nanorreservatórios contendo MTB, mostraram três constantes de tempo, uma em altas frequências representando o filme, uma segunda na faixa de frequências intermediárias devido aos processos que ocorrem na interfase metal-revestimento, e uma terceira constante de tempo é vista na região de baixas 
frequências e é atribuída ao processo de corrosão. O que é mais importante nestes resultados é o aumento do módulo de impedância ao longo dos primeiros tempos de exposição do defeito ao eletrólito, sendo este fenômeno reconhecido pelos autores como a autorrepação do revestimento dada pela atuação dos nanorreservatórios contendo o inibidor MBT.
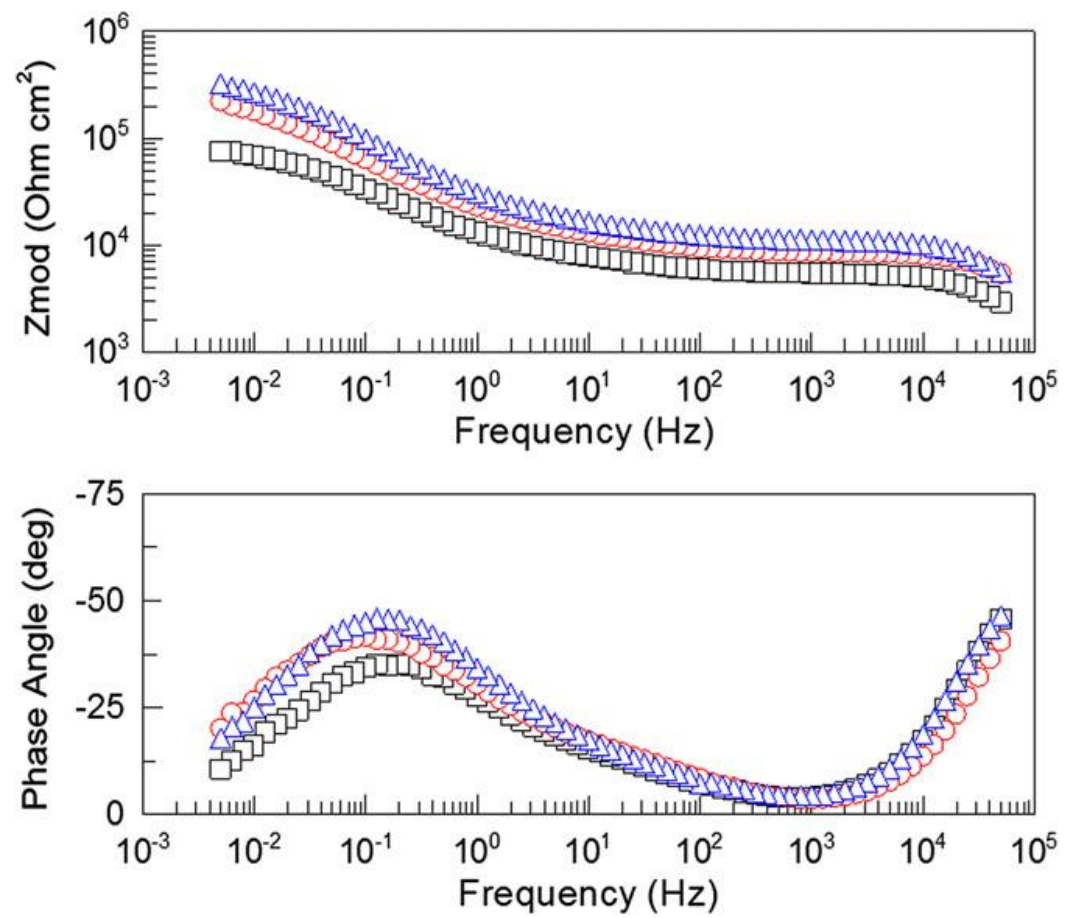

Figura 7- Diagrama de Bode para aço HDG revestido com resina aditivada com nanorreservatórios contendo 2-mercaptobenzotiazol, em solução de $\mathrm{NaCl} 5 \mathrm{mM}$ e com defeito no revestimento. preto: seis dias, vermelho: sete dias, azul: 10 dias- (Kartsonakis et al 2011)

Samadzadeh et al (2011), trabalharam com a técnica de EIE para o estudo da autorreparação conferida pelo óleo de tung contido em microcápsulas. Neste estudo, o revestimento aplicado sobre os painéis de aço carbono estava aditivado com $12 \% \mathrm{em}$ massa de microcápsulas e o defeito foi executado com estilete, permitindo-se a liberação do óleo e deixando-o 24 horas para ser polimerizado. Em uma célula de três eletrodos, sendo o eletrodo de $\mathrm{Ag} / \mathrm{AgCl}$ o de referência, uma lâmina de aço inoxidável AISI-316 como contra eletrodo e o substrato em estudo com uma área exposta de 17 $\mathrm{cm}^{2}$ como o eletrodo de trabalho, foram realizados os ensaios eletroquímicos em uma solução de $\mathrm{NaCl} 3.5 \%$, em uma faixa de frequência entre 0,010-100.000 Hz. As medidas foram realizadas tanto para os corpos de prova revestidos com resina 
aditivada como para os revestidos com resina sem aditivar. Os resultados obtidos pelos diagramas de bode mostraram que realmente há uma atuação de barreira dada pelo filme formado com óleo de tung enquanto os corpos com a resina sem aditivar apresentaram uma degradação imediata quando havia um defeito. Neste caso, os corpos de prova ficaram imersos por dias e, mesmo o revestimento sem defeito, que tinha sua resistência diminuída com o tempo, foi seguido de perto pelo o filme formado com o óleo, mostrado na figura 8.

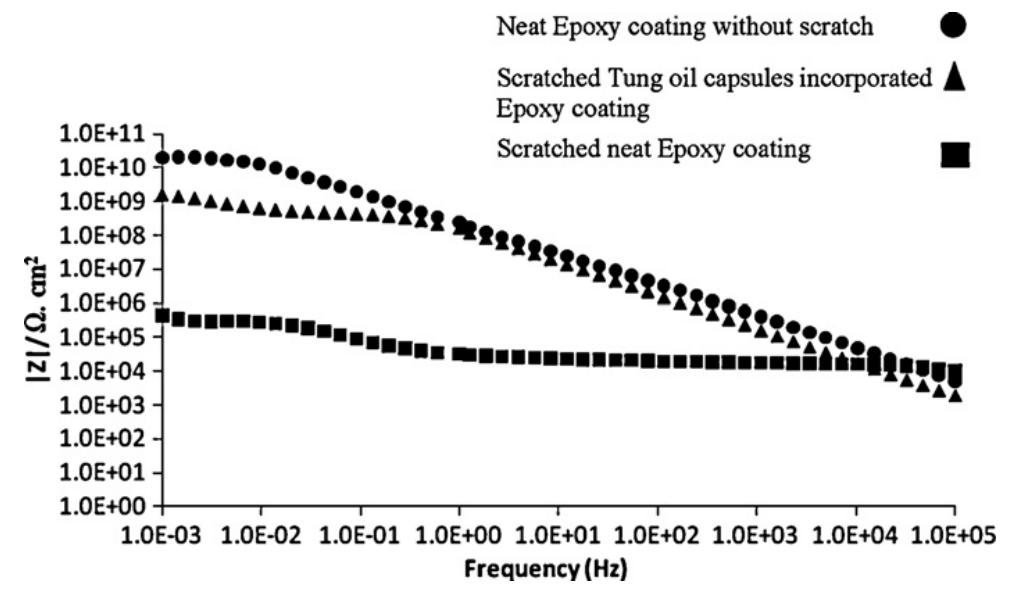

(a)

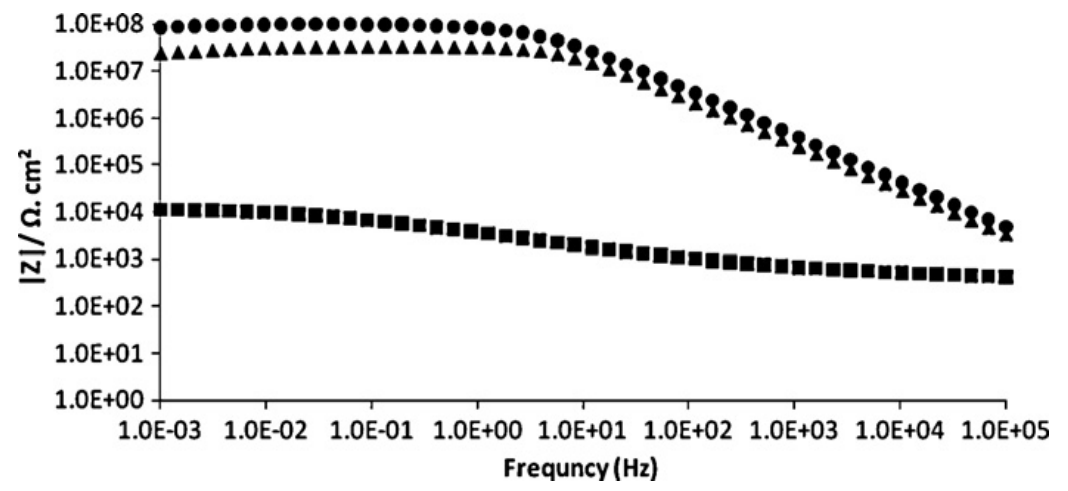

(b) 


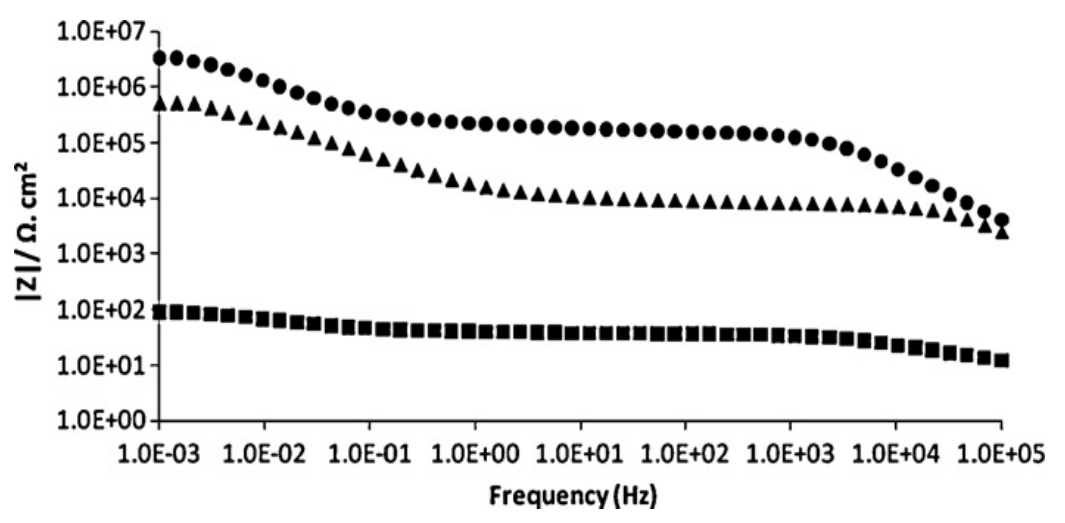

(c)

Figura 8- Diagramas de Bode do aço revestido com resina aditivada com microcápsulas contendo óleo de tung imersa durante (a) um dia, (b) sete dias, (c) 14 dias em solução aquosa de $\mathrm{NaCl} 3.5 \%$ (Samadzadeh, et al 2011

Outros metais como as ligas de alumínio e outros aços foram estudados usando revestimentos "inteligentes" ou de autorreparação e avaliados por meio de EIE (Cosco et al., 2007; He e Shi, 2009; Zheludkevich et al., 2010).

Zheludkevic et al., (2007), mostraram a avaliação por EIE das propriedades autorreparadoras dos revestimentos "inteligentes" usando espécies inibidoras dentro de nanocontainers ou nanorreservatórios. A espécie inibidora de corrosão foi o benzotriazol. O objetivo dos autores foi determinar uma relação entre o aumento da impedância em baixas frequências em função do tempo de imersão em solução de $\mathrm{NaCl}$. Os resultados obtidos pela EIE revelam que o revestimento contendo esse inibidor apresenta uma evolução com aumento do módulo de impedância atribuindo-se este aumento à ação do inibidor encapsulado nos nanorreservatórios.

Oliver et al. (2010), trabalharam tanto a técnica EIE como a LEIS para avaliar a autorreparação do revestimento de resina epóxi aditivada com argila modificada, aplicada sobre aço carbono. Usando um sistema de três eletrodos sendo o calomelano saturado o eletrodo de referência, uma lâmina de platina como contra eletrodo e o aço carbono revestido com uma área exposta de $28 \mathrm{~cm}^{2}$ como eletrodo de trabalho. Para as medidas de LEIS, usaram o sistema de 5 eletrodos usado previamente em um outro 
estudo dos mesmos autores. Para observar o efeito autorreparador, um defeito foi executado com estilete, o eletrólito empregado na EIE foi uma solução de $\mathrm{NaCl} 0,5 \mathrm{M}$ e para a LEIS uma solução de $\mathrm{NaCl} 0,001 \mathrm{M}$. Os resultados apresentados mostraram que as propriedades de barreira do revestimento de resina epóxi são significativamente maiores quando esta é aditivada com a argila modificada do que a resina epóxi sem aditivação (figura 9).

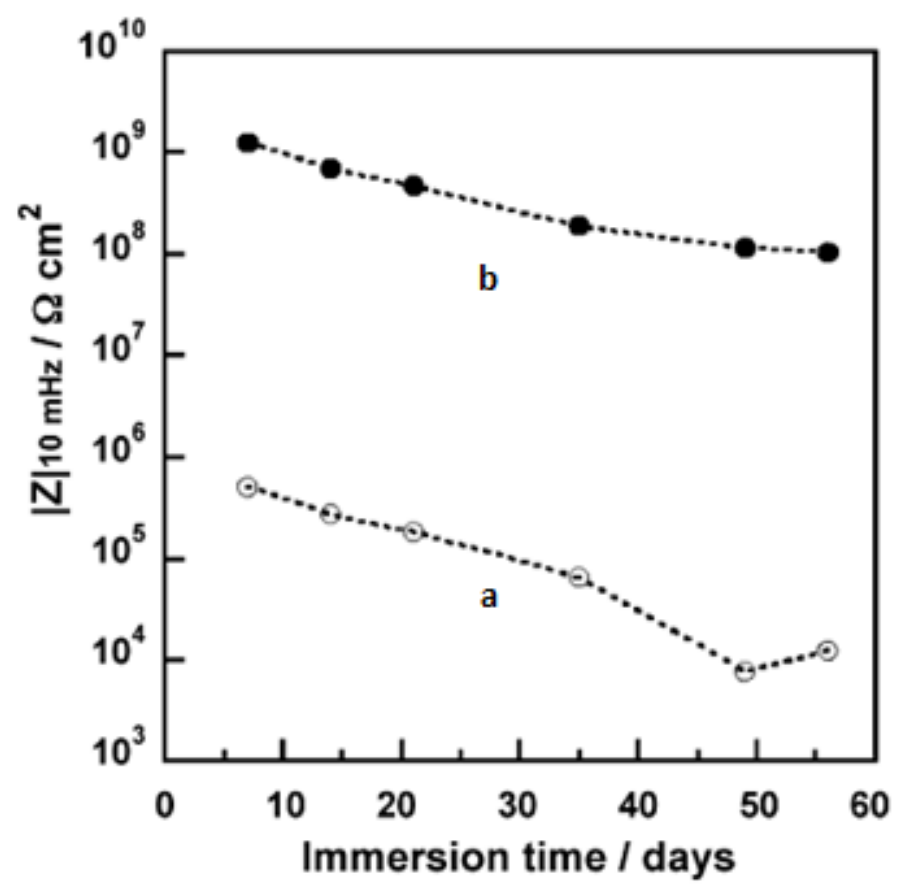

Figura 9 - Resposta comparativa da impedância para aço revestido com aditivação (esferas cheias) e sem aditivação (esferas vazias), em solução de $\mathrm{NaCl} 0,5 \mathrm{M}$, com defeito feito manualmente (a) resina epóxi pura, (b) resina contendo $2 \%$ argila modificada [Oliver et Al 2010]

Quando se possuem equipamento de alta tecnología, é possivel corroborar os resultados obtidos pela EIE com maior detalhe. Oliver et al. (2010) em concordância com os resultados de EIE, a análise feita pela técnica de LEIS (figura 10) demonstra que para a resina pura, à medida que aumenta o tempo de exposição à solução agressiva, aumenta a admitância (diminui o módulo de impedância a $10 \mathrm{mHz}$ ) na borda do defeito, associado com a perda de aderência do revestimento. Quando há o inibidor na solução, a atuação do mesmo não é tão notória quanto à diminuição significativa da admitância quando se usa a resina epóxi aditivada com argila modificada contendo inibidor. 


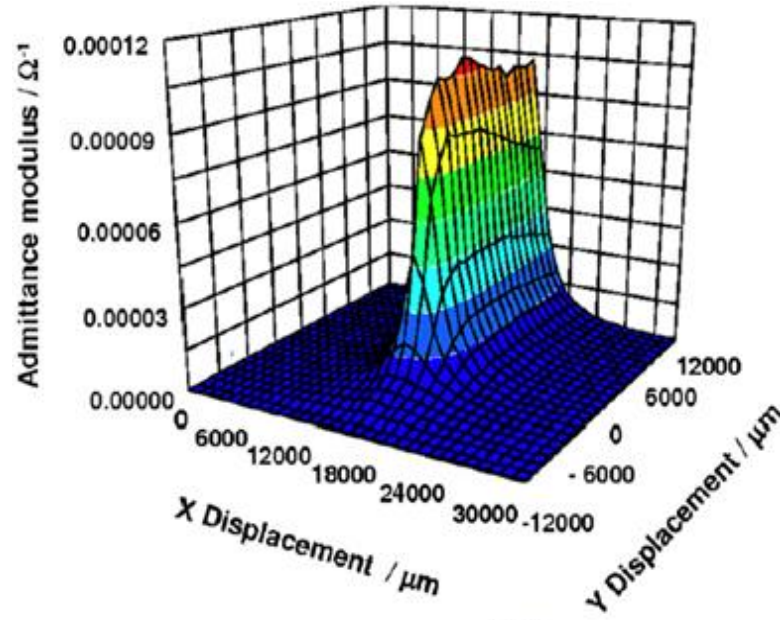

(a)

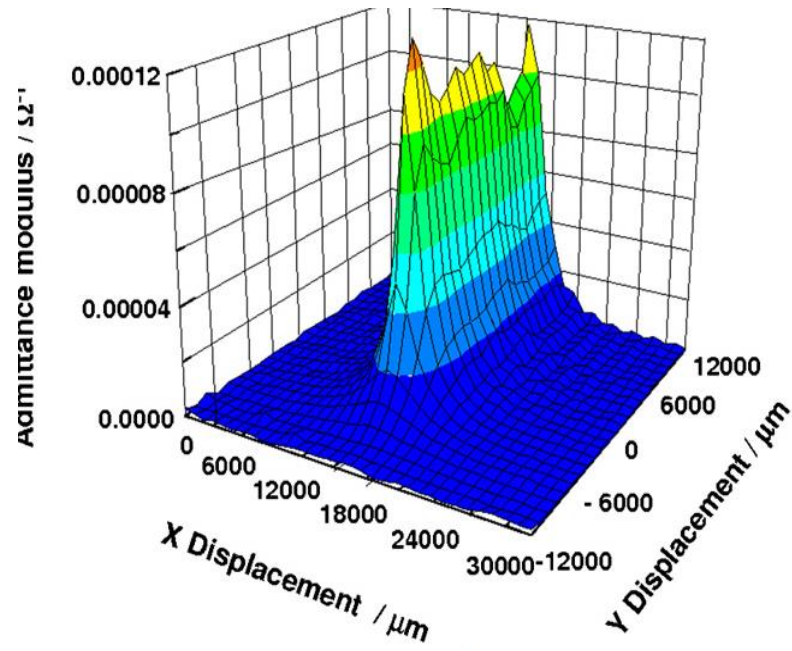

(C)

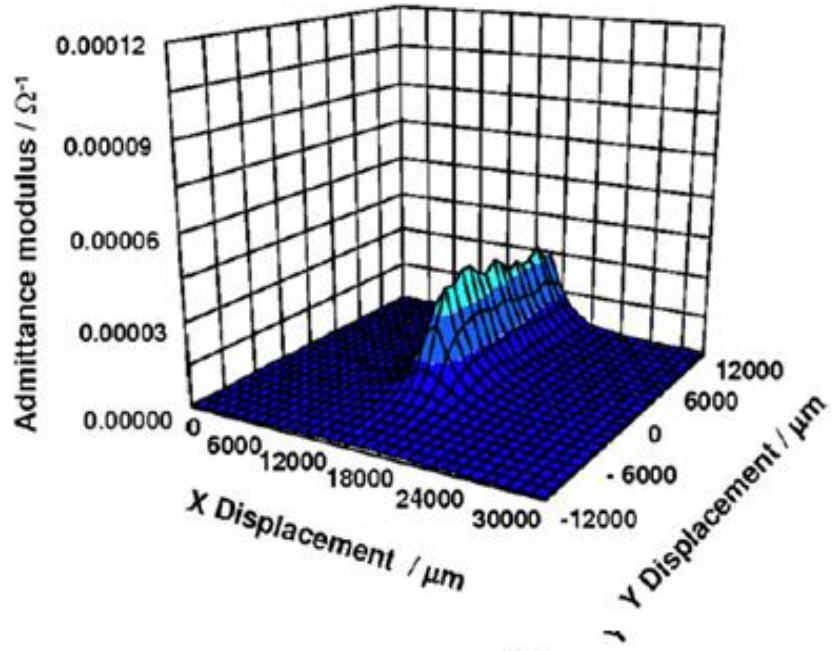

(b)

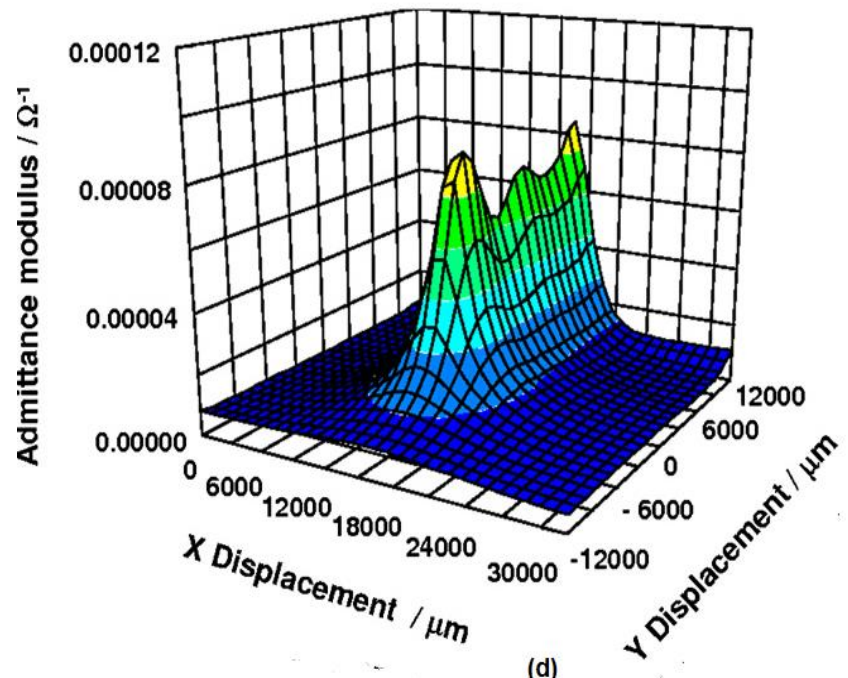

Figura 10 - Representação da resposta obtida pela LEIS para aço zincado em solução de $\mathrm{NaCl} 0.001 \mathrm{M}$ para 1 hora de imersão $(a, c)$ e 12 horas de imersão $(b, d)$ quando a resina epóxi contem argila modificada com inibidor ( $a, b)$ e quando se usa resina epóxi pura (c, d) modificada [Oliver, et A/2010]

Apesar da enorme quantidade de dados que se pode obter pela técnica EIE, além disso, esses dados podem ser interpretados usando ajustes de dados com circuitos elétricos equivalentes, que compreendem um conjunto de elementos como resistores, indutores e capacitores que representam as características físico-elétricas e químicas das interfases consideradas. 
Os espectros de impedância, como dito anteriormente, fornecem informações úteis sobre a evolução tanto das características de proteção dos revestimentos, como também, da cinética do processo de corrosão, em função do tempo de exposição ao meio onde se realizam os ensaios eletroquímicos. Souto et.al (2007) estudaram a variação das propriedades de um revestimento de poliuretano aplicado em aço para diferentes tempos de exposição em $\mathrm{NaCl}$ 0,5 M. Assim, a ação anticorrosiva de algum aditivo e a formação de ferrugem entre outros, são responsáveis pela dependência das medidas com o tempo. Em geral, usam-se os circuitos elétricos equivalentes para dar uma explicação do porquê essas mudanças ocorrem e como ocorrem, associando-os com os parâmetros de resistência e capacitância derivados dos ajustes dos dados de impedância.

Shizhe Song e Lei Han, 2008, monitoraram a degradação do aço carbono imerso em água do mar usando um circuito equivalente simples onde tinham a resistência do eletrólito em série com um capacitor não ideal ou elemento de fase constante, CPE e este em paralelo com a resistência à polarização da interface. Os dados da EIE se ajustam perfeitamente neste modelo simples obtendo erro menores que $2 \%$. Isto demonstrou que, para um sistema simples, um circuito inicial representa os fenômenos que ocorrem na interfase metal-eletrólito. Embora para sistemas revestidos, a complexidade do circuito deva variar.

Di Sarli et Al.(1998) avaliaram o desempenho diante à corrosão do aço carbono revestido e que teve um tratamento de superfície. Ao invés de usar a tradicional resina epóxi, neste estudo utilizaram um elastômero (borracha clorada) e as medidas de impedância foram interpretadas considerando os valores dos diversos circuitos equivalentes que propõem para diferentes tipos de pré-tratamentos que leva o aço carbono, exposto na água do mar. Com esses dados eles conseguiram informações muito importantes relacionadas com o desempenho do revestimento ao longo do tempo (a sua degradação) e a evolução da cinética do processo de corrosão. A Tabela 2 representa todos os circuitos equivalentes que se estudaram e o número de vezes que utilizaram cada um, de acordo com o tipo de pré-tratamento a ser analisado. Dessa 
forma, os autores chegam à conclusão que há dois circuitos que são mais usados pois eles contemplam uma situação clássica tanto dos corpos de prova revestidos com prétratamento. No começo, não há solução penetrante na interfase portanto não está ocorrendo ainda nenhuma reação de corrosão (metal protegido), o segundo circuito sugere que está acontecendo uma difusão mas como indicado na Tabela 2, este circuito não teve a frequência de ajusteê como o circuito três, onde desta vez, o espectro está vendo o que ocorre na interface entre o metal e o revestimento, e também entre o eletrólito e o revestimento e assim por diante.

Estes circuitos equivalente, que estudam a evolução de um filme, ainda não sao muito utilizados nas análises dos revestimentos de autorreparação, mas poderia ser uma ferramenta muito poderosa para estudar a evolução do filme que se esta autorreparando e as caracteristicas resistivas do mesmo comparado com o filme quando não há defeito.

Tabela 2- Circuitos equivalentes para a avaliação da degradação do aço carbono revestido e com diferentes pré-tratamentos. (os números da tabela representam o número de vezes que foi utilizado o circuito para o ajuste durante o teste). [Di Sarli et Al. (1998)]

\begin{tabular}{|l|l|l|l|l|}
\hline Circuito & S & P & PPh & SWP \\
\hline & & & & \\
(a) & 27 & 45 & 62 & 50 \\
\hline
\end{tabular}




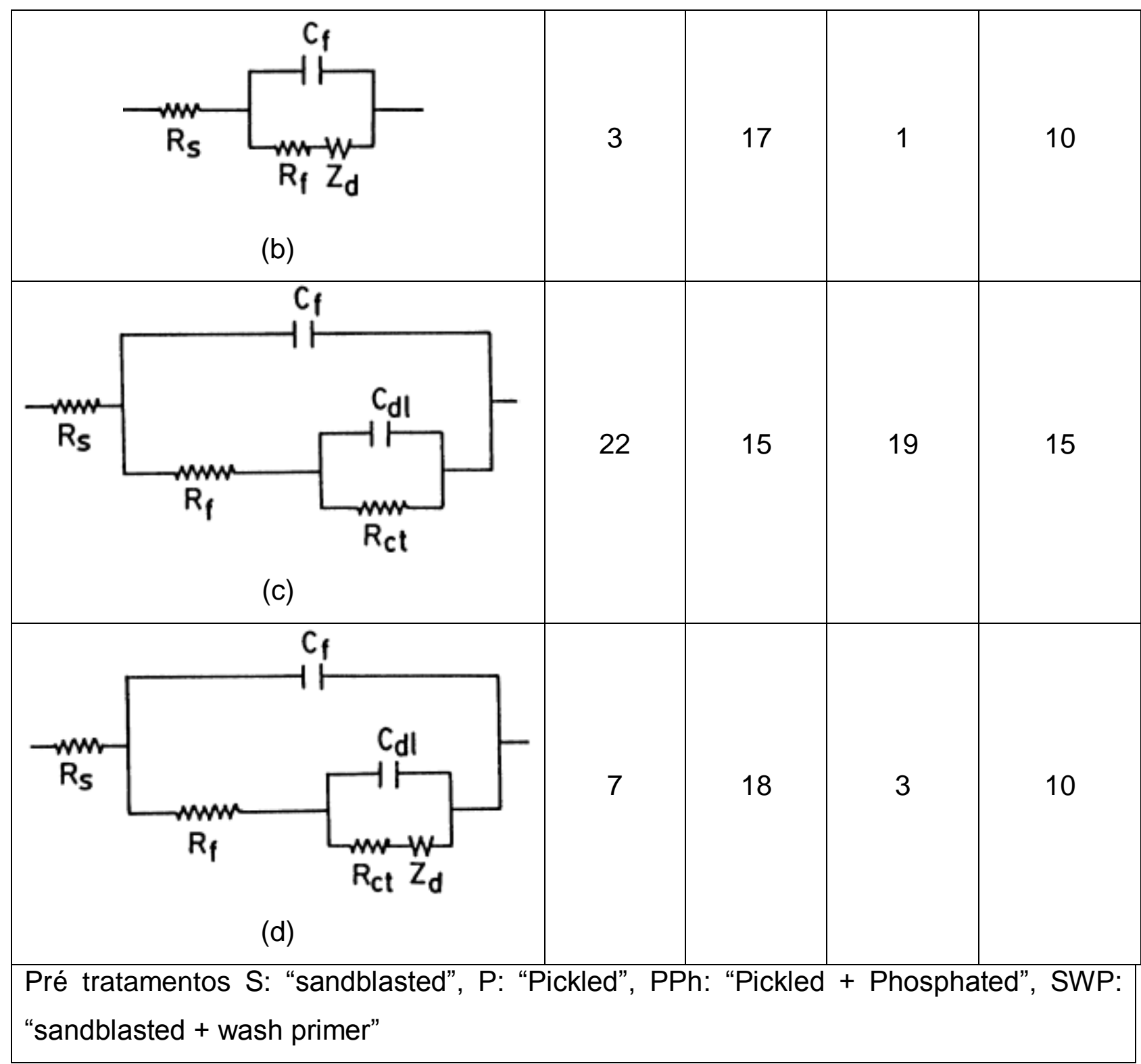

Di Sarli et al. (2004), trabalharam com um sistema de aço revestido com pinturas (acrílica, alquídica, epóxi e vinílica) as quais têm menor porosidade que os revestimentos cerâmicos, e testaram sob imersão em três meios: solução de $\mathrm{NaCl}$, solução de $\mathrm{Na}_{2} \mathrm{SO}_{4}$ e uma mistura destes dois meios. Usando os circuitos equivalentes normalmente propostos (R1(R2Q2(R3Q3))Q1) sendo o elemento $\mathrm{Q}$ (capacitor) um CPE (elemento de fase constante). Ajustaram os dados encontrando interpretações para 
cada elemento o que thes demonstrou que o sistema pintado com resina acrílica apresentou os resultados de menor eficiência e resistência.

\subsection{INFLUÊNCIA DO TIPO DE DEFEITOS PROVOCADOS NOS REVESTIMENTOS DE AUTORREPARAÇÃO}

Em todos os casos onde o substrato é revestido, se considerou a porosidade do filme, sendo esta normalmente homogênea, mas deve ser do nosso interesse saber o que ocorre quando o revestimento apresenta defeitos além da própria porosidade natural, como foi feito por Lee et. al (2012) no estudo do comportamento micromecânico de uma resina epóxi aditivada com microcápsulas quando ocorre uma nanoindentação. Esses defeitos ocorrem de diferentes formas e portanto causam um impacto diferente em cada caso, tornando o sistema mais ou menos eficiente na resistência contra a corrosão. White et.al, (2011) também estudaram a resposta de autorreparação de uma resina epóxi quando submetida à fratura provocada por fadiga.

As pinturas, usadas como recobrimento para a proteção de materiais metálicos, como são as resinas naturais ou sintéticas, são sistemas multicomponentes, pois possuem solventes e aditivos para dar características especiais de acordo com a necessidade. A falha dos revestimentos tem lugar por razões diferentes devida às múltiplas variáveis envolvidas, que vão desde seleção da pintura inadequada até a agressividade do meio externo.

Um revestimento pode sofrer diferentes danos por diversos estímulos causando a perda da função de proteção. Há vários modos de causar o dano aos revestimentos como foi apresentado por Blaiszik et al., (2010) quando estudaram o desempenho dos revestimentos de autorreparação. Alguns dos exemplos mencionados foram: o impacto, a fratura, punção e fadiga entre outros (Figura 11). Os defeitos que podem ser provocados têm diversos formatos que influenciam na avaliação da autorreparação, 
seja por risco com uma ferramenta ou por punção. O objetivo sempre tem sido garantir $100 \%$ a autorreparação, e como menciona Blaiszik, dependendo do tamanho do defeito e do tipo de sistema que se tem, essa eficiência pode variar. No caso dos sistemas baseados nas cápsulas para a autorreparação, estas podem preencher pequenos a moderados volumes de uma maneira muito eficiente.

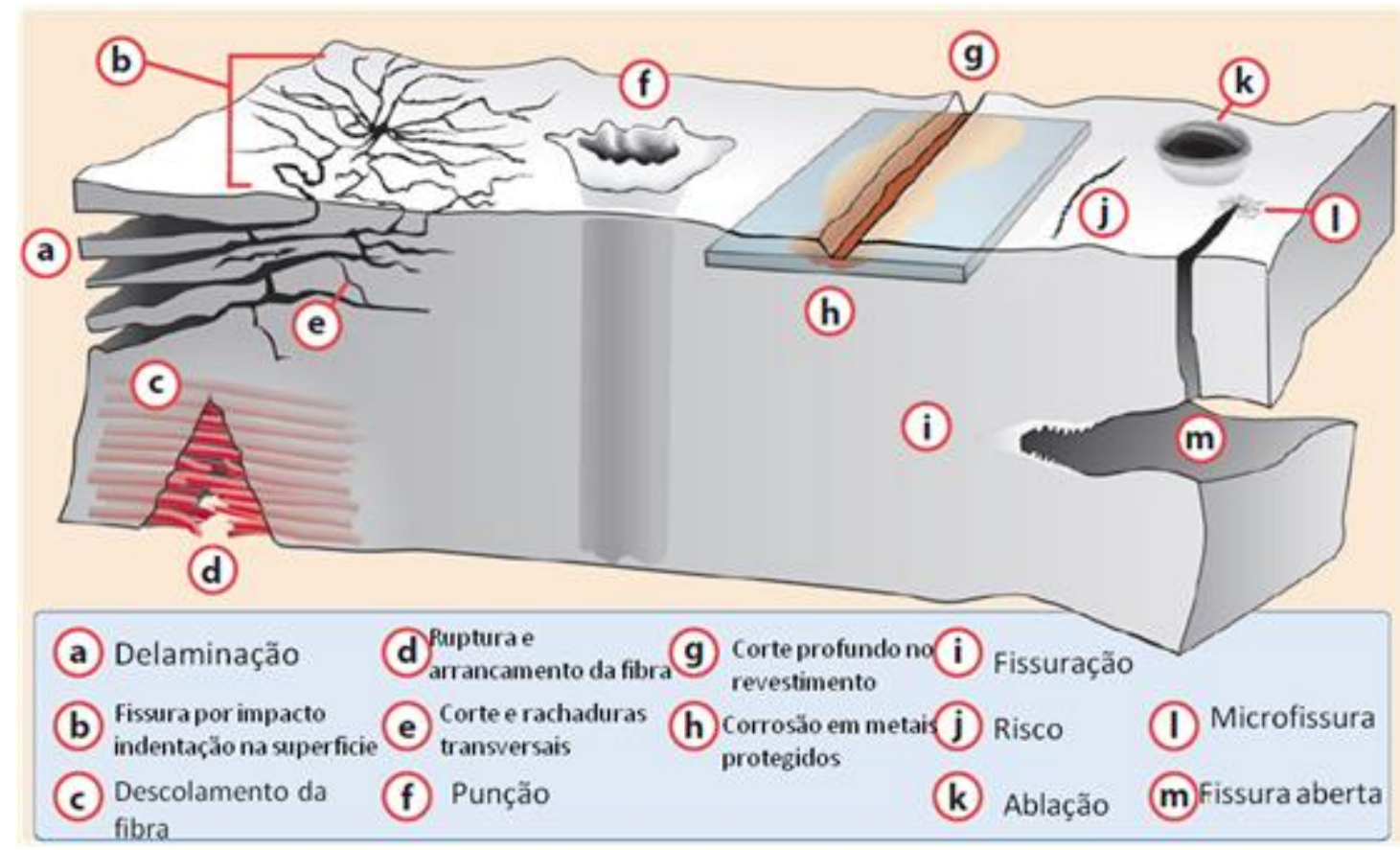

Figura 11- Diferentes tipos de defeitos que podem se formar no revestimento (Blaiszik et al., 2010)

Selvakumar et al (2012) estudaram a autorreparação da resina epóxi aditivada realizando uma fissura manualmente (não discutiram exatamente a ferramenta de corte utilizada) e observaram que no início da fissura a largura era a máxima mas que depois de 90 segundos a fissura foi bem preenchida com o agente de autorreparação que, em contato com oxigênio, formou um filme continuo de proteção. González-García et al (2011) no seu estudo da autorreparação de revestimentos utilizaram uma agulha fina para a confecção do defeito de aproximadamente $75 \mu \mathrm{m} \times 1 \mathrm{~mm}$, e lograram provar que a reparação física do filme no defeito conduz a uma recuperação das propriedades de barreira locais do sistema revestido e proteção subseqüente do substrato. Por outro lado, Stephenson et al (2006) usaram uma navalha de corte ou estilete para avaliar a 
autorreparação de diferentes tipos de microcápsulas aditivadas em resina epóxi, e demonstraram que o agente de autorreparação é liberado quando essas microcápsulas são rompidas, concluindo que mesmo sendo esses defeitos fendas naturais resultantes do envelhecimento do filme ou resultantes de danos mecânico como foi nesse estudo em particular, é possível a autorreparação dos revestimentos contendo microcápsulas. Zheludkevich et al (2003) utilizaram uma agulha metálica afiada, sob carga constante, para o estudo da autorreparação. Os defeitos confeccionados foram apropriados para conseguir demonstrar pela espectroscopia de impedância eletroquímica a autorreparação de um revestimento sobre metais.

O ponto mais importante quanto aos defeitos é que estes possam ser reproduzido nos diferentes corpos de prova revestidos com a tinta aditivada, ou não, com as microcápsulas. Defeitos não reprodutíveis podem levar á resultados não satisfatórios quanto ao efeito de autorreparação.

\subsection{ENSAIOS ACELERADOS DE CORROSÃO: CÂMARA DE NÉVOA SALINA}

O ensaio acelerado mais antigo e mais utilizado para a simulação dos efeitos do meio ambiente é o ensaio acelerado em câmara de névoa salina descrito na norma ASTM B117, que foi originalmente desenvolvido entre 1910-1920 e padronizado em 1939. Este ensaio procura simular as condições encontradas em atmosferas onde está presente o contaminate $\mathrm{NaCl}$ (atmosferas marítimas) através da névoa contínua de solução de cloreto de sódio a uma concentração de $5 \%(\mathrm{~m} / \mathrm{m})$ e temperatura de $35^{\circ} \mathrm{C} \pm 2^{\circ} \mathrm{C}$. O pH da solução varia entre 6,5 e 7,2 e a umidade relativa é de $100 \%$. As placas são colocadas em posição vertical, mas com uma inclinação de $30^{\circ}$ da vertical.

Gang Kong e colaboradores (2011) estudaram o efeito de reparação do revestimento à base de silicato para aço galvanizado. Aplicando o teste de névoa salina onde os corpos de prova foram expostos a uma solução de $5 \% \mathrm{NaCl}$ com um pH de 6.5 e $35^{\circ} \mathrm{C}$. 
Dos resultados obtidos, os autores concluíram que foram liberados ânions de silicato contendo grupos $\mathrm{Si}-\mathrm{OH}$ nas fissuras pois houve uma reação durante a exposição à névoa salina criando-se redes entre os grupos Si-O-Si e Si-O-Zn, e foi esta reticulação que os pesquisadores consideraram como a habilidade de autorreparação.

Dhirendra et Al. (2008) mostraram como foi avaliado o desempenho do óleo de linhaça como agente autorreparador por meio de ensaios acelerados com a câmara de nevoa salina, conseguindo diferenciar as placas com revestimento (resina epóxi) sem aditivar daquelas que possuíam microcápsulas, as quais quebraram e liberaram o óleo de linhaça. Assim, se conseguiu provar também a formação do filme pela polimerização oxidativa com o oxigênio do ar, portanto, evitando corrosão. Os corpos de prova submetidos ao ensaio acelerado começaram a mostrar uma leve diferença após 24 horas, mas após 48 horas de exposição, a diferença já era significativa (Figura 12)

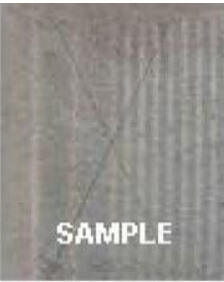

24 HOURS

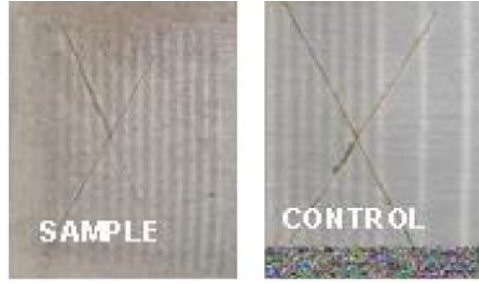

48 HOURS

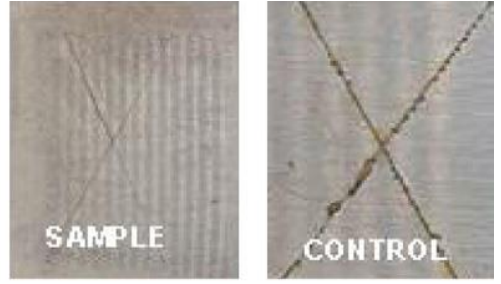

72 HOURS

Figura 12- Evolução da corrosão por exposição na câmara de névoa salina para revestimento aditivado com microcápsulas contendo óleo de linhaça(Dhirendra et al., 2008);

\subsection{FORMAÇÃO DO FILME AUTORREPARADOR A PARTIR DE ÓLEO DE LINHAÇA}

O óleo de linhaça é conhecido pelas suas propriedades de secante e endurecedor quando exposto ao ar, por isto é bem usado na indústria de pinturas. Funciona como agente auto-reparador, pois possui boas propriedades de aderência e formação de películas. Essa formação de película é facilitada pela oxidação atmosférica. Óleo de linhaça é um liquido amarelado derivado de sementes da planta de linho (Linum 
usitatissimum, Linaceae) e é um ingrediente importante em uma grande quantidade de tintas a óleo e vernizes. Em alguns casos, é um liquido com elevada viscosidade, mas que normalmente é usado como diluente para tinta a óleo para facilitar a formação de uma película uniforme, homogênea e dá as características de acabamento como é o brilho e acabamento liso.

O típico óleo de linhaça contém triglicérides a partir dos ácidos graxos tais como o ácido oléico, o ácido linoléico e o ácido linolênico. O alto conteúdo desses ácidos é o que garante as propriedades secantes do óleo. Estes ácidos são moléculas formadas por cadeias de 18 carbonos, mas que possuem uma, duas e três -respectivamenteligações duplas entre carbonos ou chamados também carbonos insaturados. São nessas insaturações onde ocorre a reação com o oxigênio do ar e dando como resultado a formação de uma rede polimérica.

A figura 13 é uma representação da triglicéride formada por estes ácidos.

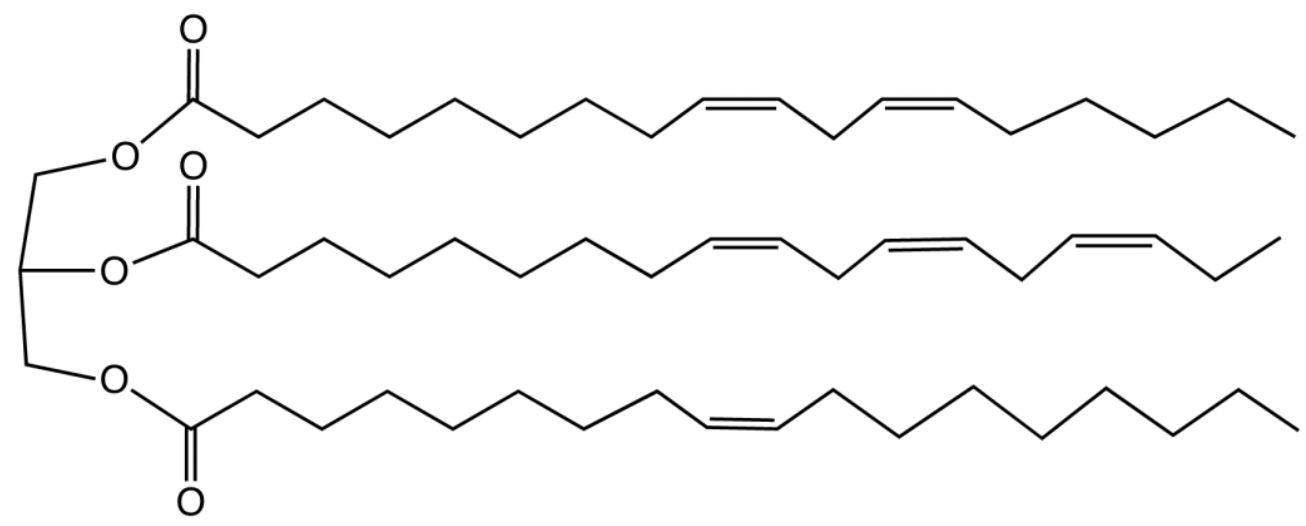

Figura 13- Representação do óleo de linhaça.

O estudo feito por Dlugogorski et.al (2011) foram analisadas as reações de oxidação do óleo de linhaça e encontraram que o ácido linolênico é o mais reativo, depois o linoléico e por último o oléico. Deste resultado concluíram que o fato de ter três insaturações na cadeia, fazia com que o ácido linolênico fosse o mais reativo por tanto permitisse maior entrecruzamento das moléculas para a formação da rede polimérica. 
Assim mesmo, no estudo feito por Oscar Chiantore e Massimo Lazzari (1999) sobre a degradação oxidativa e secante do óleo de linhaça, encontraram que a absorção de oxigênio leva à formação de peróxidos (hidroperóxidos como cicloperóxidos) os quais criam estruturas interligadas o que é chamado como polimerização do óleo de linhaça.

O mecanismo de secagem do óleo de linhaça detalhado por estes autores esta representado pelo seguinte fluxograma (Figura 14) e como exemplo a representação do mecanismo para o ácido (Figura 15)

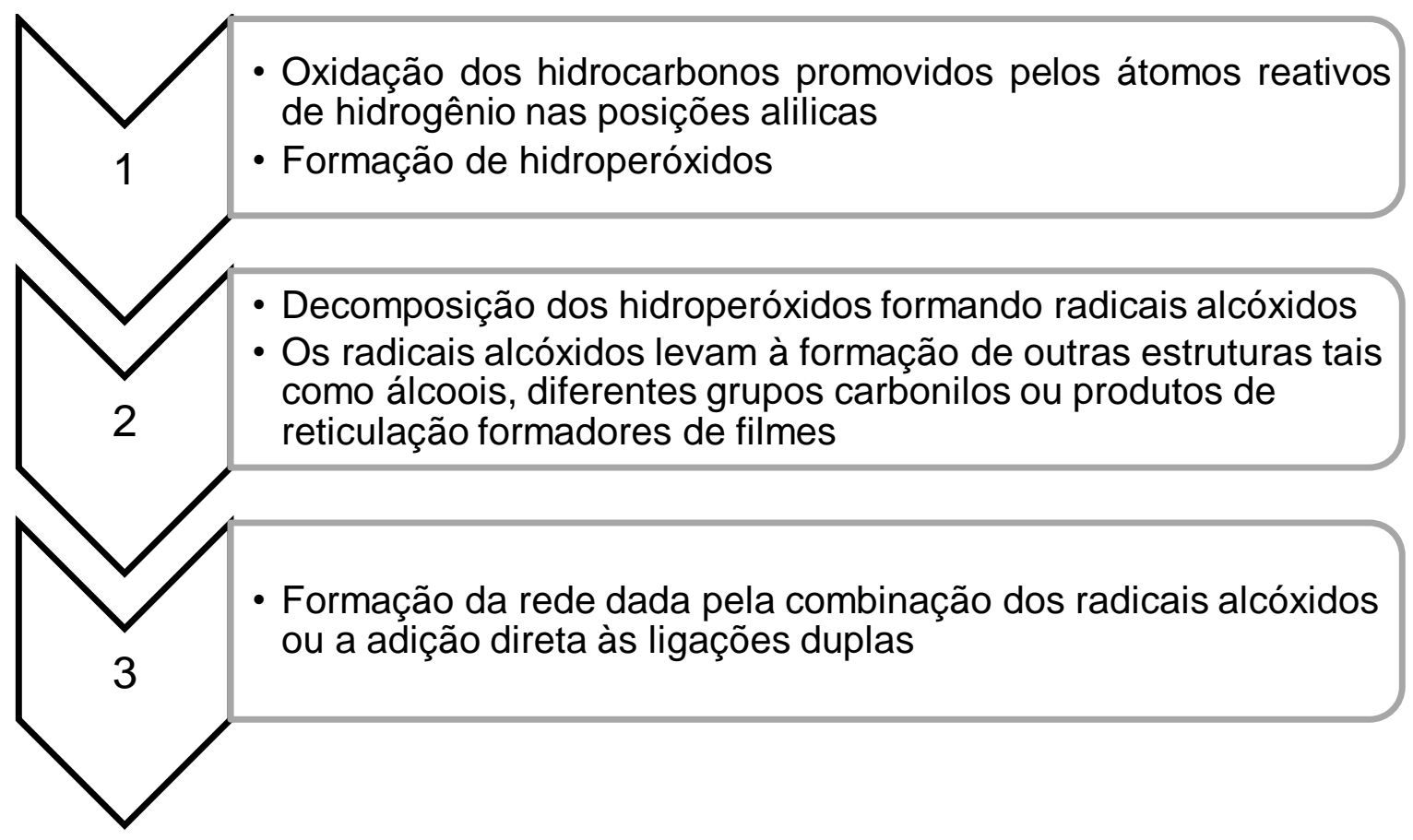

Figura 14 - Fluxograma do mecanismo.de oxidação do óleo de linhaça para a formação de filme 

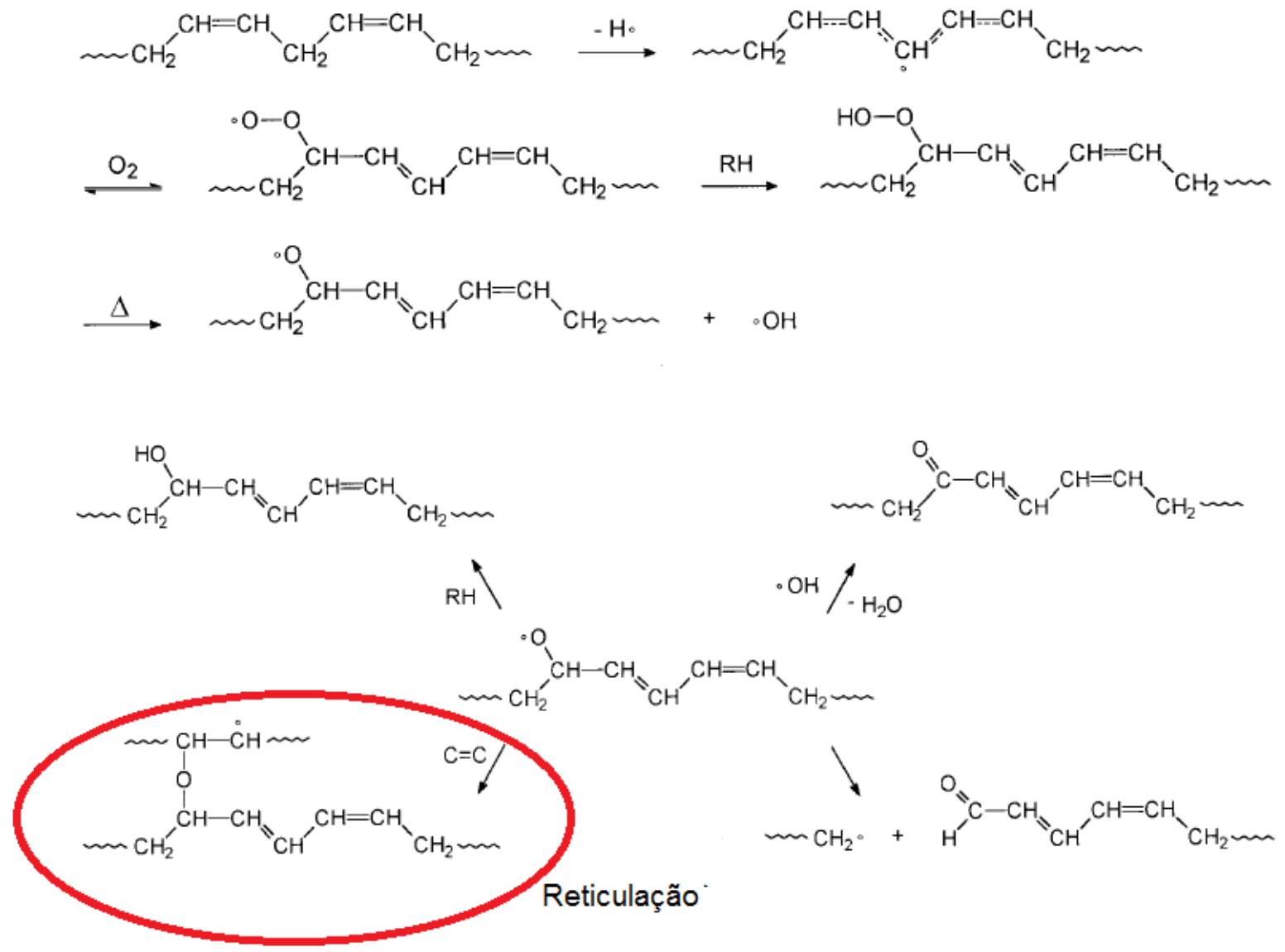

Figura 15 - Ilustração do mecanismo para a formação de estruturas reticuladas e outras estruturas tais como álcoois, o diferentes grupos carbonilos. [Chiantore e Lazzari (1999)] 


\section{MATERIAIS E MÉTODOS}

\subsection{SUBSTRATO UTILIZADO}

O substrato utilizado foi um aço carbono IF (interstitial free) da empresa brasileira Brasmetal. A composição química do aço e as propriedades mecânicas são apresentadas na tabela 3 .

Tabela 3 - Características químicas e mecânicas do aço carbono IF. Dados fornecidos pelo fabricante: Brasmetal

Composição química

\begin{tabular}{|l|l|l|l|l|l|l|l|}
\hline $\mathrm{C}(\%)$ & $\mathrm{Mn}(\%)$ & $\mathrm{Si}(\%)$ & $\mathrm{P}(\%)$ & $\mathrm{S}(\%)$ & $\mathrm{Al}(\%)$ & $\mathrm{Ti}(\%)$ & $\mathrm{N}(\%)$ \\
\hline 0,0024 & 0,0024 & 0,0050 & 0,0120 & 0,0080 & 0,0430 & 0,0390 & 0,0017 \\
\hline
\end{tabular}

Propriedades mecânicas:

\begin{tabular}{|l|l|l|l|l|}
\hline $\begin{array}{l}\text { Limite de } \\
\text { Resistência } \\
\left(\mathrm{N} / \mathrm{mm}^{2}\right)\end{array}$ & $\begin{array}{l}\text { Limite de } \\
\text { Escoamento } \\
\left(\mathrm{N} / \mathrm{mm}^{2}\right)\end{array}$ & $\begin{array}{l}\text { Along (Lo 80 } \\
\mathrm{mm})\end{array}$ & $\begin{array}{l}\text { Indice de } \\
\text { Encruamento } \\
(\mathrm{n})\end{array}$ & $\begin{array}{l}\text { Rugosidade }(\boldsymbol{\mu}) \\
(\mathrm{Ra})\end{array}$ \\
\hline 290 & 160 & $41.5 \%$ & 0.23 & 1.40 \\
\hline
\end{tabular}

O tamanho dos corpos de prova para a avaliação do efeito self-healing foi de $5 \mathrm{~cm} \mathrm{x}$ $5 \mathrm{~cm} \times 1 \mathrm{~mm}$. 


\subsection{CARACTERÍSTICAS DO ÓLEO DE LINHAÇA UTILIZADO COMO AGENTE DE AUTORREPARAÇÃO.}

O óleo de linhaça foi escolhido como agente autorreparador, pois possui boas propriedades de aderência e formação de películas. e dá as características de acabamento como é o brilho e acabamento liso.

O óleo de linhaça trabalhado neste projeto foi o óleo de linhaça polimerizado da marca Gato Preto, que possui as mesmas características do óleo de linhaça refinado, porém tem uma viscosidade maior, parecida com as tintas a óleo e, o mais importante é um tempo de secagem menor que o do óleo de linhaça tradicional.

\subsection{TRATAMENTO DA SUPERFÍCIE DO SUBSTRATO}

O aço carbono recebido vem com uma camada de óleo protetivo que o protege contra a corrosão durante o transporte e manuseio para corte. É um óleo bastante aderente que precisa ser removido, porém não foi muito eficiente porque as placas já apresentavam os primeiros sinais de ataque corrosivo. $O$ tratamento seguido foi primeiramente um desengraxamento com xileno, depois uma decapagem com uma solução de $\mathrm{HCl} 0.1 \mathrm{M}$ inibido com benzotriazol para remover os produtos de corrosão. O seguinte passo fundamental foi o desengraxe alcalino dos corpos de prova. Na preparação do substrato foi utilizado um desengraxante alcalino comercial MAX FERZNL 70. A concentração dessa solução de desengraxante alcalino foi de $50 \mathrm{~g} / \mathrm{L}$, utilizado a $60{ }^{\circ} \mathrm{C}$ durante dez minutos. Após o desengraxe, os corpos-de-prova foram enxaguados e lixados com lixas d'agua de carbeto de silício de granas 120, 320, 400 e600 para garantir uma superfície totalmente homogênea para não interferir na aderência do revestimento de epóxi tipo "clear" e nem nas medidas de impedância. Os corpos-de-prova foram lavados com água depois com etanol e finalmente com acetona e depois secos com jato de ar 
quente. Para manter os corpos-de-prova protegidos até a aplicação do revestimento, estes foram guardados em um dessecador contendo sílica gel.

\subsection{PREPARAÇÃO DAS MICROCÁPSULAS}

Para a preparação das microcápsulas foram seguidas duas metodologias: a metodologia do trabalho de Dhirendra et al 2008 baseado no processo original proposto por (Brown, et al., (2003). A segunda, baseada no processo feito por Ting et al., (2010).

A diferença entre as duas metodologias é que a primeira (original), se inicia com a preparação da emulsão e depois se faz reagir o formaldeído com a uréia para assim conseguir fazer as microcápsulas, enquanto o segundo método prepara o material que atuará como parede das microcápsulas em separado, como um pré-polímero, que logo é adicionado na emulsão e este recobre as micelas transformando-as em microcápsulas.

\subsubsection{Preparação da emulsão óleo de linhaça em solução aquosa}

Os materiais utilizados foram: Uréia: $5 \mathrm{~g}$, formaldeído $37 \%: 12,67 \mathrm{~g}$, solução de PVA 10\%: $10 \mathrm{ml}$ (o PVA atua como estabilizante de suspensão, ou seja ajuda na estabilidade das micelas), solução de $\mathrm{HCl} 0,1 \mathrm{M}$ ou TEA (trietanolamina) para acerto do $\mathrm{pH}$ e $60 \mathrm{ml}$ de óleo de linhaça e $260 \mathrm{ml}$ de água destilada. Adicionalmente, o processo seguido para a primeira metodologia se apresenta no fluxograma da Figura 16. As quantidades de resorcinol e cloreto de amônio são de $0,5 \mathrm{~g}$ cada um. 


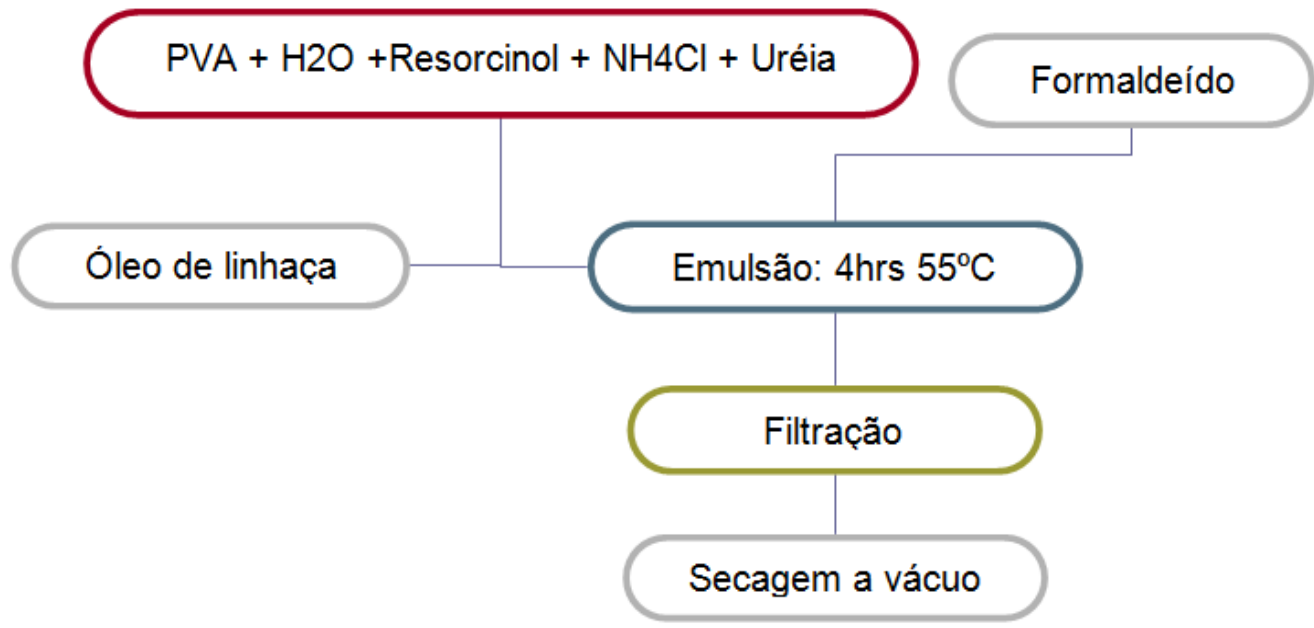

Figura 16- Processo de preparação das microcápsulas de uréia-formaldeído contendo óleo de linhaça pelo método I

Misturam-se inicialmente a água e o PVA por dois minutos sob agitação, em seguida se adiciona o resorcinol (0,5 g), o cloreto de amônio e aos poucos a uréia. Nesta etapa deve-se controlar o pH em 3.5 usando uma solução de $\mathrm{HCl}$ 0,1 M. O objetivo de manter a mistura com pH baixo é para quando se adicionar o óleo de linhaça, este se emulsione e também porque a polimerização da uréia e formaldeído exige $\mathrm{pH}$ ácido. Sob agitação por 10 minutos, se adicionam os $60 \mathrm{ml}$ do óleo de linhaça e se obtêm uma emulsão de óleo em água e imediatamente se começa a aquecer e se adiciona a solução de formaldeído $37 \%$. O aquecimento deve ser feito até $55^{\circ} \mathrm{C}$, controlando essa temperatura durante 4 horas. Após a polimerização, deixa-se esfriar à temperatura ambiente para passar à etapa seguinte de filtração.

A segunda metodologia de obtenção das cápsulas se apresenta na Figura 17, onde as quantidades utilizadas dos reagentes são iguais às mencionadas no método um. 


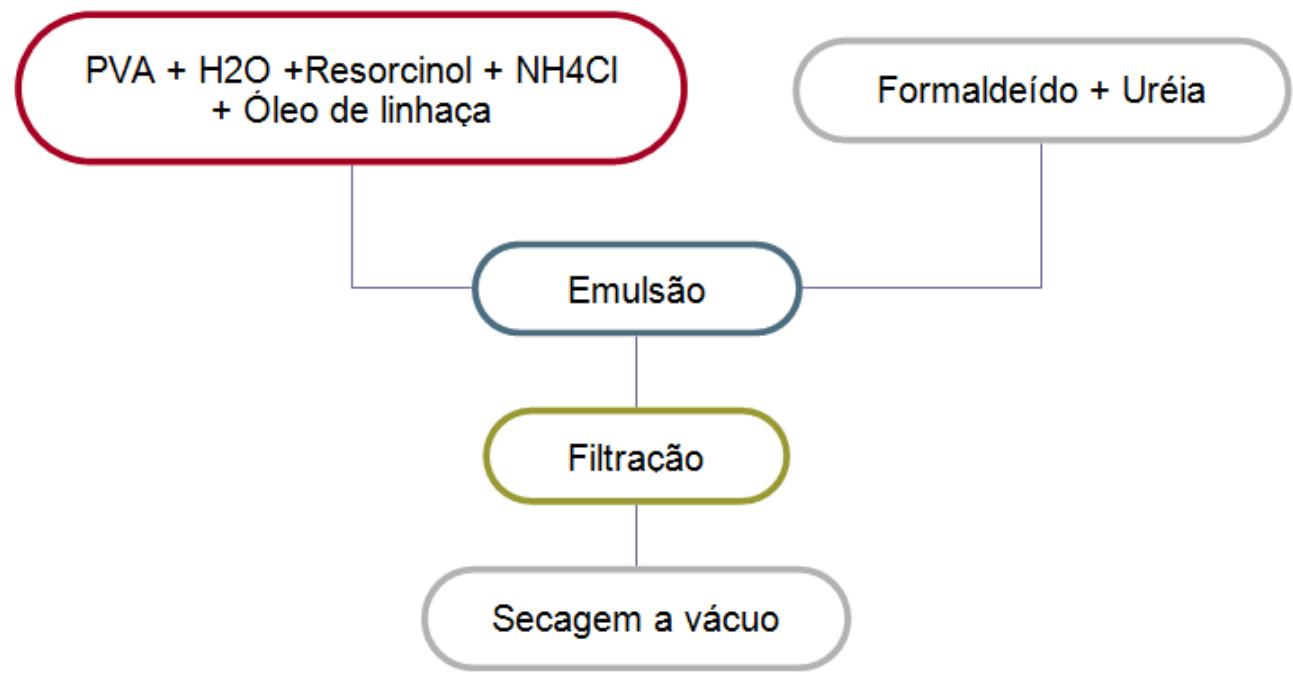

Figura 17- Processo de preparação das microcápsulas de uréia-formaldeído contendo óleo de linhaça pelo métodoll

A diferença entre os métodos I e II é que no método II se prepara um pré-polímero de uréia-formaldeído (UF) agitando por uma hora, entre $80-90^{\circ} \mathrm{C}$, uma solução de formaldeído $37 \%$ com uréia mantendo o pH da mistura ao redor de 8-9, adicionando TEA. À parte se prepara uma emulsão de óleo em água à temperatura ambiente e sob agitação se agrega o pré-polímero de UF, em seguida se aumenta a temperatura até 70 ${ }^{\circ} \mathrm{C}$ por 3 horas. Deixa-se esfriar à temperatura ambiente para em seguida recuperar as microcápsulas, por filtração.

\subsubsection{Filtração sob vácuo}

Para a recuperação das microcápsulas, se usou papel filtro qualitativo de porosidade de 2,5 $\mu \mathrm{m}$. Este papel de filtro é colocado em um funil de Buchner montado sobre um kitassato com saída lateral para conexão à bomba de vácuo.

A emulsão das microcápsulas é adicionada aos poucos e lavada com água e enxaguada com xileno, para a remoção de impurezas e reagentes não utilizados. Esta lavagem foi feita em duas etapas. 


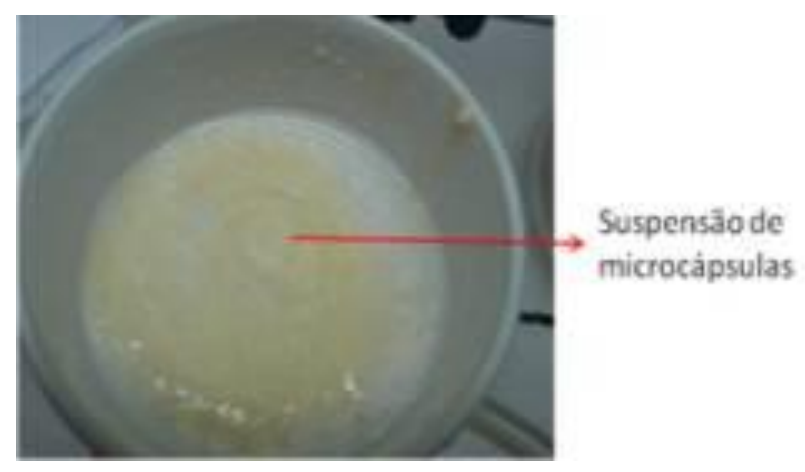

Figura 18- Suspensão de microcápsulas usada no processo de lavagem e filtração a vácuo.

\subsection{CARACTERIZAÇÃO DAS MICROCÁPSULAS}

\subsubsection{Avaliação das microcápsulas ao microscópio ótico}

Para identificar se as microcápsulas se formaram ou não, pelos processos descritos anteriormente, lâminas de vidro foram preparadas com amostra da massa de microcápsulas previamente filtrada. Para a visualização das microcápsulas, a massa filtrada é dispersa em um solvente (xileno) para ser gotejado nas lâminas de vidro.

\subsubsection{Caracterização das Microcápsulas por MEV}

Para o exame ao microscópio eletrônico de varredura, MEV, as amostras de suspensão de microcápsulas devem ser gotejadas sobre placas metálicas pequenas previamente lixadas com lixas de granas de 120, 320, 400, 600, 1200, 2500 e 4000 e depois polidas com pasta de diamantes de 3 e 1 micron até obter um acabamento especular. Este procedimento é fundamental, pois no MEV o nível de detalhe é alto e qualquer risco na placa ou sujeira pode levar a interpretações erradas. Além disso, a superfície onde 
estão as microcápsulas precisa ser condutora, para evitar a saturação da imagem provocada pelo excesso de elétrons que não escoam do porta-amostras. As micrografias das cápsulas obtidas foram obtidas num microscópio eletrônico Philips modelo XL30 acoplado a um espectrômetro de energia dispersiva de raios X(EDS), utilizando a voltagem do feixe de $20 \mathrm{keV}$ e corrente de $53 \mathrm{~mA}$ e $150 \mathrm{~mA}$. Essas imagens por MEV foram realizadas no Departamento de Engenharia Metalúrgica e de Materiais da EPUSP

\subsection{PREPARAÇÃO DO REVESTIMENTO TIPO "CLEAR" A BASE DE RESINA EPÓXI}

Um revestimento tipo "clear" pode ser considerado como um "primer" ou primeira camada que se adere ao metal, mas a diferença entre "primer" e "clear" é que o "clear" não possui pigmentos ou outros aditivos. De acordo ao procedimento seguido por Dhirendra et al 2008 se usou uma resina epóxi com um EEW (Epóxi EquivalentWeight) entre 180 e 194 e um endurecedor a base de amina com o valor de AHEW (Amino HydrogenEquivalentWeigth) de 110. As matérias primas foram gentilmente doadas pela Dow Química (resina epóxi) e a Air Products doou o endurecedor. Para facilitar a

aplicação desse clear foi feita a diluição da resina epóxi em uma proporção de 4:1 em volume com uma mistura de solventes (xileno-butanol)

\subsubsection{Preparação do "clear" sem aditivação}

Os valores de EEW e AHEW são fundamentais para a formulação do clear, pois existe uma relação entre eles. Tanto com o EEW como com o AHEW se estabelecem as quantidades necessárias para fazer a blenda equimolar segundo a equação 1. 


$$
\frac{E P O ́ X I(m o l) * M(g)}{E E W(g)}=X(m o l)
$$

Sendo uma mistura equimolar então para calcular a quantidade de endurecedor segue a seguinte equação 2 .

$$
\frac{X(m o l) * A H E W(g)}{A M I N A(m o l)}=B(g) \text { Eq. } 2
$$

Onde $M(g)$ quantidade em massa que se quer usar de resina epóxi, $X(\mathrm{~mol})$ a quantidade equivalente em moles de resina epóxi, $B(g)$ quantidade em massa de endurecedor.

\subsubsection{Preparação de revestimento tipo "clear" aditivado com 5\% e 10\% em massa de microcápsulas}

Um revestimento tipo clear é aquele que só contem a resina e diluente, não contendo qualquer outro aditivo.

Para a aditivação do clear preparado previamente, se pesaram 5 partes em massa de microcápsulas por cada 100 partes em massa do clear quando a aditivação é de 5\%, e 10 partes de microcápsulas em 100 partes do clear para $10 \%$ de aditivação. Tendo a quantidade de microcápsulas a ser adicionada ao clear, estas são dispersadas em um pouco da solução de diluente (xileno:butanol 3:1) utilizado para a diluição da resina epóxi. Isto com o fim de garantir melhor dispersão das microcápsulas na resina epóxi. Depois de ter a resina diluída e as microcápsulas incorporadas, o endurecedor é acrescentado lentamente e sob agitação lenta e ocorre a reação entre a resina epóxi e o endurecedor. 


\subsection{TÉCNICAS PARA A APLICAÇÃO E AVALIAÇÃO DO REVESTIMENTO TIPO "CLEAR"}

\subsubsection{Mecanismos de aplicação do revestimento}

Para aplicação do revestimento tipo clear serão consideradas três técnicas. As técnicas são: pincel (manual), dipcoating e extensor (manual). Para qualquer uma das técnicas de aplicação é importante lembrar que a superfície do aço deve estar perfeitamente limpa, para garantir uma camada homogênea e totalmente aderida ao metal.

Para a aplicação com pincel deve-se ter a precaução de não deixar marcas do pincel, pois isso pode gerar variações importantes na espessura e nas medidas eletroquímicas. Para a aplicação por dip coating a velocidade de imersão deve ser a mesma que a de saída do corpo-de-prova e igual a $10 \mathrm{~cm}$ por minuto, e o tempo que o corpo-de-prova permanece imerso deve ser no máximo um minuto para evitar endurecimento da resina.

Para a aplicação com o extensor se deve garantir limpeza absoluta do mesmo, pois, qualquer sujeira que houver, esta vai criar marcas no filme, diminuindo a espessura desejada e até pode deixar alguma parte da superfície do metal exposta ao meio ambiente e esta poderá corroer.

\subsubsection{Confecção de defeito no revestimento}

Para a avaliação do efeito self-healing é necessário criar um defeito no revestimento para permitir que as microcápsulas se quebrem e liberem o agente de autorreparação, que neste caso particular, é óleo de linhaça. 
Neste estudo se usaram dois métodos: O primeiro usando um estilete para fazer um risco profundo e linear; o segundo método foi por meio de um durômetro para teste de dureza de polímeros em que se obtêm um defeito circular. Os riscos realizados com o estilete sempre foram feitos de cima para baixo, com o objetivo de diminuir qualquer variação tanto na força como na linearidade do defeito. Os riscos usando o durômetro foram feitos sob a mesma força de carga $(50 \mathrm{~N})$ para garantir a total penetração do indentador da ferramenta através do revestimento clear e atingindo o metal.
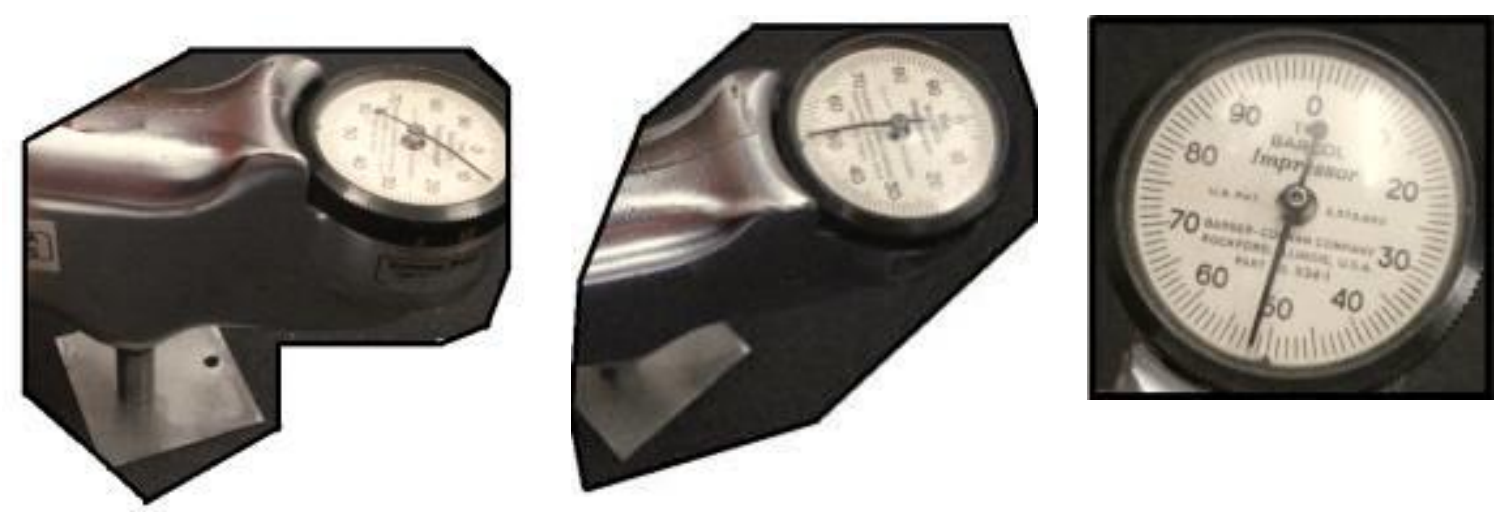

Figura 19- Indentador de durômetro de plásticos marcando carga de 50N durante execução do defeito.

Os defeitos foram confeccionados em todos os corpos de prova ao mesmo tempo (tempo 0h) e levados a avaliação pela técnica de espectroscopia de impedância eletroquímica a cada 24 horas, começando desde o tempo 0 h.

\subsubsection{Avaliação do efeito autorreparador (self-healing) do revestimento tipo "clear" pela técnica de espectroscopia de impedância eletroquímica.}

A técnica de espectroscopia de impedância eletroquímica foi utilizada para avaliar de forma quantitativa a autorreparação do filme com o tempo. Com a EIE se obtêm gráficos, como os diagramas de Bode, que dão informação sobre o módulo da impedância IZI ou do ângulo de fase, com a freqüência 
A célula utilizada é uma célula de área exposta de $3,3 \mathrm{~cm}^{2}$ em um sistema de três eletrodos.

- Eletrodo de trabalho: O substrato de aço carbono revestido com o "clear"

- Eletrodo de referência: Eletrodo de $\mathrm{Ag} / \mathrm{AgCl}$ em $\mathrm{KCl}$ saturado

- Contra-eletrodo: folha de platina de área aproximada a $13 \mathrm{~cm}^{2}$ em formato de L; esse formato em $L$ foi determinado para garantir maior aproximação entre os três eletrodos.

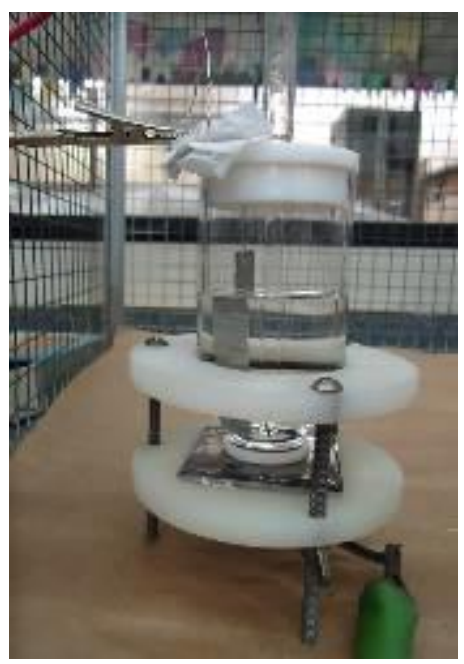

Figura 20-Montagem da célula com três eletrodos para realização de medidas de EIE.

Para a realização das medidas de impedância se trabalhou com um potenciostatogalvanostato $E G \& G / P A R$, modelo 273 e um analisador de freqüênciaSolartron modelo 1255B com ajuda do software Power Suite para a determinação do potencial de circuito aberto, Eoc e dos softwares Zplot e Zview para a realização das medidas de impedância e o seu tratamento, respectivamente.

As condições para as medidas de impedância eletroquímica são as seguintes: utilizouse uma faixa de freqüência de $0,05 \mathrm{~Hz}$ até $50.000 \mathrm{~Hz}$ com uma amplitude de perturbação do potencial de $10 \mathrm{mV}$ rms e 10 medidas realizadas por cada década logarítmica de freqüência. Primeiramente foi feita a medida de Eoc com o tempo e depois da estabilização do potencial de circuito aberto após 120 minutos de imersão, foram realizadas as medidas de impedância eletroquímica. 


\subsubsection{Avaliação do efeito autorreparador (self-healing) do revestimento tipo "clear" utilizando ensaios na câmara de névoa salina}

Este teste foi realizado em um equipamento de testes industriais acelerados de corrosão da BASS Equipamentos Ltda, modelo USC-ISO-PLUS-2010. Este teste consiste na exposição de umas chapas de $10 \mathrm{~cm} \times 15 \mathrm{~cm} \times 1 \mathrm{~mm}$ previamente desengraxadas, revestidas numa das faces com o revestimento tipo "clear" com e sem à aditivação das microcápsulas e o resto da peça pintada com uma pintura anticorrosiva industrial da Sherwin Williams. Já com os corpos de prova curados por sete dias, um defeito de sete $\mathrm{cm}$ de comprimento foi feito sobre a parte protegida com o revestimento tipo "clear" e introduzidos na câmara de névoa salina a cada 24 horas, para assim poder avaliar a formação do filme autorreparador. A concentração da solução salina de $\mathrm{NaCl}$ utilizada neste teste foi de $5 \%$ e uma pressão de 1,0 Kgf no ejetor de névoa. Os corpos de prova foram deixados à exposição da névoa salina por uma semana. 


\section{RESULTADOS E DISCUSSÃO}

\subsection{OBTENÇÃO DE MICROCÁPSULAS}

\subsubsection{Otimização do processo de preparação das microcápsulas}

As microcápsulas foram obtidas de acordo com o método I descrito no capítulo de materiais e métodos, mas com uma diferença em relação ao método proposto por Dhirendra et al 2008. Ao preparar a emulsão pelo método I, se percebeu que a emulsão não se mantinha estável após o tempo de agitação e ocorria uma rápida separação de fases. Foi necessário então usar um surfactante que ajudasse na estabilidade da emulsão. Para isso, se testaram dois surfactantes, Renex-95 e Silwet 7607. Para esse teste se preparou uma emulsão de óleo em água nas proporções que se utilizariam no processo (100 partes de água para 60 de óleo) e se começou com uma quantidade de surfactante de 1.5 partes/100 partes de água e se agitou por 5 minutos. Após cinco minutos, parava-se de agitar e se media o tempo para que as fases começassem a se separar; assim foi feito aumentando-se a concentração do surfactante para determinar qual era a concentração ideal. Para ter maior precisão, os experimentos foram realizados em triplicata (os subíndices "p" representam o número do teste) 


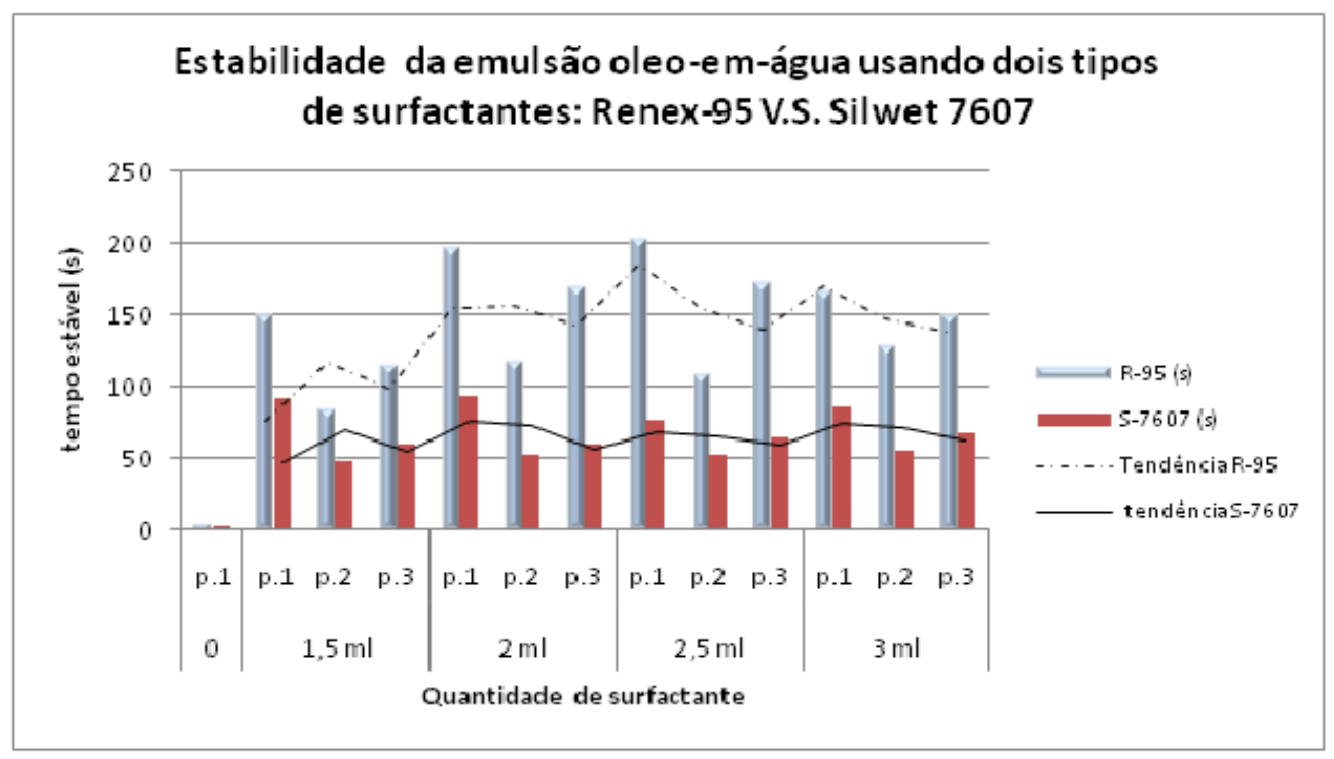

Figura 21- Tendência da variação da estabilidade de uma emulsão óleo-em-água com a quantidade e tipo de surfactante.

Com este experimento se determinou que, apesar do R-95 apresentar maior variação no tempo de estabilidade, para todos os casos, sempre apresentou maior tempo de estabilidade, o qual é muito importante, pois permite que as micelas formadas durante a agitação tenham um tempo de vida maior e portanto a possibilidade de maior quantidade de microcápsulas serem formadas. Por outro lado, quando não há surfactante $(0 \mathrm{ml})$ o tempo de estabilidade é muito curto e por isso não se conseguia a polimerização das microcápsulas, por não haver micelas suficientes para criá-las. Esta falta de estabilidade pode indicar ao mesmo tempo, que a solução de PVA 10\% não é suficientemente efetiva para garantir a estabilidade das micelas . 


\subsubsection{Caracterização das Microcápsulas}

Foi feito um monitoramento do número e tamanho das microcápsulas, com um microscópio ótico, durante o tempo de polimerização obtendo, assim, o registro do processo de formação das microcápsulas ao longo do tempo.

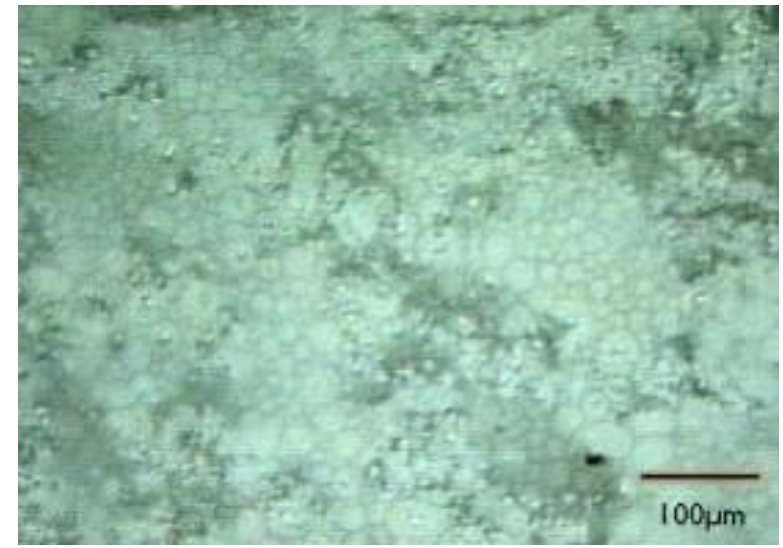

(a)

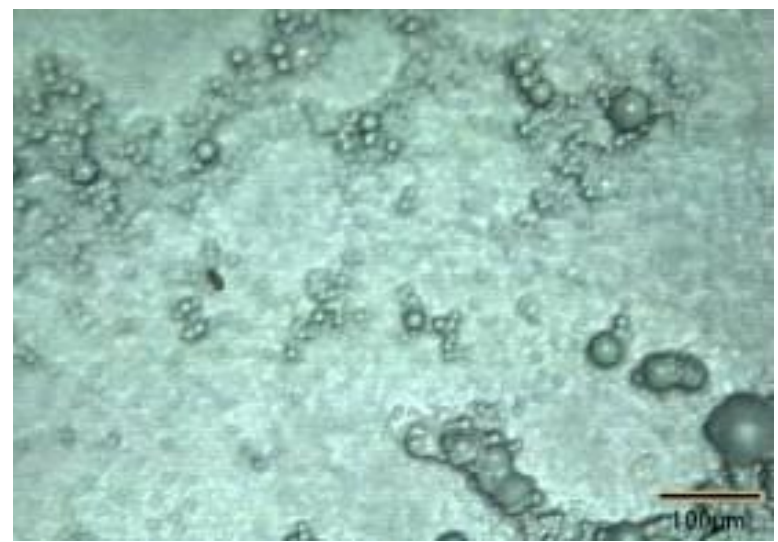

(c)

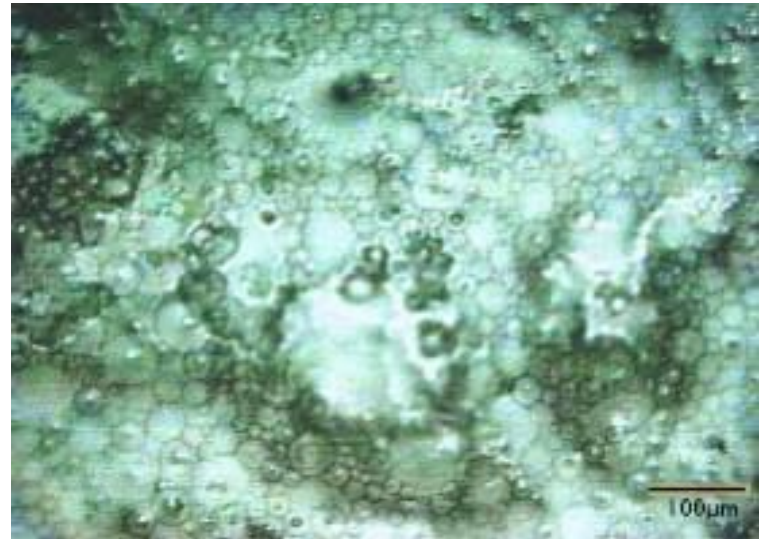

(b)

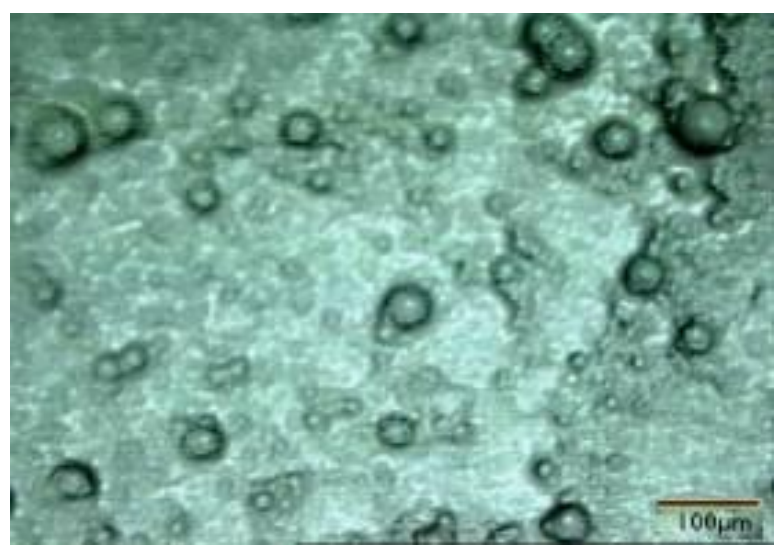

(d)

Figura 22- Imagens obtidas ao microscópio ótico depois de (a) uma hora , (b) duas horas, (c) três horas e (d) quatro horas de polimerização.

As imagens da figura 22 revelam que depois de uma hora de reação, micelas que se tornam microcápsulas começam a se formar, mas ainda não possuem uma parede sólida estável e ainda se aglomeram umas com as outras. A partir de três horas de reação de polimerização as microcápsulas são formadas e possuem uma parede solida e estável. 
Por outro lado, não foi possível a obtenção das microcápsulas pelo método II de acordo com o descrito por Ting, et al., 2010 , pois a emulsão com o pré-polímero não se manteve estável e, mesmo adicionando os surfactantes Renex-95 e o Silwet 7607, não se formaram microcápsulas bem definidas.

Imagens obtidas por MEV foram obtidas de acordo com o procedimento descrito anteriormente. Pode-se ver na figura 23 (a) uma microcápsula pequena (cerca de $10 \mu \mathrm{m})$, bem formada e de características robustas o que garante uma maior estabilidade da mesma. Na figura 23 (b), uma microcápsula instável, pois se quebrou antes do tempo. A figura 23 (c) mostra o grupo de microcápsulas formadas, mas ainda encontra-se material restante da polimerização. Obteve-se uma microcápsula maior (d) com mais de $100 \mu \mathrm{m}$ de diâmetro, mas também de características robustas, com parede espessa. Em geral, foi possível chegar à formação das microcápsulas com uma morfologia semelhante às obtidas por Dhirendra et al.,(2008). 


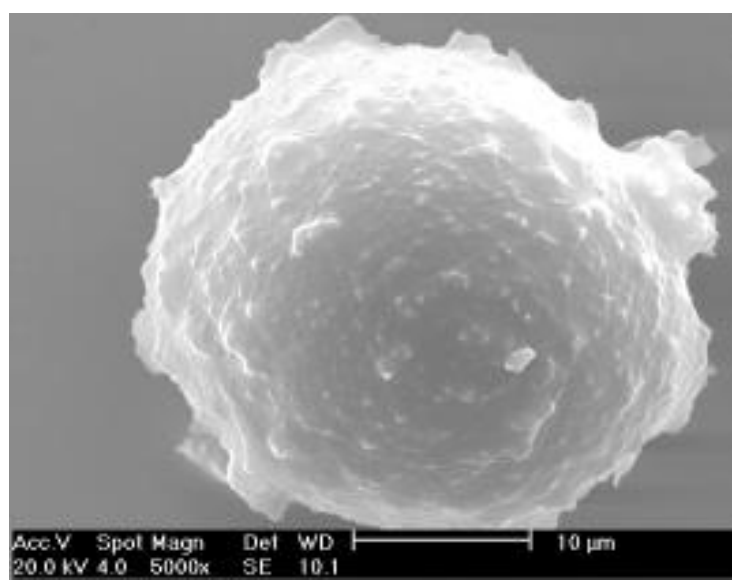

(a)

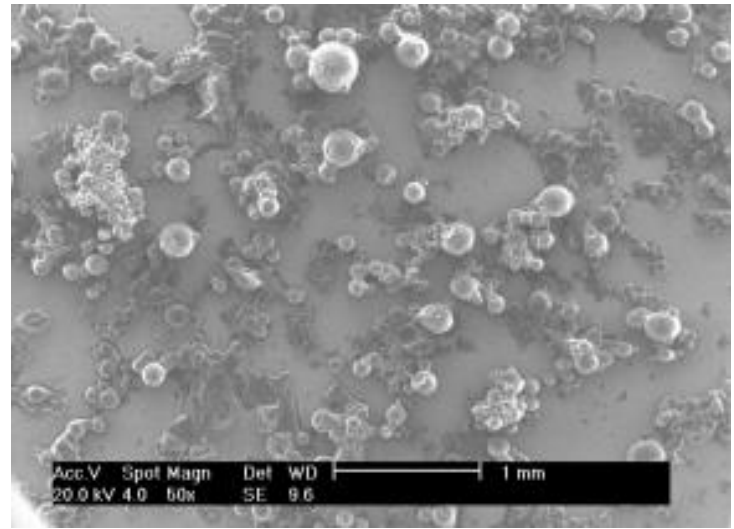

(c)

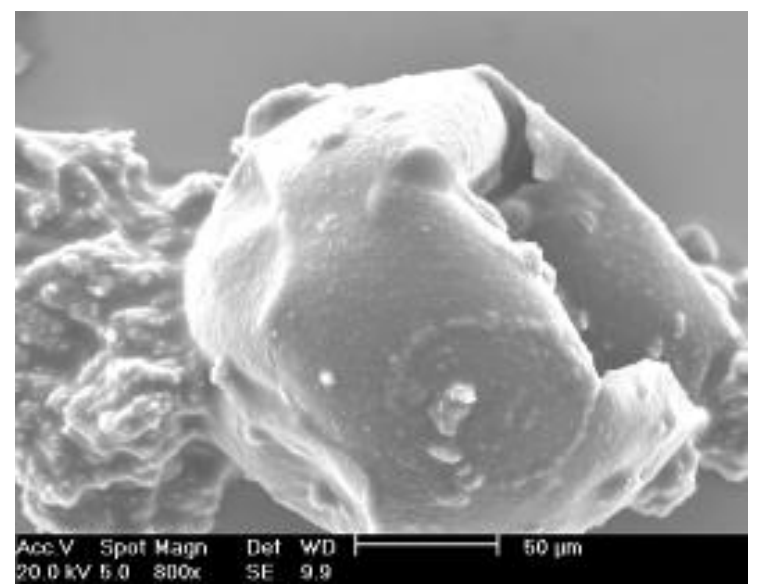

(b)

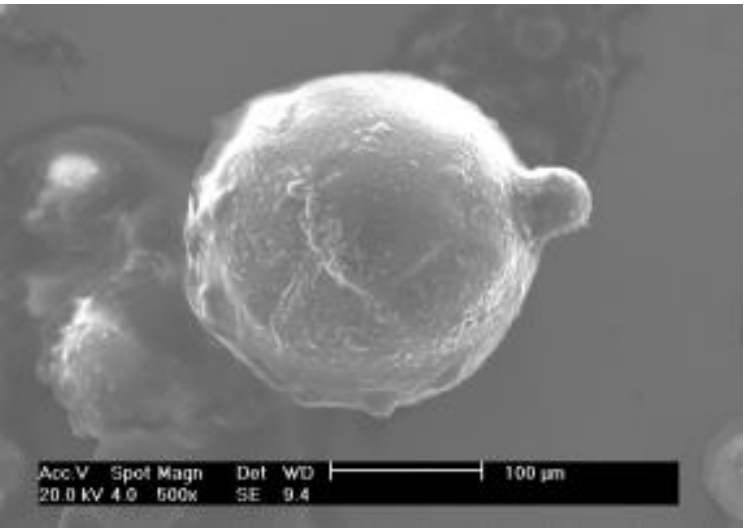

(d)

Figura 23- Micrografias obtidas por MEV com imagem de elétrons secundários das microcápsulas obtidas usando diferentes aumentos. (a) pequena microcápsula contendo óleo de linhaçã. (b) microcápsula quebrada. (c) grupo de microcápsulas e material restante da polimerização. (d) microcápsula contendo óleo de linhaça, com parede bem definida.

\subsection{DISCUSSÕES SOBRE O APRIMORAMENTO DA PREPARAÇÃO DO REVESTIMENTO TIPO “CLEAR”}

Durante a preparação do revestimento tipo "clear" seguindo a formulação dada por Dhirendra et al., se percebeu que a quantidade de diluentes para diluir a resina não era suficiente e, devido à alta viscosidade da resina obtida, sua aplicação sobre os corposde-prova resultou em um filme heterogêneo e muito espesso. Por isso se aumentou a 
porcentagem da mistura de solventes (xileno:butanol) da formulação, em relação à resina e se determinou que usando entre 20 e 25 partes de solvente em relação a 100 partes de resina, esta ficava com uma viscosidade menor, facilitando sua aplicação sobre os corpos-de-prova. Algumas outras mudanças foram necessárias para o aprimoramento da aplicação do "clear" e serão descritas nos itens seguintes.

\subsection{DISCUSSÕES SOBRE O APRIMORAMENTO DA PREPARAÇÃO DOS CORPOS-DE-PROVA REVESTIDOS}

Após vários testes preliminares de preparação dos corpos-de-prova se descobriram alguns pontos a serem considerados importantes como: a viscosidade do "clear" dada pela relação resina/solvente, a dispersão das microcápsulas e a técnica de aplicação do "clear". Como descrito no item anterior, a quantidade de solvente para diluir a resina não era suficiente, resultando em uma difícil aplicação sobre o metal, independentemente da técnica de aplicação usada. O segundo ponto é a adição das microcápsulas. Quando estas eram adicionadas na resina diluída, começaram a se aglomerar e quando aplicado o "clear", resultava um filme com microcápsulas aglomeradas (mal dispersas) como se vê na Figura 24. Assim, a espessura do filme aplicado por "dip coating" era menor que os aglomerados de microcápsulas e estas ficavam se sobressaindo do filme.

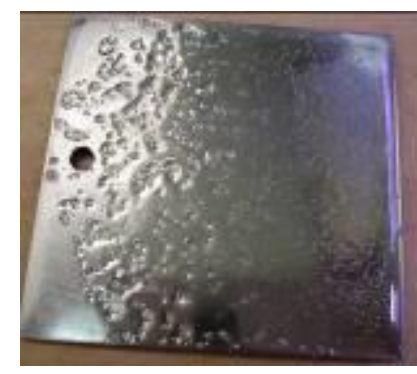

Figura 24-Aspecto de placa de aço carbono com uma demão de "clear" aplicado por "dip coating"aditivado com microcápsulas mal dispersas 


\subsubsection{Dispersão das microcápsulas nos diluentes do revestimento tipo "clear"}

Pelo resultado insatisfatório, se decidiu dispersar as microcápsulas em diluente para este ser logo em seguida adicionado à resina. Por isso foram feitos diferentes testes de dispersão de microcápsulas. Colocou-se em tubos de ensaio uma pequena porção do pó das microcápsulas com uma mistura de solventes (ver tabela 4), mas também foi estudado o efeito da presença de um surfactante, para melhorar a dispersão das microcápsulas na mistura de solventes, neste caso se usou o Silwet 7607. A figura 25 mostra, de forma qualitativa o resultado da dispersão. Esta dispersão foi feita com a ajuda de um banho de ultrassom. Os tubos de ensaio foram colocados no banho de ultrassom por 5 minutos. Se decidiu apresentar os resultados na tabela 4 de uma forma ilustrativa onde o traço negativo representa a não dispersão e o sinal de mais, positivo, representa uma boa dispersão. Foram utilizados cinco símbolos positivos ou negativos para classificar o resultado obtido.

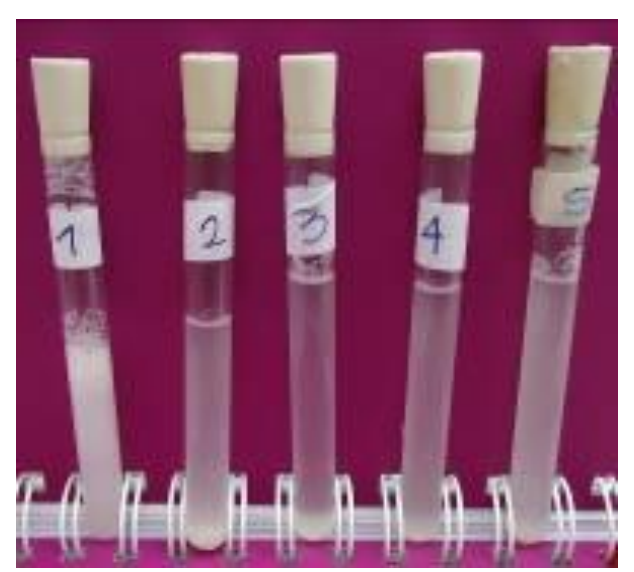

Figura 25-Imagem para a comparação da dispersão de microcápsulas em diferentes solventes com e sem o uso do emulsificante Silwet 7607 
Tabela 4-Dispersão de microcápsulas em diferentes solventes com e sem o uso do emulsificante Silwet 7607

\begin{tabular}{|c|c|c|c|}
\hline Tubo & Solventes & Silwet $7607(0,2 \mathrm{~mL})$ & Resultado \\
\hline 1 & Água & Sim & ---- \\
\hline 2 & Acetona + Butanol $(4: 1)$ & Não & +--- \\
\hline 3 & Xileno + butanol $(4: 1)$ & Não & +--- \\
\hline 4 & Xileno + Butanol $(4: 1)$ & Sim & ++++ \\
\hline 5 & Acetona + Butanol $(4: 1)$ & Sim & ++-- \\
\hline
\end{tabular}

A partir destes ensaios, o "clear" foi preparado usando a mistura de solventes xileno e butanol (4:1) com adição de $0,2 \mathrm{~mL}$ do Silwet 7607 no preparo de $5 \mathrm{~mL}$ de dispersão.

\subsubsection{Métodos de aplicação do revestimento tipo "clear"}

Depois o revestimento tipo "clear" foi aplicado nos corpos de prova com ajuda de um pincel, e estes levados à estufa a $50{ }^{\circ} \mathrm{C}$ para cura por 4 horas. $\mathrm{O}$ resultado de aplicação usando o pincel não foi satisfatório, pois este deixou as marcas das fibras fazendo com que a superfície não estivesse completamente lisa e homogênea. Assim, esta não homogeneidade da superfície levou a resultados de espectroscopia de impedância eletroquímica não reprodutíveis como será mostrado mais a diante.

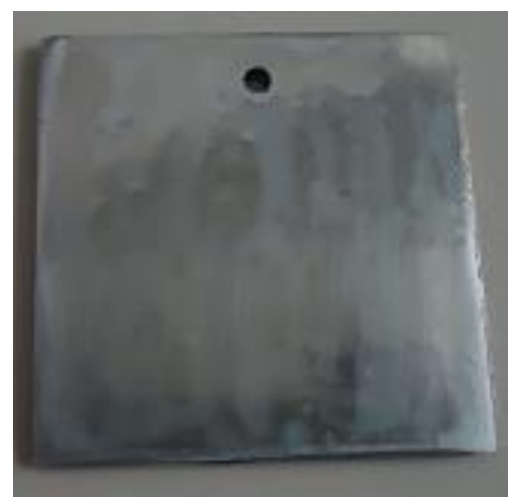

Figura 26- Resultado da aplicação do "clear" aditivado com as microcápsulas usando pincel 
A segunda técnica de aplicação do "clear" foi com a ajuda de um dip coater. Com esta técnica se conseguiu uma aplicação homogênea, mas assim que os corpos de prova passavam para a cura, a resina escoava pelo efeito da gravidade, o que, ao final, resultava como uma placa com revestimento de espessura não uniforme. Além disso, se percebeu a tendência das microcápsulas se aglomerarem enquanto a resina escorria fazendo as microcápsulas aparecerem, pois seu tamanho era maior que o da espessura da camada de "clear", pois se percebia a presença das microcápsulas ao longo de toda a superfície.

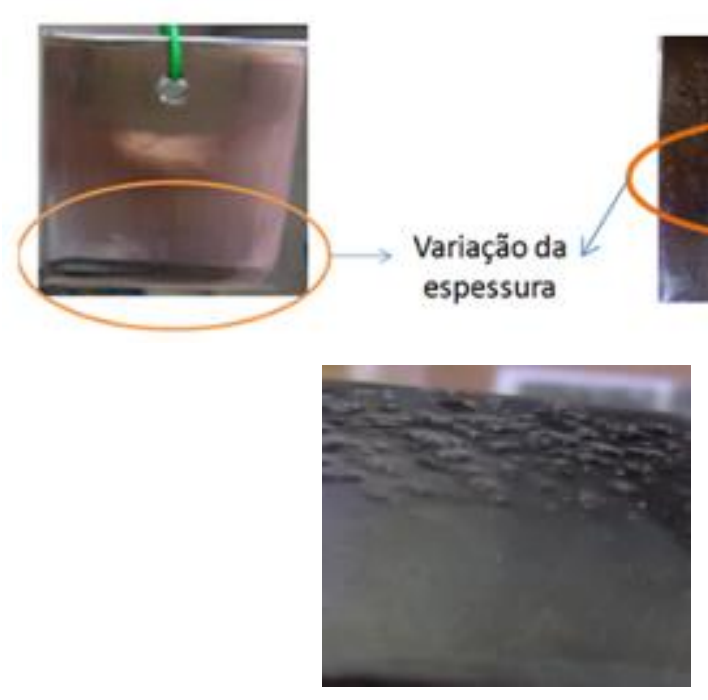

Figura 27- Resultado da aplicação do "clear" aditivado com microcápsulas usando o processo de "dip coating"

A terceira técnica utilizada para aplicação do revestimento tipo "clear" foi um extensor para controle da espessura da camada obtida. Nessa técnica se espalha uma quantidade de clear aditivado puxando um extensor que possui uma altura que limita a espessura da camada de tinta num determinado valor. No caso, se utilizou um extensor para produzir camada de revestimento úmido de 120 micras de espessura. 


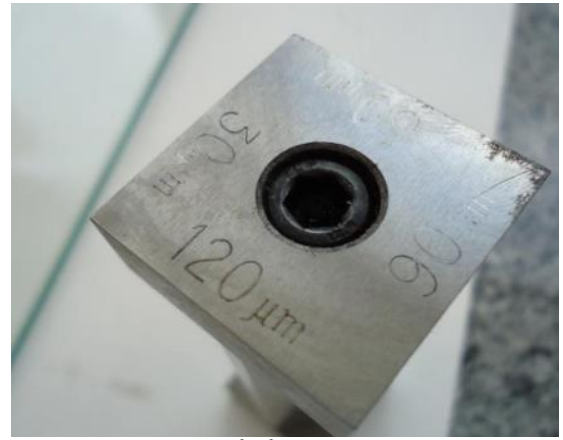

(a)

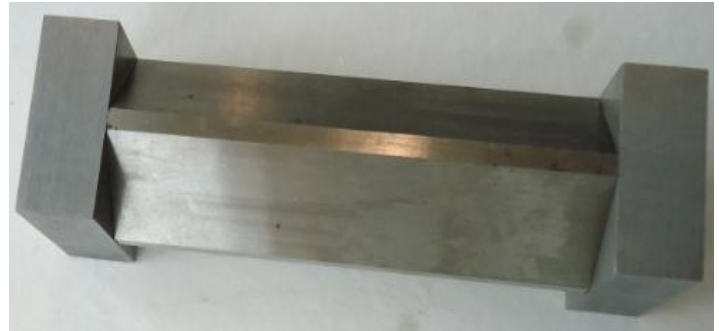

(b)

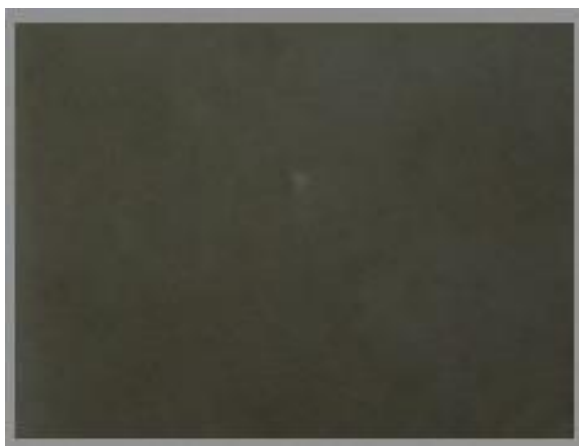

(c)

Figura 28- (a) e (b)Extensor de tinta para quatro espessuras. (c) Resultado da aplicação do "clear" usando extensor formador de uma película úmida com espessura de $120 \mu \mathrm{m}$.

\subsection{AVALIAÇÃO DO EFEITO "SELF-HEALING" NOS CORPOS DE PROVA REVESTIDOS}

As primeiras avaliações do efeito "self-healing" foram realizadas nas placas de aço revestidas onde a aplicação do "clear" aditivado com 10\% em massa de microcápsulas foi feita com pincel. O defeito mecânico foi feito com um estilete procurando sempre fazer o risco de um cm de comprimento.

Os resultados das medidas de impedância eletroquímica mostraram que não ocorre uma autorreparação do "clear", pois não houve aumento da resistência desse filme protetor como teoricamente deveria ocorrer. Há vários fatores que podem ter influenciado nos resultados de impedância, por exemplo, a falta de reprodutibilidade no 
tamanho e profundidade dos riscos nos diferentes corpos de prova. É possível que o risco de cada um dos corpos de prova não fossem iguais, em quanto a profundidade do defeito até alcançar o substrato. Então, mesmo que a teoria diga que para tempos maiores, o filme autorreparador deve representar valores de maior resistência à corrosão, um defeito de um corpo de prova sem aditivar que não chega ate o substrato poderá mostrar valores de resistência maiores do que o corpo de prova com defeito até substrato que, após de 48 horas de exposicão ao ar, formou um filme de autorreparação

Nessa ordem de idéias, não foi possível detectar um bom revestimento para nenhuma das amostras de aço revestido e sua autorreparação correspondente. Estes valores inesperados podem ser atribuídos a não uniformidade do filme (pois a aplicação com pincel não garante uma superfície homogênea), variação da espessura do filme e o tamanho e profundidade do defeito mecânico (risco feito com estilete).

\subsubsection{Influência da forma de execução do defeito no revestimento}

Depois dos primeiros resultados de impedância eletroquímica, se percebeu que dependendo da forma como o defeito é executado no revestimento tipo "clear" podem-se obter diferentes resultados, bons ou maus. Sem um controle do tamanho e reprodutibilidade na execução do defeito, os resultados levaram a dados não coerentes, na tentativa de mostrar o efeito self-healing.

Num primeiro instante se optou por usar um estilete, pois simularia um defeito mais real, mas os ensaios eletroquímicos são muito sensíveis quando se tem variações consideravelmente importantes como no caso da área exposta do metal revestido. Não se podia controlar a profundidade e a imprecisão do comprimento poderia influenciar nas medidas para verificar o efeito "self-healing". 
Alguns pesquisadores utilizaram ferramentas de maior precisão como o caso de um indentador (Feng et al., 2007; Blaiszik et al., 2010; Zheludkevich, et al., 2010). Seguindo essa idéia, se usou um indentador do tipo impacto com bala usado normalmente nas provas de resistência ao impacto. O resultado desta execução não foi satisfatório, pois o impacto foi muito forte, perfurando-se e deformando-se a placa de aço e assim mesmo se obteve um defeito não uniforme como é mostrado na figura 29. As trincas formadas após o impacto não eram uniformes, e os ensaios não eram reprodutíveis. Também se reduziu a força do impacto, mas neste caso, o defeito não era suficientemente profundo para atingir o metal.

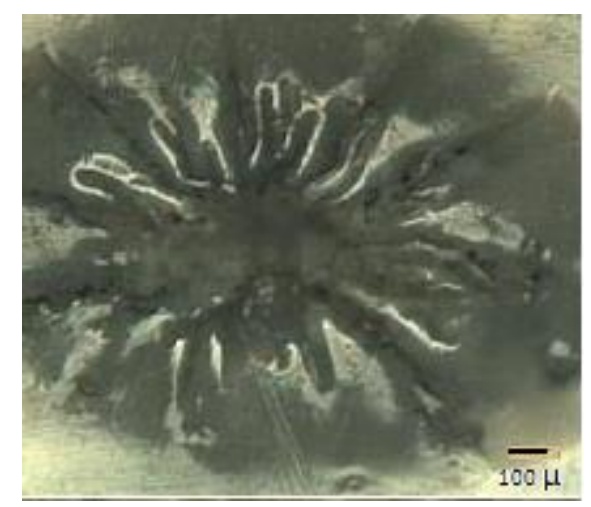

Figura 29- Aspecto do defeito realizado com indentador de prova de impacto

$\mathrm{Na}$ terceira tentativa de execução do defeito nos corpos-de-prova revestidos, se usou um indentador de um durômetro para plásticos, com o qual se podia ter um defeito reprodutível, pois a geometria do defeito é circular.

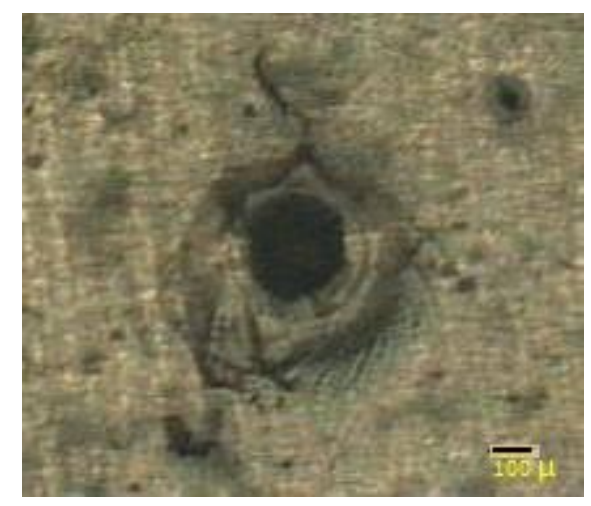

Figura 30- Aspecto do defeito executado com um durômetro para plásticos. 
Quando vistos ao microscópio, os defeitos, mesmo com área exposta controlada, apresentavam umas pequenas trincas ao redor do defeito. Por isso se passou a controlar a força manual aplicada com o durômetro. Fixou-se o valor de 50 N, pois com valores menores que este, não se conseguia atingir o metal, mas, com valores maiores, as trincas eram maiores. A intensidade da força na execução do defeito depende da espessura da camada de tinta. Quanto maior a espessura, há uma limitação na força aplicada. Para espessuras médias $(110 \mu \mathrm{m}-200 \mu \mathrm{m})$ a aplicação de $50 \mathrm{~N}$ é eficiente.

\subsubsection{Resultados de EIE para avaliar o efeito "Self-healing"}

Após o aprimoramento para efetuar o defeito sobre os corpos de prova revestidos com o clear contendo as microcápsulas, foram efetuadas as medidas de potencial de circuito aberto (Eoc) até a estabilização do mesmo em eletrólito: solução de $\mathrm{NaCl} 0,1 \mathrm{M}$. Encontrou-se que levava entre 100 e 120 minutos para o sistema não apresentar variações de potencial maiores que $10 \mathrm{mV}$ numa faixa de tempo de 10 minutos. As medidas de EIE foram realizadas sempre após 120 minutos de imersão do corpo de prova no eletrólito. Os tempos de exposição dos corpos de prova (0 horas, 24 horas e 48 horas) se referem ao tempo que o corpo de prova ficou exposto ao meio ambiente assim que o defeito foi produzido e antes de ser montado na célula eletroquímica para as medidas de impedância.

4.4.2.1 Resultados de EIE para corpo de prova revestido com revestimento clear aditivado com $5 \%$ em massa de microcápsulas

Usando $5 \%$ em massa de microcápsulas no revestimento "clear" a base epóxi, os resultados de EIE mostraram que quando ocorre o defeito, as microcápsulas estouram liberando o óleo de linhaça e o filme consegue se autorreparar. De acordo com os 
diagramas de Nyquist e de Bode, podemos dizer que esta porcentagem em massa consegue oferecer uma autorreparação significativa, porém se requer uma quantidade maior de microcápsulas para poder dizer que o processo de autorreparação é eficiente. De acordo com a literatura (Yang et al. 2012) uma quantidade ótima de microcápsulas pode ser 10\% em massa, que será discutida adiante, mas era importante para o estudo avaliar diferentes quantidades em massa de microcápsulas para encontrar o minimo necessario para conseuir autorreparação de filme. É importante ver, da mesma maneira, que realmente ocorre a formação do filme reparador e isso pode ser verificado pelos Diagrama de Nyquist na figura 31 (a) e de Bode na figura 31 (b). Analisando esses últimos diagramas, nas frequências intermediárias (análise feita à $50 \mathrm{~Hz}$ ), podemse ver a formação de duas constantes de tempo o que deve representar a regeneração do filme.

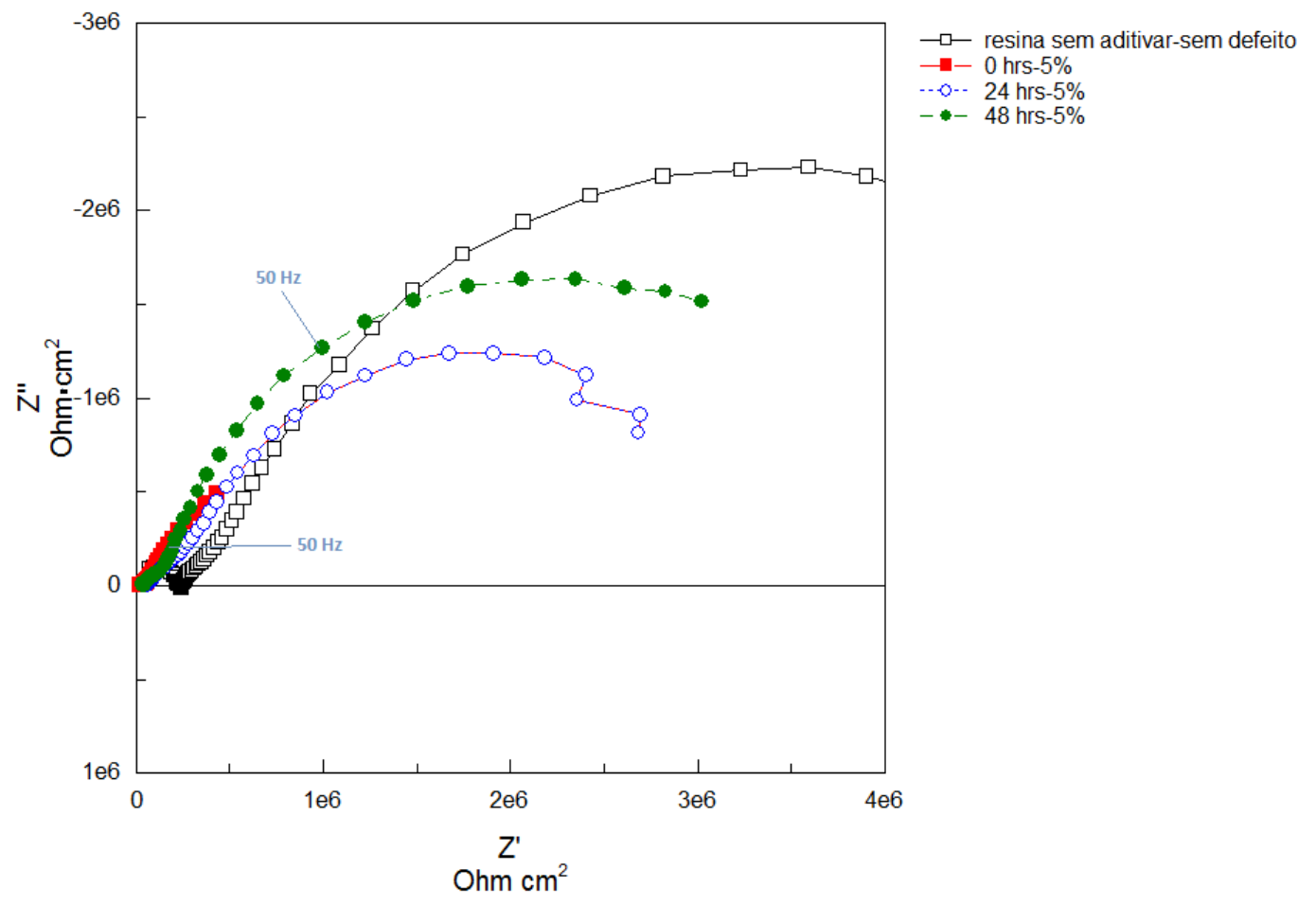

(a) 


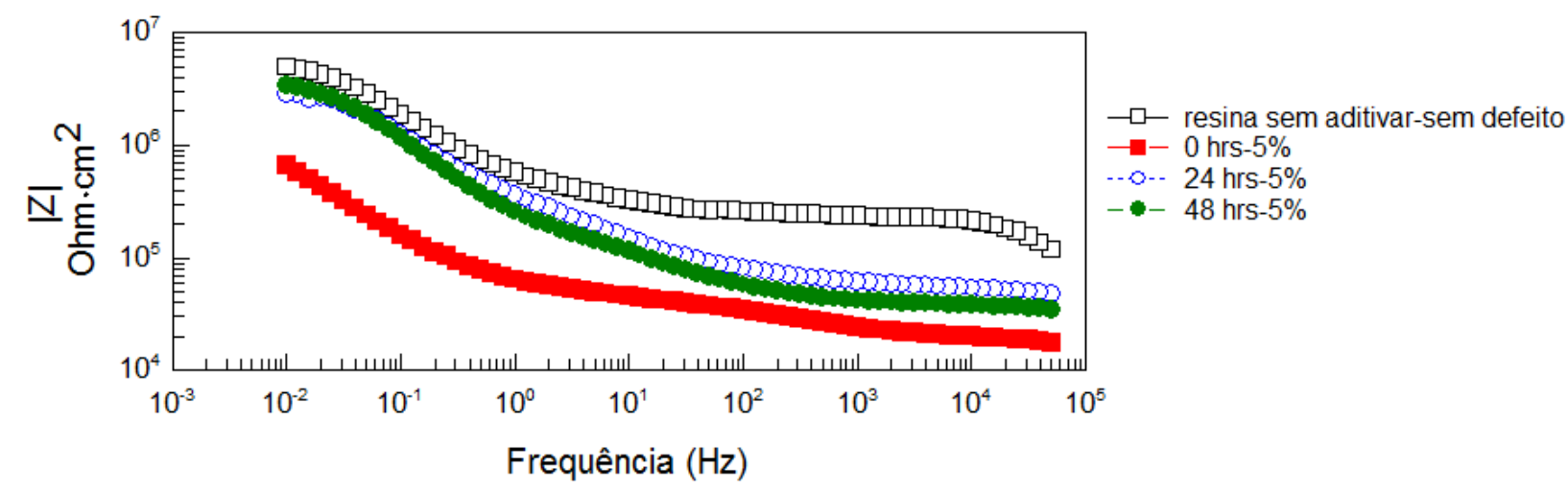

(b)

Figura 31- (a)Diagramas de Nyquist e (b) Diagrama de Bode para um sistema de aço carbono revestido com clear aditivado com $5 \%$ de microcápsulas, contendo óleo de linhaça para diferentes tempos após confecção do defeito, em $\mathrm{NaCl} 0,1 \mathrm{M}$.

4.4.2.2 Resultados de EIE para corpo de prova revestido com revestimento clear aditivado com $10 \%$ em massa de microcápsulas

Através da análise do diagrama de Bode (vide figura 32) é observada a atuação autorreparadora das microcápsulas ao liberar o óleo de linhaça, durante a execução do defeito, criando-se um filme pela polimerização do óleo de linhaça que atua como barreira contra a corrosão. Quando se analisa a impedância dos corpos de prova revestidos e com defeito, com o tempo após a confecção do defeito, os valores de módulo de impedância $|Z|$ apresentam um aumento até voltar perto da condição inicial, sem defeito. Quando o defeito tem 0 horas, ainda é muito recente a liberação do óleo de linhaça das microcápsulas e o filme de óleo de linhaça ainda não conseguiu se formar e secar. Apenas após um dia depois de se ter efetuado o defeito mecânico é quando se começa a verificar a formação de uma camada seca e estável de óleo de linhaça. Após 48 horas é possível determinar a formação de uma camada barreira que dificulta ainda mais a penetração do até a interfase metal/filme, onde ocorreria a corrosão. 


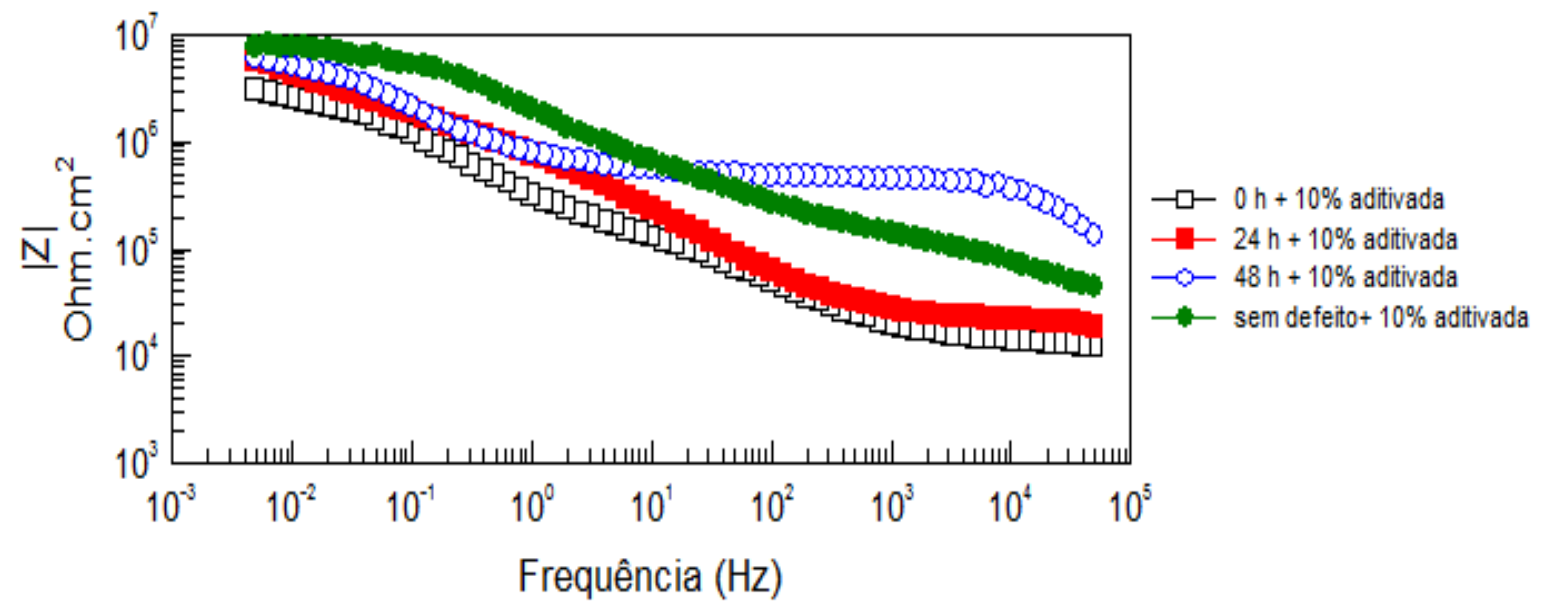

Figura 32- Diagramas de Bode para um sistema de aço revestido com revestimento tipo "clear" de epóxi aditivado com 10\% em massa de microcápsulas contendo óleo de linhaça após diferentes tempos depois de realizado o defeito, em $\mathrm{NaCl} 0,1 \mathrm{M}$.

Para ter uma comparação e determinar o desempenho autorreparador do óleo de linhaça, foi necessário realizar os mesmos ensaios de impedância para placas revestidas sem serem aditivadas. Para este caso, se encontrou que enquanto a resina está sem defeito, os valores de $|Z|$ se mantêm altos (ao redor de $10^{7}$ )) que são valores que representam um filme protetor. Já quando o defeito é realizado, e o ensaio é feito 24 horas após o defeito, podemos notar uma considerável diminuição no |Z| (caiu para a ordem de $10^{5} \mathrm{Ohm} . \mathrm{cm}^{2}$ ). Os diagramas de Bode de $\log \mid \mathrm{ZI} \times \log f$ permitem a comparação do que sucede quando o revestimento é aditivado e quando não é, após 24h decorridas da confecção do defeito (vide Figura 33). Desta forma, pode-se comprovar de uma forma qualitativa e quantitativa a autorreparação do revestimento em comparação com a referência negativa (revestimento com defeito e sem microcápsulas) e se verifica a melhora dos resultados para quando há aditivação tomando como referência positiva o revestimento aditivado com as microcápsulas e sem defeito. Para o revestimento aditivado e com o defeito, a resposta é muito próxima da resposta da referência positiva. 


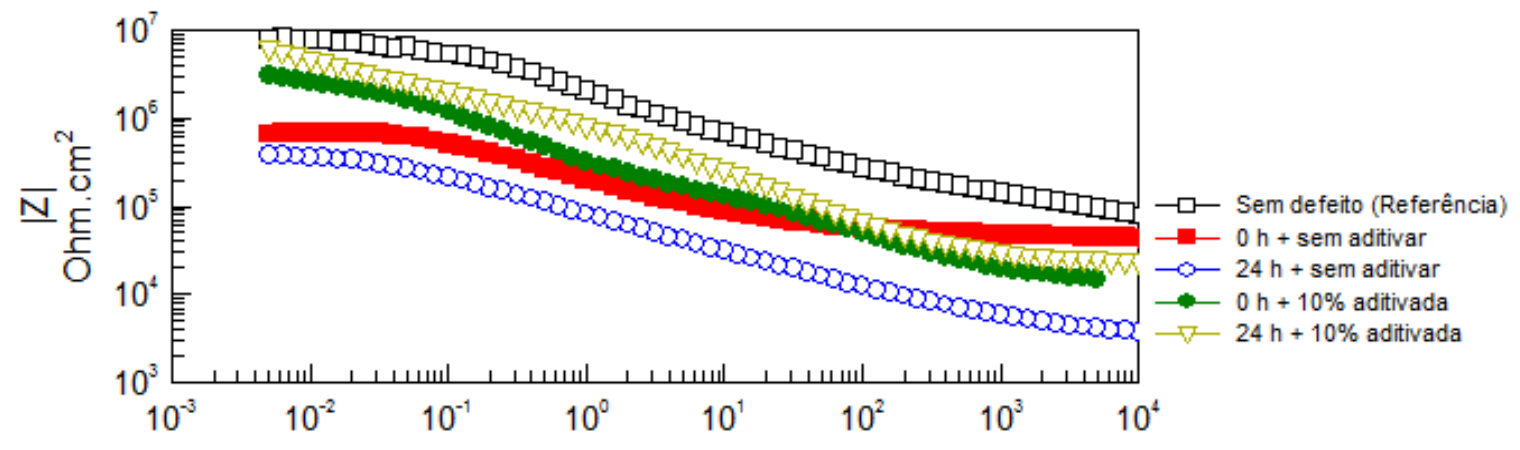

Frequência $(\mathrm{Hz})$

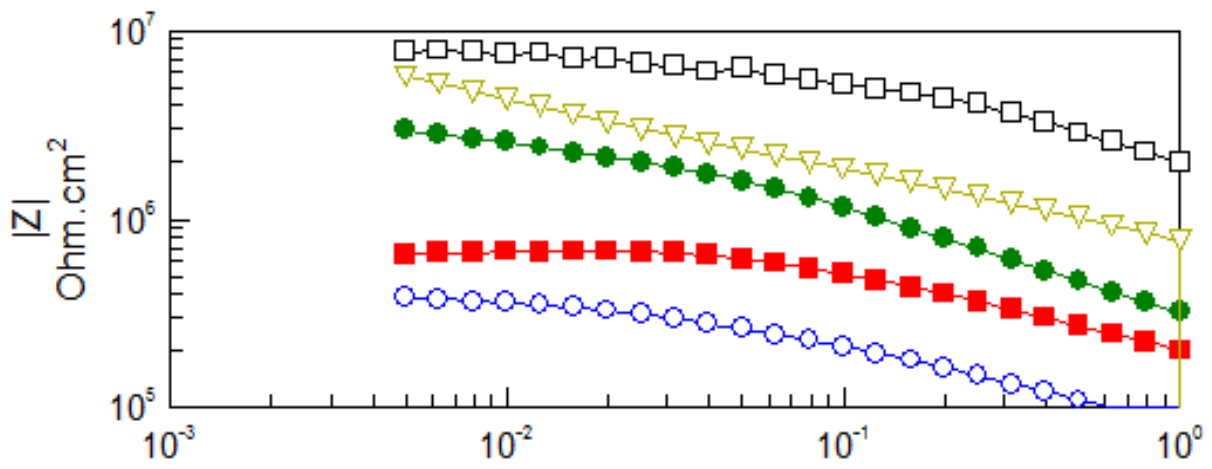

Frequência $(\mathrm{Hz})$

Figura 33- Diagramas de Bode de log $|Z|$ x log f para um sistema de aço carbono revestido com "clear" aditivado ou não com $10 \%$ de microcápsulas, contendo óleo de linhaça após $24 \mathrm{~h}$ da confecção do defeito, e imerso em $\mathrm{NaCl} 0,1 \mathrm{M}$

A figura 34 apresenta a relação inversa que existe entre a evolução do módulo de impedância a $50 \mathrm{mHz}$ do aço carbono revestido com "clear" quando aditivado e sem aditivar com o tempo de exposição do defeito ao ar.

Quando se analisa a tendência da curva para a condição "aditivada 10\%" entre 0 horas a 24 horas, existe uma inclinação positiva mais acentuada do que a curva entre 24 horas e 48 horas, o que indica que nas primeiras 24 horas (que o óleo de linhaça foi liberado das cápsulas a pelo defeito e exposto ao ar do ambiente) é onde estão ocorrendo as reações dos ácidos graxos (ácido oleico linoléico e linolênico) para a formação dos radicais que serão responsáveis pelo entrecruzamento das cadeias, enquanto que na segunda parte a inclinação mesmo continuando positiva (continua autorreparando o filme pois esta aumentando o valor do módulo de impedância), é 
menos acentuada,sugerindo que esses ácidos graxos já reagiram e já existe um filme muito mais resistente e insolúvel tal como foi sugerido por Chiantore e Lazzari (1999)

Por outro lado, colocando um gráfico o valor do módulo de impedância a uma frequência de $50 \mathrm{mHz}$, contra o tempo decorrido após o defeito ser realizado, a tendência da curva obtida para o "clear" sem aditivar está mostrando que a diminuição do módulo de impedância é muito mais rápida com o tempo pois se está desencadeando uma reação rápida de corrosão do substrato que ficou exposto ao ar sem ser protegido que não pode se reparar pela inexistência das microcápsulas contendo óleo de linhaça..

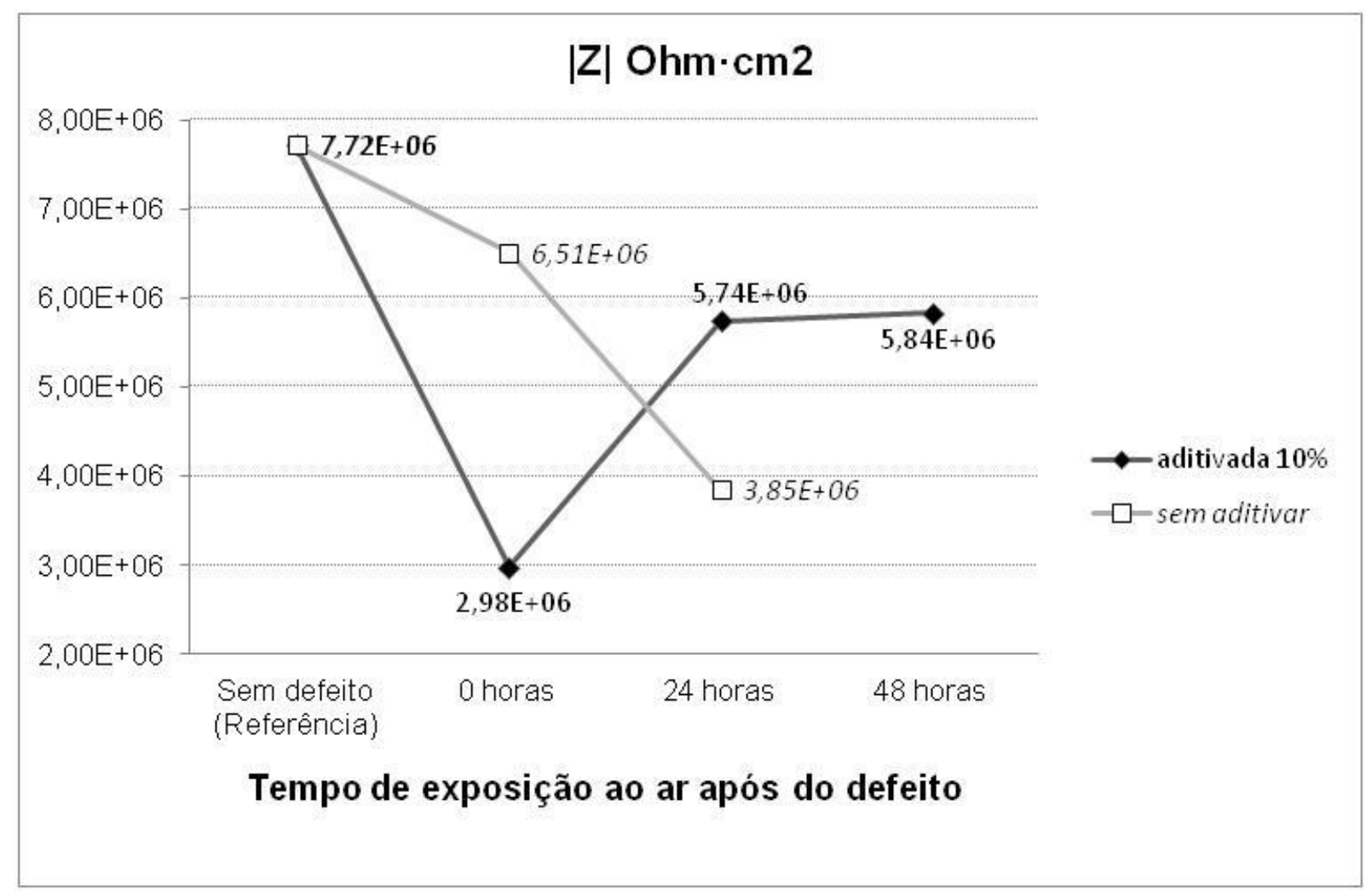

Figura 34- Comportamento do módulo de impedância com o tempo para corpos de prova de aço carbono revestidos com resina epóxi aditivada com microcápsulas contendo óleo de linhaça como agente autorreparador e resina epóxi sem aditivar imersos em solução de $\mathrm{NaCl} 0,1 \mathrm{M}$ apos do defeito no revestimento e expostos ao ar por 0, 24 e 48 horas. 


\subsection{AVALIAÇÃO DO EFEITO DE "SELF HEALING" COM O ENSAIO ACELERADO DE CORROSÃO EM CÂMARA DE NÉVOA SALINA}

Os corpos de prova que foram expostos na câmara de névoa salina apresentaram um comportamento que está coerente com o obtido pela técnica de impedância eletroquímica. Cada uma das chapas que era revestida com a resina epóxi, aditivada ou não com microcápsulas, teve o defeito executado no mesmo dia, para garantir condições similares para poder comparar os resultados obtidos.

As primeiras chapas de aço revestidas que foram introduzidas na câmara de névoa salina representaram 0 horas de formação do filme, pois foram colocadas na câmara logo após a confecção do defeito e, onde se esperava que o grau de ataque da corrosão fosse o maior de todas as condições estudadas. Neste caso, tanto a chapa com resina aditivada como a chapa com resina não aditivada apresentaram um importante ataque corrosivo. Após 24 horas de exposição do defeito ao ar, foram introduzidas as chapas de 24 horas, tempo durante o qual a autorreparação do filme deve ter ocorrido. Assim, para tempos crescentes de exposição do defeito ao ar, as chapas revestidas foram colocadas na câmara, permitindo que quanto mais tempo passasse, a autorreparação do filme fosse ocorrendo de forma mais efetiva, permitindo não somente a formação do filme de óleo de linhaça, como também a cura do mesmo. Cada grupo de três chapas representando uma dada condição era empregado, garantindo a validação estatística dos resultados pelo uso de corpos de prova em triplicata. Quando cada grupo de chapas atingia um dia completo de exposição à névoa salina, era retirado para ser fotografado e retornava à câmara até que se completassem os 7 dias de exposição.

A figura 35 mostra a sequência das chapas ao longo do tempo, comprovando que com o passar do tempo, de 24 em 24 horas, consegue-se verificar a autorreparação do revestimento pela formação do filme de óleo de linhaça polimerizado na área danificada, diminuindo ou eliminando a presença de produtos de corrosão na região do defeito provocado. 


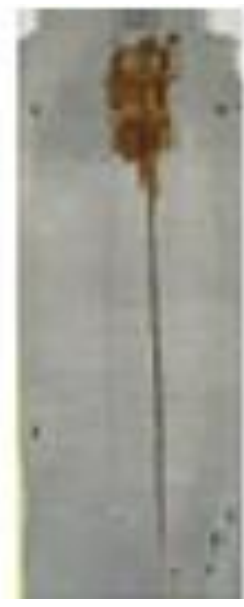

(a)

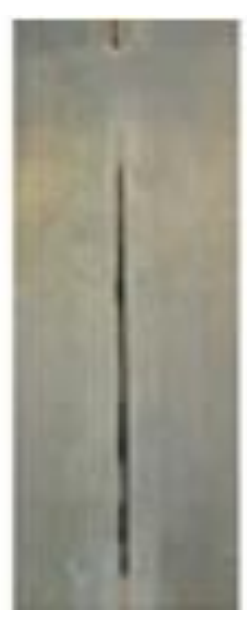

(b)

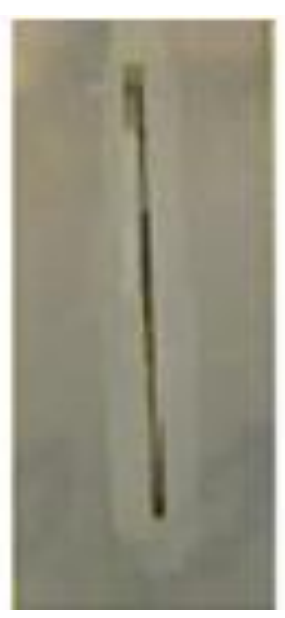

(c)

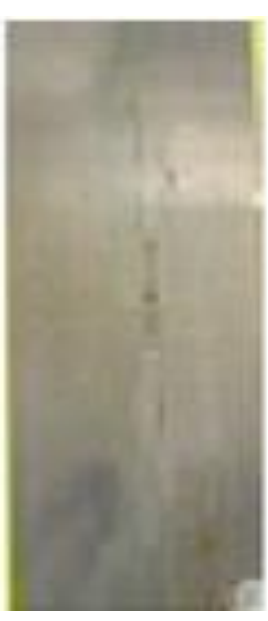

(d)

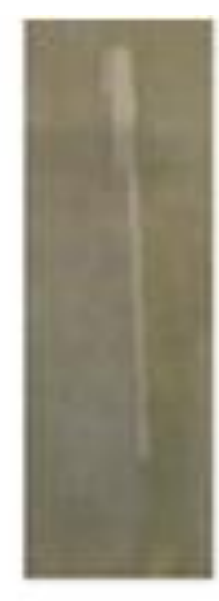

(e)

Figura 35- Aparência dos painéis revestidos com resina epóxi (a) referência negativa - não aditivada- e painéis revestidos com resina aditivada com 10\% em massa de microcápsulas contendo óleo de linhaça, com um tempo de confecção do defeito de (b) 0 horas, (c) 24 horas, (d) 48 horas, (e) 72 horas. Tempo de permanência dentro da câmara de névoa salina: um dia.

Também foi avaliada a estabilidade do filme de óleo de linhaça polimerizado com a exposição contínua dos corpos de prova à névoa salina durante uma semana. Para esta avaliação foram colocadas as chapas revestidas com resina clear aditivada ou não com as microcápsulas, com defeito, sendo que algumas foram expostas na câmara após 0h ou 24h da confecção do defeito. A figura 36 mostra as fotografias das chapas após transcorrida uma semana de exposição na câmara de névoa salina. 


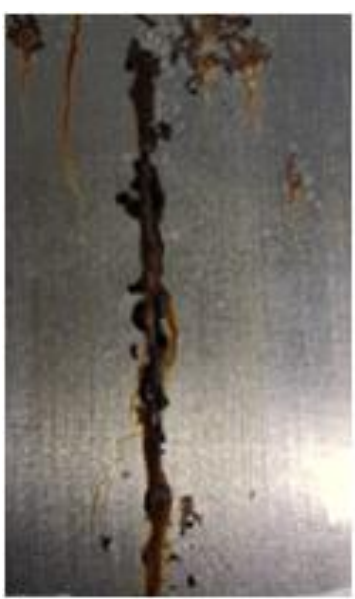

a

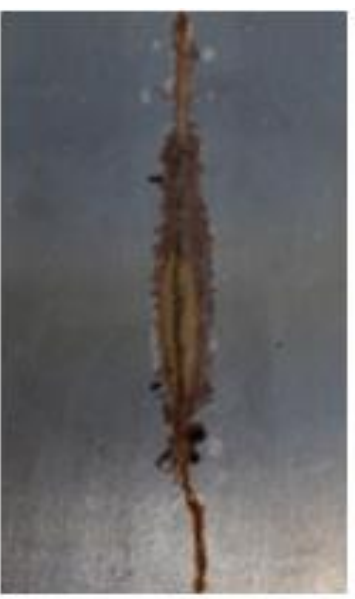

b

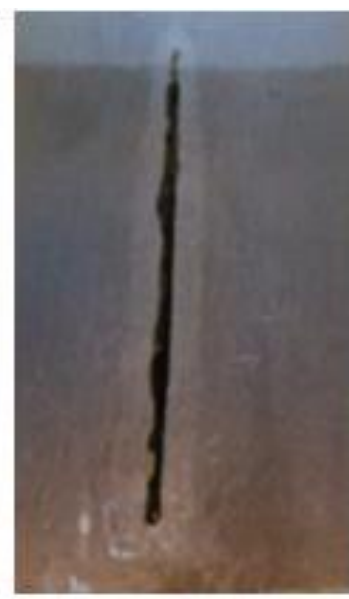

C

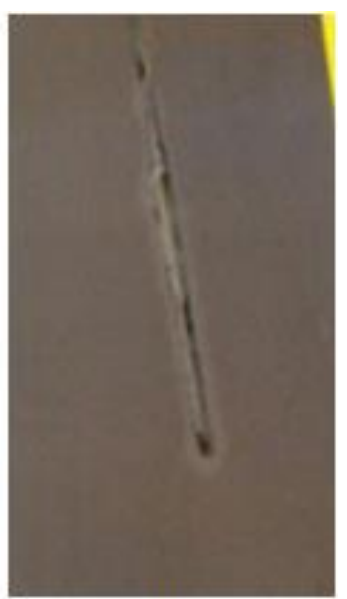

d

Figura 36- Aparência dos painéis revestidos após uma semana de exposição à névoa salina (a) com resina epóxi sem aditivar e colocada dentro da câmara de névoa salina após 0 horas da confecção do defeito, (b) com resina epóxi sem aditivar e 24 horas da confecção do defeito, (c) com resina epóxi aditivada com 10\% em massa de microcápsulas e 0 horas da confecção do defeito, (d) com resina epóxi aditivada com 10\% em massa de microcápsulas e 24 horas da confecção do defeito.

A influência da presença das microcápsulas na autorreparação do filme é evidente. A exposição do defeito por $24 \mathrm{~h}$ ao ar antes de adentrar a câmara de névoa salina, também mostrou formar um filme polimerizado e que confere proteção à zona do defeito, pois nessas chapas (Figura 36-d) praticamente não é observada a presença de produtos de corrosão na região do corte. 


\section{CONCLUSÕES}

A formação das microcápsulas por polimerização de formol-uréia em uma emulsão de óleo de linhaça em água começa a ser efetiva a partir das 3 horas de emulsão quando se segue a metodologia dada por Brown e White, porém para garantir uma maior estabilidade das microcápsulas e por conseguinte maior quantidade das mesmas é importante a adição de um surfactante como o Renex-95.

Com MEV se identificou a formação de microcápsulas robustas e de diâmetro medio

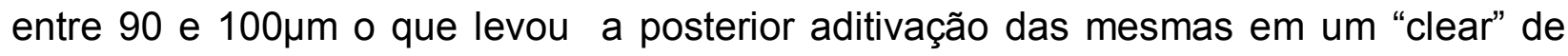
maior espessura $(120 \mu \mathrm{m})$. Além disso, pode-se ver que paara melhorar o rendimento das microcápsulas, o processo de limpeza das mesmas deve ser aprimorado com técnicas mais avançadas, pois ainda encontram-se restos não desejados ao redor delas, o que pode interferir no desempenho das mesmas.

O defeito deve ser controlado e o uso de um indentador de durômetro para plásticos mostrou ser uma forma eficiente e reprodutível de provocar o defeito.

As técnicas de aplicação de revestimentos devem garantir uma superficie homogênea, isto foi conseguido unicamente pela técnica de aplicação com um extensor, o que garantiu um filme uniforme de espessura homogenea de $120 \mu \mathrm{m}$ cobrindo totalmente as microcápsulas que têm em média $90 \mu \mathrm{m}$ de diâmetro.

A técnica de EIE permitiu que se verificasse o efeito de autorreparação proporcionado pelas cápsulas contendo óleo de linhaça quando aditivando um revestimento tipo clear à base de resina epóxi.

O desempenho do óleo de linhaça como o agente de autorreparação foi bom pois se conseguiu a autorreparação do filme de resina epóxi. A análise dos dados de espectroscopia de impedância eletroquímica mostrou que a utilização de $5 \%$ em massa 
de microcápsulas aditivadas na resina epóxi levou a resultados satisfatórios de autorreparação, embora com $10 \%$ em massa se obtiveram dados muito mais significativos, ao conseguir que o filme se autorreparasse oferecendo proteção próxima daquela do filme sem defeito.

Nos testes de câmara de névoa salina foram comprovados os dados obtidos pela espectroscopía de impedância eletroquímica, os quais demonstraram que de fato houve a liberacão do óleo de linhaça e sua polimerização com o oxigênio do ar, permitindo que o filme seja autorreparado e possa oferecer proteção contra a corrosão do substrato. 


\section{SUGESTÕES PARA TRABALHOS FUTUROS}

Os resultados obtidos neste trabalho indicam que alguns estudos adicionais poderiam ser realizados para melhorar a compreensão dos processos ocorridos, tais como:

1) Estudar o emprego de outros surfactantes para serem utilizados na formação da emulsão do meio aquoso e o óleo de linhaça polimerizado.

2) Estudar o reforço das paredes das microcápsulas usando a melamina como agente de reticulação, impedindo que o óleo de linhaça difunda através das paredes das microcápsulas.

3) Aplicar as microcápsulas em tintas de uso corrente, na prática, para proteção de tubulações e tanques. 


\section{REFERÊNCIAS}

BASTOS, A C.; ZHELUDKEVICH, M. L.; FERREIRA, M. G. S. Concerning the Efficiency of Corrosion Inhibitors as Given by SVET. Portugaliae Electrochimica Acta, v. 26, n. 1, p. 47-54, 2007.

BEIERMANN, B. A; KELLER, M. W.; SOTTOS, N. R. Self-healing flexible laminates for resealing of puncture damage. Smart Materials and Structures, v. 18, n. 8, p. 085001, 1 ago. 2009.

BHATHENA, J. et al. Preparation and in vitro analysis of microencapsulated live Lactobacillus fermentum 11976 for augmentation of feruloyl esterase in the gastrointestinal tract. Biotechnology and Applied Biochemistry, v. 50, p. 1-9, May 2008. ISSN 0885-4513. Disponível em: <<Go to ISI>://WOS:000255677400001 >.

BLAISZIK, B. J. et al. Microcapsules filled with reactive solutions for self-healing materials. Polymer, v. 50, n. 4, p. 990-997, 9 fev. 2009.

BLAISZIK, B. J. et al. Self-Healing Polymers and Composites. Annual Review of Materials Research, v. 40, n. 1, p. 179-211, jun. 2010.

BROWN, E. N. et al. In situ poly(urea-formaldehyde) microencapsulation of dicyclopentadiene. Journal of Microencapsulation, v. 20, n. 6, p. 719-730, Nov-Dec 2003. ISSN 0265-2048. Disponível em: <<Go to ISI>://WOS:000186296700002 >.

CABRERA-SIERRA, R.; MARÍN-CRUZ, J.; GONZÁLEZ, I. La utilización de la espectroscopia de impedancia electroquímica ( EIS ) para identificar diferentes estados superficiales en el proceso de corrosión del acero al carbono en medios amargos. v. 1, n. 1, p. 32-41, 2007.

COSCO, S. et al. Properties of poly(urea-formaldheyde) microcapsules containing an epoxy resin. Journal of Applied Polymer Science, v. 105, n. 3, p. 1400-1411, Aug 5 2007. ISSN 0021-8995. Disponível em: <<Go to ISI>:/WOS:000247576000047 >.

DI SARLI, A.R., SANTÁGATA, D.I. Evaluation of the surface treatment effect on the corrosion performance of paint coated carbon steel. Progress in Organic Coatings, $v$. 33, n. 1, p. 44-54, jan. 1998. 
DLUGOGORSKI, B. Z.; KENNEDY, E. M.; MACKIE, J. C. Oxidation reactions and spontaneous ignition of linseed oil. Proceedings of the Combustion Institute, v. 33, n. 2, p. 2625-2632, 2011. Elsevier Inc. Disponível em: $<$ http://linkinghub.elsevier.com/retrieve/pii/S1540748910001677>. Acesso em: 26/8/2012.

DUBEY, R.; SHAMI, T. C.; RAO, K. U. B. Microencapsulation Technology and Applications. Defence Science Journal, v. 59, n. 1, p. 82-95, Jan 2009. ISSN 0011 748X. Disponível em: <<Go to ISI>://WOS:000263594800012 >.

FAZENDA, J. M. R. Tintas e Vernizes. Abrafati v. 2. ISBN: 8521203748. 1993.

FRANKEL, G. S.; McCREERY, R. L., Inhibition of Al Alloy Corrosion by Chromates, The Electrochemical Society Interface, p. 34-38, Winter 2001.

FORSSELL, P.; PARTANEN, R.; POUTANEN, K. Microencapsulation - better performance of food ingredients. FOOD SCIENCE AND TECHNOLOGY -LONDON-, v. 20, n. 3, p. 18 - 20, 11 Sep 2006 2006. ISSN 1475-3324.

GHANBARZADEH, A.; AKBARINEZHAD, E. Sulfonation of base oils as corrosion inhibitor for temporary protection of steel in atmospheric environment. Progress in Organic Coatings, v. 56, n. 1, p. 39-45, maio. 2006.

GÓMEZ DE LEÓN, F.C. Manual básico de corrosión para ingenieros Editum. ediciones de la universidad de Murcia, p.170, Nov 2004

GOSH, S. K. Functional coatings by polymer microencapsulation. WILEY-VCH Verlag GmbH \& Co. KGaA, Weinheim. 2006

GONZÁLEZ-GARCÍA, Y.; GONZÁLEZ, S.; SOUTO, R. M. Electrochemical and structural properties of a polyurethane coating on steel substrates for corrosion protection. Corrosion Science, v. 49, n. 9, p. 3514-3526, set. 2007.

HAN, L.; SONG, S. A measurement system based on electrochemical frequency modulation technique for monitoring the early corrosion of mild steel in seawater. Corrosion Science, v. 50, n. 6, p. 1551-1557, jun. 2008. 
JIN, H. et al. Fracture and fatigue response of a self-healing epoxy adhesive. Polymer, v. 52, n. 7, p. 1628-1634, mar. 2011.

LAZZARI, M.; CHIANTORE, O. Drying and oxidative degradation of linseed oil. Polymer Degradation and Stability, v. 65, p. 303-313, Feb.1999.

LEE, J. et al. Micromechanical behavior of self-healing epoxy and hardener-loaded microcapsules by nanoindentation. Materials Letters, v. 76, p. 62-65, jun. 2012.

KARTSONAKIS, I. A., et al. Incorporation of ceramic nanocontainers into epoxy coatings for the corrosion protection of hot dip galvanized steel. Corrosion Science, v. 57, p. 3041, Apr. 2012.

KOLEK, Z. Characterization of water penetration inside organic coatings by capacitance measurements. Progress in Organic Coatings, v. 30, n. 4, p. 287-292, Apr 1997. ISSN 0300-9440. Disponível em: <<Go to ISI>:/WOS:A1997XM97800012 >.

KUMAR, A.; STEPHENSON, L. D.; MURRAY, J. N. Self-healing coatings for steel. Progress in Organic Coatings, v. 55, n. 3, p. 244-253, Mar 1 2006. ISSN 0300-9440. Disponível em: <<Go to ISI>://WOS:000236079300005 >.

KUMAR, D SURYANARAYANA, C.; RAO, K. C.;. Preparation and characterization of microcapsules containing linseed oil and its use in self-healing coatings. Progress in Organic Coatings, v. 63, n. 1, p. 72-78, jul. 2008.

MEHTA, N. K.; BOGERE, M. N. Environmental studies of smart/self-healing coating system for steel. Progress in Organic Coatings, v. 64, n. 4, p. 419-428, mar. 2009.

MONTEMOR, M. F.; PINTO, R.; FERREIRA, M. G. S. Chemical composition and corrosion protection of silane films modified with $\mathrm{CeO} 2$ nanoparticles. Electrochimica Acta, v. 54, n. 22, p. 5179-5189, set. 2009.

NECHAEVA, E. A. et al. Approaches to development of microencapsulated form of the live measles vaccine. Bioartificial Organs lii: Tissue Sourcing, Immunoisolation, and Clinical Trials, v. 944, p. 180-186, 2001 2001. ISSN 0077-8923. Disponível em: < $<$ Go to ISI $>$ ://WOS:000173774500014 > 
NELSON, G. Application of microencapsulation in textiles. International Journal of Pharmaceutics, v. 242, n. 1-2, p. 55-62, Aug 21 2002. ISSN 0378-5173. Disponível em: $<<$ Go to ISI $>$ ://WOS:000179539900007 >.

NESTEROVA, T.; DAM-JOHANSEN, K.; KIIL, S. Synthesis of durable microcapsules for self-healing anticorrosive coatings: A comparison of selected methods. Progress in Organic Coatings, v. 70, n. 4, p. 342-352, Apr 2011. ISSN 0300-9440. Disponível em: $<<$ Go to ISI $>$ :/WOS:000289601500027 >.

OLIVIER, M.-G.; HANG, T. T. X.; TRUC, T. A. et al. Corrosion protection mechanisms of carbon steel by an epoxy resin containing indole-3 butyric acid modified clay. Progress in Organic Coatings, v. 69, n. 4, p. 410-416, 2010. Elsevier B.V. Disponível em: $<$ http://linkinghub.elsevier.com/retrieve/pii/S0300944010002286>. Acesso em: 26/8/2012.

PERES, R. O., Propriedades anticorrosivas de camadas de conversão à base de taninos como pré-tratamento para o aço carbono 1020. 2010. 105p. Dissertação (Mestrado)- Universidade Federal do Rio Grande do Sul, 2010.

RULE, J. D.; SOTTOS, N. R.; WHITE, S. R. Effect of microcapsule size on the performance of self-healing polymers. Polymer, v. 48, n. 12, p. 3520-3529, Jun 42007. ISSN 0032-3861. Disponível em: <<Go to ISI >:/WOS:000247450100020 >

SAMADZADEH, M. et al. Tung oil: An autonomous repairing agent for self-healing epoxy coatings. Progress in Organic Coatings, v. 70, n. 4, p. 383-387, Apr 2011. ISSN 0300-9440. Disponível em: <<Go to ISI>://WOS:000289601500033 >.

SHCHUKIN, D. G.; MOEHWALD, H. Self-repairing coatings containing active nanoreservoirs. Small, v. 3, n. 6, p. 926-943, Jun 2007. ISSN 1613-6810. Disponível em: $<<$ Go to ISI $>$ ://WOS:000247148200002 >.

SOUTO, R. M. et al. Self-healing processes in coil-coated cladding studied by the scanning vibrating electrode. Electrochimica Acta, v. 55, n. 15, p. 4551-4557, jun. 2010. 
STOYE, D.; FREITAG, W. Paints, coatings and solvents. 2nd, completely rev. Weinheim ; Chichester: Wiley-VCH, 1998. xvii,414p ISBN 3-527-28863-5

SUKHORUKOV, G.; FERY, A.; MOHWALD, H. Intelligent micro- and nanocapsules. Progress in Polymer Science, v. 30, n. 8-9, p. 885-897, Aug-Sep 2005. ISSN 00796700. Disponível em: <<Go to ISI>://WOS:000232170700007 >

TAO, C.; CHEN, D.; ZHANG, J. The fabrication of hollow BSA micro/nanocapsules. Journal of Nanoscience and Nanotechnology, v. 7, n. 8, p. 2930-2932, Aug 2007. ISSN 1533-4880. Disponível em: <<Go to ISI>:/MOS:000247884000051 >.

TING, Z. et al. Optimal Preparation and Characterization of Poly(urea-formaldehyde) Microcapsules. Journal of Applied Polymer Science, v. 115, n. 4, p. 2162-2169, Feb 15 2010. ISSN 0021-8995. Disponível em: < <Go to ISI>://WOS:000272893400030 >.

THIES, C. Microcapsules For Cosmetic Applications. Abstracts of Papers of the American Chemical Society, v. 200, p. 54-PMSE, Aug 26 1990. ISSN 0065-7727. Disponível em: <<Go to ISI>://WOS:A1990DU04301276

VAN WESTING, E. P. M.; FERRARI, G. M.; GEENEN, F. M.; DE WIT, J. H. W. In situ determination of the loss of adhesion of barrier epoxy coatings using electrochemical impedance spectroscopy. Progress in Organic Coatings, v. 23, n. 1, p. 89-103, 1993. Disponível em: <http://linkinghub.elsevier.com/retrieve/pii/003306559380006V>.

WHITE, S. R.; CHO, S. H.; BRAUN, P. V. Self-Healing Polymer Coatings. Advanced Materials, v. 21, n. 6, p. 645-+, Feb 9 2009. ISSN 0935-9648. Disponível em: < <Go to ISI ://WOS:000263492000002 >.

WOLYNEC, S. Técnicas eletroquímicas em corrosão. São Paulo: EDUSP, 2003. ISBN 85314074949788531407499.

YU, G. et al. Preparation of microcapsule by using chitosan for carbonless paper. Chung-kuo Tsao Chih/China Pulp and Paper, v. 21, n. 1, p. 19 - 22, 2002.

YUAN, Y. C. Self healing in polymers and polymer composites. Concepts, realization and outlook: A review. EXPRESS Polymer Letters, v. 2, n. 4, p. 238-250, 31 mar. 2008. 
ZHAO, Y. et al. Self-healing coatings containing microcapsule. Applied Surface Science, v. 258, n. 6, p. 1915-1918, Jan. 2012.

ZHELUDKEVICH, M. L. et al. Active protection coatings with layered double hydroxide nanocontainers of corrosion inhibitor. Corrosion Science, v. 52, n. 2, p. 602-611, fev. 2010.

ZHELUDKEVICH, M. L. et al. On the application of electrochemical impedance spectroscopy to study the self-healing properties of protective coatings. Electrochemistry Communications, v. 9, n. 10, p. 2622-2628, out. 2007.

ZHELUDKEVICH, M.L., SHCHUKIN, D.G., YASAKAU, K.A., MÖHWALD, H., FERREIRA, M.G.S. Anticorrosion coatings with self-healing effect based on nanocontainers impregnated with corrosion inhibitor 2007 Chemistry of Materials 19 (3), pp. 402-411. 